
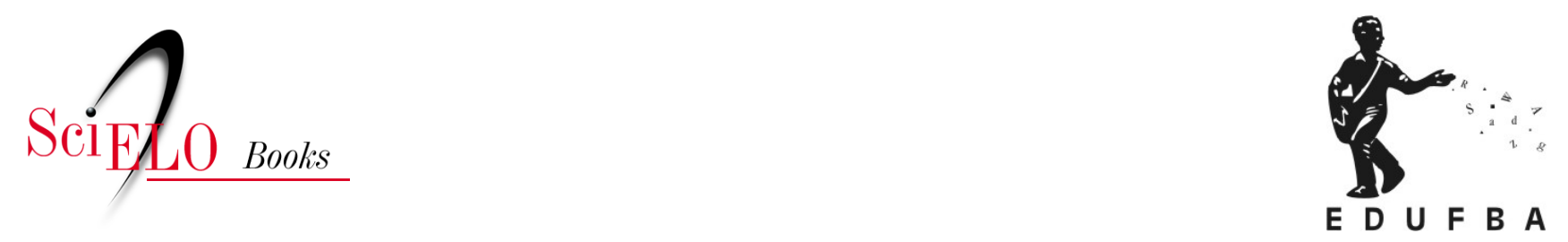

\title{
Relações de poder e Trabalho Infantil Doméstico nas perspectivas dos media e das trabalhadoras
}

\author{
Danila Gentil Rodriguez Cal
}

\section{SciELO Books / SciELO Livros / SciELO Libros}

CAL, D.G.R. Relações de poder e Trabalho Infantil Doméstico nas perspectivas dos media e das trabalhadoras. In: Comunicação e trabalho infantil doméstico: política, poder, resistências [online]. Salvador: EDUFBA, 2016, pp. 149-308. ISBN: 978-85-232-1870-6.

https://doi.org/10.7476/9788523218706.0008.

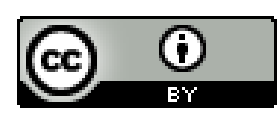

All the contents of this work, except where otherwise noted, is licensed under a Creative Commons Attribution $\underline{4.0 \text { International license. }}$

Todo o conteúdo deste trabalho, exceto quando houver ressalva, é publicado sob a licença Creative Commons Atribição 4.0. 


\section{Relações de poder e Trabalho Infantil Doméstico nas perspectivas dos media e das trabalhadoras}

Neste capítulo, apresentaremos inicialmente o desdobramento metodológico mais refinado da nossa pesquisa a partir do detalhamento das categorias analíticas e das marcas textuais que utilizamos como diretrizes para identificação e análise das relações de poder tanto nos textos dos media quanto nas falas das entrevistadas. Em seguida, abordaremos alguns aspectos gerais da cobertura midiática sobre o TID para posteriormente desenvolvermos a apreciação do corpus.

A análise é apresentada pela identificação e exame das relações de poder (power over, power to e power with) tal como mobilizadas e construídas nos media e nos grupos focais, a partir de três tópicos distintos: (a) Definições acerca do TID; (b) Vivências no TID (com destaque para as temáticas "violência" e "educação") e (c) Projeções de futuro e responsabilidades (o que inclui a discussão 
sobre as perspectivas de futuro das meninas e mulheres envolvidas e sobre as responsabilidades pelo TID).

Apesar de abordarmos dois contextos comunicativos distintos (media e grupos focais), avaliamos que seria mais profícuo, do ponto de vista analítico, investigar esses âmbitos conjuntamente. Assim, faremos, de modo paralelo e sequencial, o exame do desdobramento de uma mesma temática tanto nos media quanto nos grupos focais, procurando não perder de vista características que são próprias de cada um. Por exemplo, os textos dos media possuem um encadeamento interno e recursos de edição (títulos, subtítulos etc.), o que facilita a identificação das temáticas desenvolvidas. Por outro lado, nos grupos focais entendemos que é da própria dinâmica desse momento o desdobramento da discussão de modo não linear e, frequentemente, com sobreposição de assuntos. Dessa forma, uma mesma discussão pode trazer elementos para a apreciação de distintas temáticas.

\section{CATEGORIAS ANALÍTICAS}

Para organizar o processo de investigação de nosso material empírico, composto de matérias jornalísticas e de discursos de trabalhadoras e ex-trabalhadoras infantis domésticas, realizamos cinco movimentos analíticos:

1) Observação sistemática e contínua do material disponível, a fim de evidenciar temáticas norteadoras;

2) Identificação de relações de power over, power to e power with nos textos dos jornais e nas interações nos grupos focais;

3) Exame do modo como meninas e mulheres afetadas pelo TID são posicionadas e se posicionam na teia de relações de poder que envolve o assunto;

4) Investigação de como os sentidos em torno do TID alimentam e são alimentados por relações de poder;

5) Análise de como os posicionamentos dos sujeitos e as significações culturais reverberam na configuração política do TID a partir dos próprios envolvidos. 
Assim, inicialmente, realizamos a organização e leitura sistemática de todo material empírico. A partir desse investimento e da revisão de literatura acerca do TID, evidenciamos a proeminência de seis temáticas principais, conforme descrevemos acima: o que é o TID; educação; responsabilidade pelo o TID; violência; trabalho doméstico em casa e na casa da patroa; perspectivas de futuro. Em seguida, esses temas foram, então, agrupados em torno de três categorias principais: a) Definições acerca do TID; (b) Vivências no TID e (c) Projeções de futuro.

Analisar “definições acerca do TID” e investigar os modos como se nomeia essa prática dizem, em primeira instância, das relações de poder que ela envolve. É bastante distinto, afinal, conceituá-la como "trabalho infantil doméstico" ou como "reparar menino" ou, ainda,"varrer uma casa”, por exemplo. Outro elemento que torna complexa essa conceituação é a tensão entre o trabalho realizado na própria família e o realizado na casa de terceiros. Frequentemente, o primeiro não é caracterizado como uma forma de trabalho infantil.

As principais vivências atribuídas ao TID nos discursos dos media e das afetadas estavam relacionadas às temáticas da violência e da educação. Nesse sentido, analisar a temática da "violência” significa examinar a relação estabelecida pelos media entre TID e violência e o modo como meninas e mulheres afetadas mobilizam e constroem sentidos sobre a dominação, a resistência e a solidariedade acerca desse assunto. A temática da "educação", além de ser a segunda mais citada nos jornais, fornece elementos para discussão das relações de poder no TID porque é recorrentemente identificada como a área mais afetada por esse tipo de prática, ao mesmo tempo em que há discussões entre as entrevistadas acerca das razões pelas quais não obtiveram sucesso na escola.

Por fim, examinar as “projeções de futuro” permite que investiguemos o horizonte de possibilidades colocado para (e por) esses sujeitos, ao mesmo tempo em que devem ser discutidos os constrangimentos e as reais possibilidades de perseguição de projetos de vida. De modo complementar, possibilita também analisar as "responsabilidades" que são atribuídas, reconhecidas e legitimadas no TID e elucida a forma pela qual relações de poder atuam na configuração política dessa atividade.

Para cada uma dessas categorias, realizamos um estudo comparativo entre as perspectivas dos media e as das afetadas. A identificação das relações de poder nos textos e nas falas das entrevistadas foi feita de modo reflexivo em inte- 
ração com as conceituações discutidas no terceiro capítulo. Consideramos, na construção das categorias analíticas, ideias e posicionamentos que emergiram do estudo sistemático do material empírico, os quais foram iluminados a partir dos pressupostos teóricos dos quais partimos. Portanto, não se tratou de imputar ao nosso corpus categorias externamente impostas, mas sim de identificá-las por meio um processo complexo e reflexivo entre as revelações do empírico e as contribuições da teoria.

Desse processo de reconhecimento do corpus, resultou um quadro indicativo de marcas identificáveis das relações de poder nos textos dos media e nos grupos focais. Consideramos essas marcas textuais indícios concretos possíveis de serem encontrados nos materiais analisados. Assim, cada uma das relações de poder evidenciada tanto nos media quanto nos grupos focais "conscientemente ou não, deixará 'marcas', que poderão ser reconhecidas, mapeadas e classificadas”. (SILVA; MARTINS, 2009, p. 6) A partir disso, ensaiamos uma lista indicativa (e, portanto, não definitiva) de possíveis marcas para identificação e análise de relações de poder nos textos dos media e nas discussões nos grupos focais, apresentadas no quadro a seguir (Quadro 1).

Após a identificação de preponderâncias em cada uma das três temáticas, procedemos à análise por meio dos seguintes parâmetros, inspirados no esquema metodológico geral de Allen (2000): (A) o posicionamento dos sujeitos; (B) as significações culturais e (C) as práticas sociais.

(A) O "posicionamento de meninas e mulheres" envolvidas com o TID se relaciona com os lugares que são atribuídos aos sujeitos, ao modo, portanto, como eles são dispostos em uma teia de relações de poder. Com a finalidade de investigar essas posições nos textos dos media e nas falas das afetadas, construímos uma tabela indicativa baseada em Wright (1995), que pesquisou em livros de criminologia das décadas de 1950, 1960, 1980 e 1990 como mulheres eram consideradas nos tópicos relacionados a gênero.

Wright fundamentou seu trabalho em investigações acerca da imagem da mulher em propagandas e recorreu a Goffman, sobretudo em Gender Advertisement, para examinar se os autores retratam mulheres "como passivas e submissas 'vítimas' da opressão, ou como agentes intencionais 'preparados para a ação social', que podem usar os seus recursos individuais e coletivos como 'resistentes"”. (WRIGHT, 1995, p. 113, tradução nossa, grifo do autor) Para análise dos textos, Wright (1995, p. 113) elaborou três categorias: (1) “vítimas”: nas quais as mulheres 


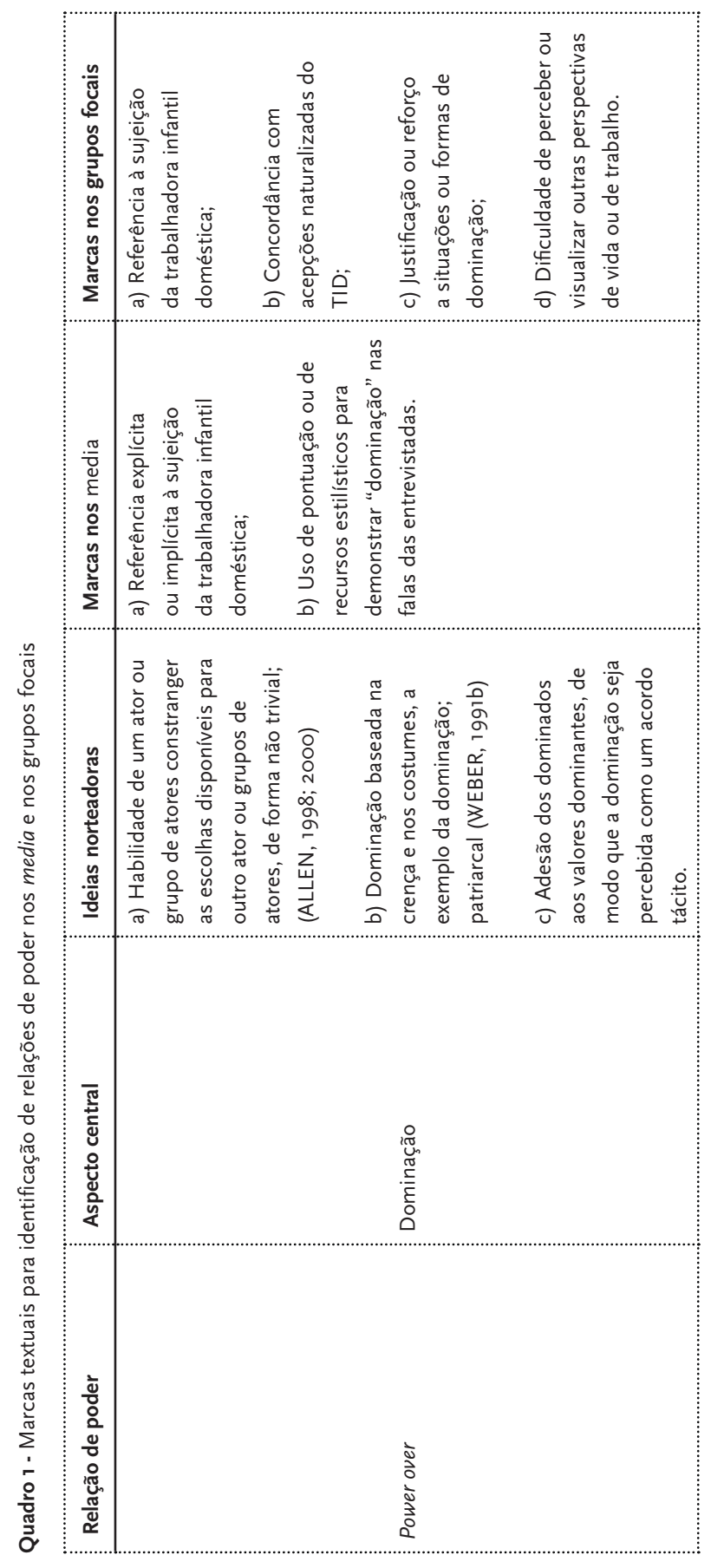




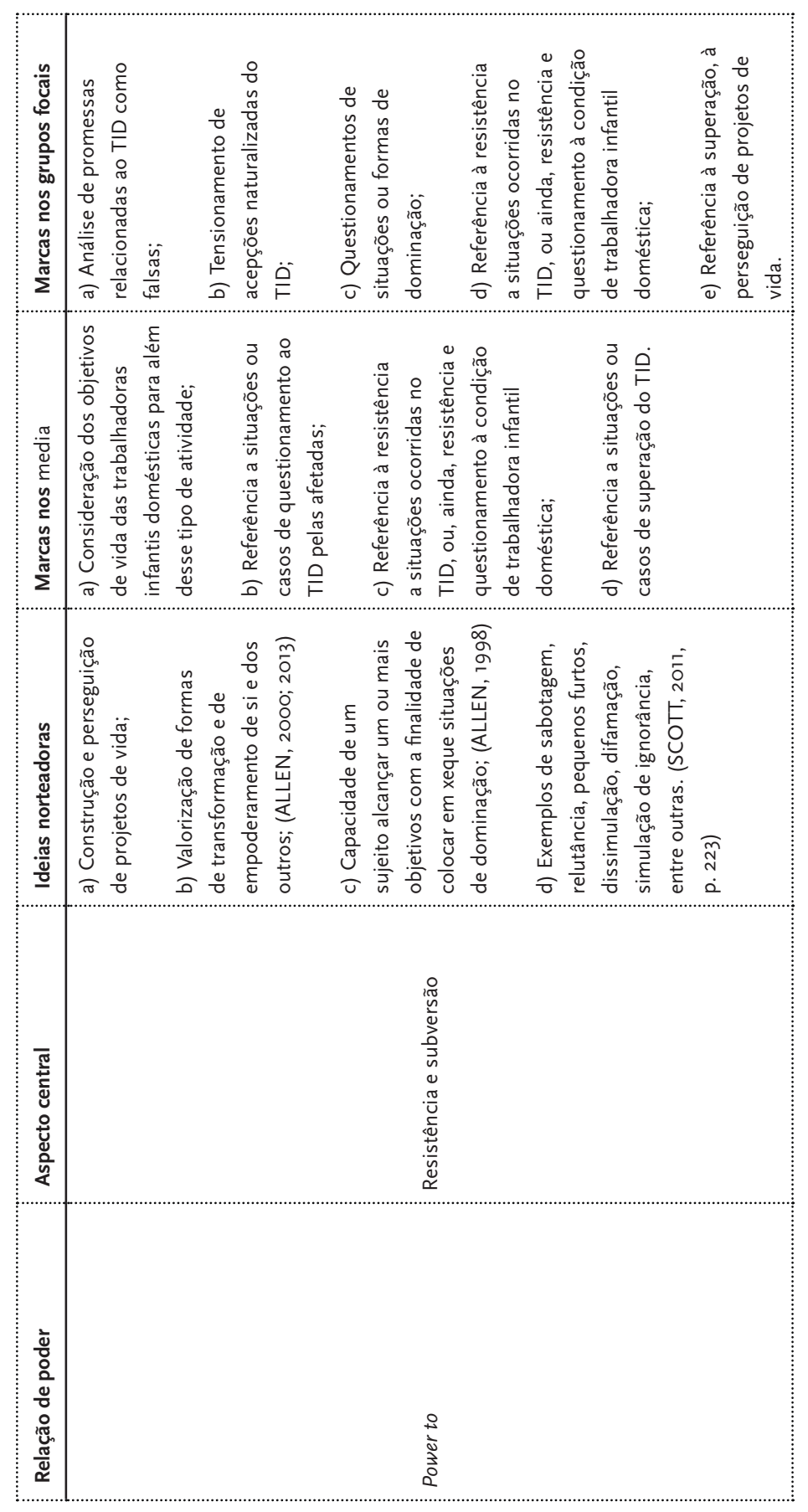

154 | COMUNICAÇÃO E TRABALHO INFANTIL DOMÉSTICO 


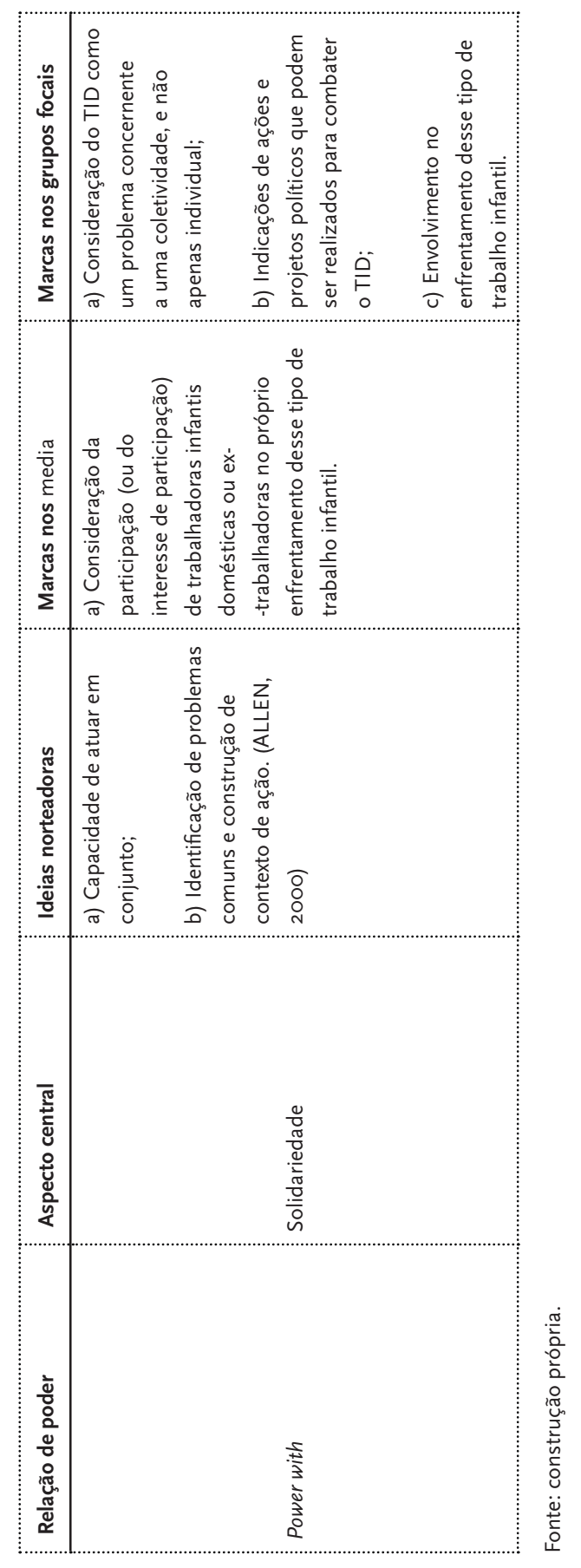


são tematizadas como vítimas de exploração, opressão ou são subjugadas pelos homens, porém sem indicação de ações que podem empreender para lutar; (2) "resistentes": quando o autor ressalta as possibilidades e a capacidade de as mulheres lutarem contra situações opressivas e, por fim, (3) "nenhum tema", quando os assuntos relacionados à dominação de gênero não são tratados pelo autor.

De acordo com a abordagem que estamos trabalhando, analisar relações de poder pressupõe a compreensão de como elas atuam na constituição de lugares dos (ou para os) sujeitos no mundo. (ALLEN, 2000) Nesse sentido, há uma tensão entre a agência individual e estruturas mais amplas que agem na conformação dessas posições. Sobre esse assunto, ao comentar uma resenha crítica do livro Frame Analysis, Goffman (1981) ressalta que:

\footnotetext{
[...] não é que não se deva ver que são pessoas com biografias únicas interagindo, mas que se deve avançar deste fato confortável para tentar desvelar as principais razões pelas quais é atribuído lugar a essas histórias pessoais e o quadro de entendimentos normativos que isso implica, o que, naturalmente, traz-nos de volta a padrões e estruturas. (GOFFMAN, 1981, p. 62, tradução nossa)
}

O autor chama atenção para o caráter situado da atribuição desses lugares aos sujeitos e informa a necessidade de a investigação procurar alcançar elementos de fundo, a partir dos quais seria possível esclarecer como esses posicionamentos são construídos. Dessa forma, tomamos com inspiração o modelo proposto por Wright (1995) para identificar o cerne dos posicionamentos com o objetivo de avaliar tendências nos textos dos media e nas falas das entrevistadas.

Consideramos, ainda, a ressalva feita por Goffman, na medida em que relacionamos esses posicionamentos a noções de poder, buscamos identificar como esses padrões mais amplos atuam na constituição de posições para os sujeitos. Contudo, procuramos tomar o cuidado de não essencializar esses indivíduos e partimos do entendimento de que são sujeitos que travam complexas relações entre agência e estruturas. (BIROLI, 2013; ALLEN, 2000)

Elaboramos, então, um segundo quadro (Quadro 2) com indicações para permitir a identificação de diferentes posicionamentos acerca de meninas e mulheres afetadas pelo TID. A partir das relações de poder que estamos considerando, acreditamos, em princípio, que três lugares principais poderiam ser atribuídos a 


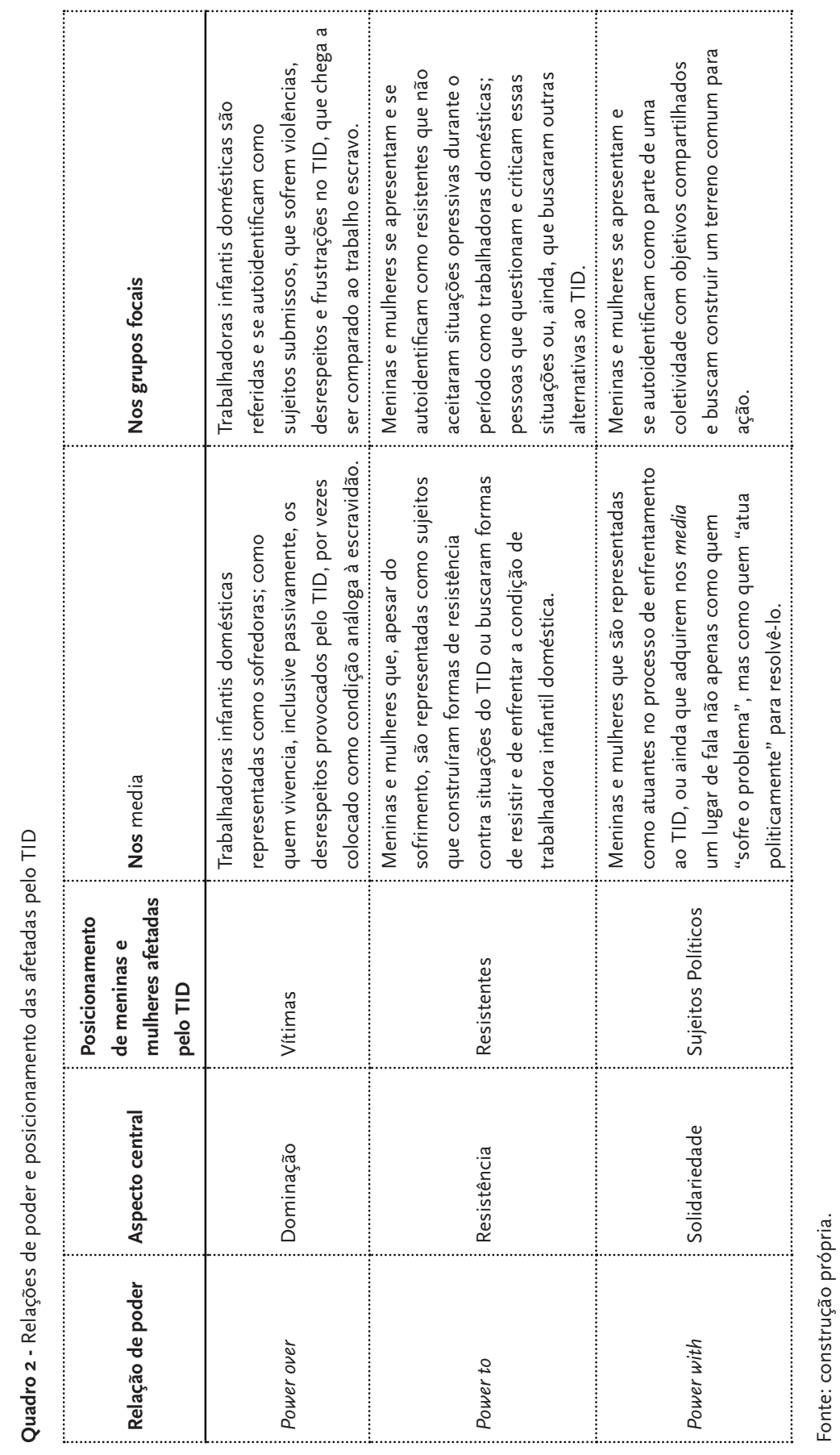


esses sujeitos: "vítimas"; "resistentes ou subversivas" e "sujeitos com capacidade de ação política”. ${ }^{1}$

Consideramos o posicionamento preponderante de "vítimas" quando os textos se referem a atuais ou antigas trabalhadoras infantis domésticas como sujeitos que sofrem (maus-tratos, humilhações, violências, prejuízos afetivos e sociais) por exercerem esse tipo de atividade e que precisam da ajuda ou da intervenção dos outros para conseguirem melhores condições de vida. Por "resistentes”, consideramos as referências a contestações desse tipo de situação por meninas e mulheres afetadas pelo TID e quando eram relatados casos de superação da condição de trabalhadora infantil doméstica, apesar das adversidades. A atribuição do posicionamento como "sujeitos políticos" está condicionada à manifestação de um papel ativo dessas mulheres na construção de objetivos compartilhados e de uma base comum para ação contra o TID.

(B) Em seguida ao exame dos posicionamentos desses sujeitos nos discursos, observamos de modo mais abrangente como as relações de poder atuavam na “constituição de significações culturais” sobre o TID. A partir desses referenciais, investigamos, no interior de cada uma das seis temáticas discutidas, como os sentidos em torno do TID alimentam e são alimentados por relações de poder.

(C) O último passo analítico consistiu no exame acerca de como os posicionamentos dos sujeitos e as significações culturais reverberam na "configuração política do TID” a partir dos próprios envolvidos. Nossa premissa é a de que, por meio dos discursos, é possível apreender práticas sociais e políticas. De acordo com França e Guimarães (2006):

A vida social é marcada pela luta pelo poder, pela diferença, pela presença de contradições, de antagonismos - que têm uma existência objetiva, no plano das práticas, das intervenções e apropriações no mundo, mas encontram no campo da linguagem e do simbólico lugar privilegiado de expressão. Por outro lado, os grandes sistemas simbólicos, os valores, os quadros de sentido existem somente em situações concretas - nas práticas comunicativas, na materialização simbólica operada pelo discurso. (GUIMARÃES; FRANÇA, 2006, p. 97)

1 Faremos referência a esse terceiro tipo como "sujeitos políticos". Não queremos diminuir, com isso, o papel político de "vítimas" e "resistentes", mas apenas ressaltar, nessa última categoria, a possibilidade de atuação voltada para a construção de solidariedade e power with entre trabalhadoras infantis domésticas. 
Dessa forma, analisar discursos também significa analisar práticas, na medida em que é por meio dos primeiros que as últimas ganham sentido e expressão. Essa perspectiva também é compartilhada por Wodak $(2001,2012)$ e Fairclough $(2001,2013)$, que defendem, como discutimos no capítulo anterior, a ideia de que os discursos devem ser entendidos como práticas sociais. Segundo Fairclough, Mulderring e Wodak (2011), esse ponto de vista sugere uma relação dialética entre discursos e o contexto social que os enquadra. Trata-se, portanto, de uma relação em dois sentidos: "o evento discursivo é conformado pelas situações, instituições e estruturas sociais, mas também os conforma”. (FAIRCLOUGH; MULDERRING; WODAK, 2011, p. 357) Assim, o foco nas práticas sociais permite, de acordo com Fairclough (2001), articular a perspectiva das estruturas, ou dos contextos mais amplos que sustentam padrões opressivos, com as possibilidades de ação e de transformação social. Esse modo de entender articulação entre discursos e práticas é pertinente para a investigação que estamos desenvolvendo porque considera as relações de poder que atuam na construção de discursos, mas reconhece o potencial transformativo de práticas sociais por meio também dos discursos.

Após a observação sistemática do material da pesquisa e da incursão na literatura a respeito de poder e de TID, elencamos quatro práticas principais que, pressupomos, contribuem para compreendermos como o jogo das relações de poder atua na configuração política do TID. São elas: a) aceitação; b) resistência ou subversão; c) demonstração da injustiça; d) luta política a partir dos próprios afetados.

Consideramos como ponto de partida, a "aceitação", em que relações de power over atuariam principalmente no sentido de gerar conformismo e resignação, como largamente trabalhado na literatura sobre esse tipo de trabalho infantil, tal qual discutimos no primeiro capítulo. A segunda prática é a "resistência", em que as relações de dominação são problematizadas e desafiadas por práticas de questionamento, ou mesmo subversivas, mas que não têm como finalidade mudar a situação do TID, e sim aprimorar condições mais imediatas de trabalho, como enfrentar o poder de "mando" do patrão.

Por "demonstração da injustiça", compreendemos práticas de reflexão e questionamento do TID por meio da demonstração das violações de direitos e dos prejuízos que esse tipo de trabalho causou ou vem causando a meninas, porém não no sentido da vitimização, e sim no da tematização desses aspectos como injustiças. É quando os desrespeitos vivenciados pelas trabalhadoras in- 
fantis domésticas são problematizados como injustiças. A respeito da "luta política a partir dos afetados”, compreendemos a atuação política no sentido da construção de um processo de ação coletiva de enfrentamento ao TID. Trata-se de discursos que não apenas tematizam injustiças relacionadas a esse tipo de trabalho infantil, mas também convocam à ação e à percepção de que se trata de um problema coletivo e não individual.

Como pano de fundo dessas quatro práticas destacadas, está a atuação de organizações de advocacy contra o TID, o que, a nosso ver, sedimenta um rico terreno de possibilidades e tensões entre a construção do TID como um problema público por meio de ações de advocacy e as práticas políticas de meninas e mulheres diretamente afetadas. Acreditamos que uma divisão dessa natureza nos permitirá compreender de modo nuançado como ocorrem as práticas políticas de meninas e mulheres envolvidas no TID.

Nas próximas seções, apresentaremos alguns aspectos gerais da cobertura midiática e realizaremos a análise dos materiais dos media e dos grupos focais de modo comparativo acerca das três categorias destacadas: (a) Definições acerca do TID; (b) Vivências no TID e (c) Projeções de futuro e Responsabilidades.

\section{ASPECTOS GERAIS DA COBERTURA MIDIÁTICA}

De acordo com o que apresentamos no capítulo anterior, focamos essa parte da pesquisa em 136 matérias publicadas nos jornais O Liberal e Diário do Pará. Por meio de análise de conteúdo, obtivemos alguns resultados gerais que avaliamos pertinentes para nossa investigação, os quais serão discutidos nesta seção.

Em relação às fontes consultadas, o percentual mais alto foi para representantes da sociedade civil, o que correspondeu a 37,1\% do total de informantes. Ao especificarmos as fontes ligadas à sociedade civil, percebemos que a consulta a agentes diretamente vinculados ao Petid e ao Cedeca-Emaús teve destaque $(53,1 \%)$, seguidos por organismos internacionais parceiros do Programa, como OIT e Unicef (30,6\%). Como contraponto, representantes dos sindicatos ligados ao trabalho doméstico foram consultados apenas em três momentos, o que correspondeu a um percentual de 3,1\% dentro do grupo de fontes da sociedade civil.

Meninas e pais de atuais e antigas trabalhadoras domésticas corresponderam a $17,4 \%$ de todos os entrevistados. A maior parte das atuais trabalhadoras infantis entrevistadas não participava do Petid (85,7\%), enquanto que do total 
de ex-trabalhadoras ouvidas, a proporção foi: 62,1\% para atendidas e 34,5\% para não atendidas por programas de enfrentamento ao TID. ${ }^{2}$

Tabela 2 - Principais fontes ouvidas nas matérias $^{3}$

\begin{tabular}{|c|c|c|c|c|}
\hline Grupos de fontes & Fontes & $\begin{array}{l}\text { Quantidade de } \\
\text { inserções }\end{array}$ & $\begin{array}{l}\% \text { dentro } \\
\text { do grupo }\end{array}$ & $\begin{array}{l}\% \text { da } \\
\text { categoria }\end{array}$ \\
\hline \multirow{7}{*}{$\begin{array}{l}\text { Representantes da } \\
\text { Sociedade Civil }\end{array}$} & Petid e/ou Cedeca-Emaús & 52 & 53,1 & \multirow{7}{*}{37,1} \\
\hline & $\begin{array}{l}\text { Organismos Internacionais (OIT, } \\
\text { Unicef) }\end{array}$ & 30 & 30,6 & \\
\hline & $\begin{array}{l}\text { Organizações sociais que enfrentam } \\
\text { o TID (sem Petid ou Cedeca-Emaús); }\end{array}$ & 6 & 6,1 & \\
\hline & $\begin{array}{l}\text { Fóruns e ONGs articuladoras de } \\
\text { diversas organizações }\end{array}$ & 3 & 3,1 & \\
\hline & $\begin{array}{l}\text { Sindicatos dos Trabalhadores } \\
\text { Domésticos }\end{array}$ & 3 & 3,1 & \\
\hline & ONGs em geral & 1 & 1,0 & \\
\hline & $\begin{array}{l}\text { Entidade de Classe: Ordem dos } \\
\text { Advogados do Brasil (OAB) }\end{array}$ & 3 & 3,1 & \\
\hline \multirow{3}{*}{ Afetados } & Ex-trabalhadoras infantis domésticas & 29 & 63,0 & \multirow{3}{*}{17,4} \\
\hline & Trabalhadoras infantis domésticas & 7 & 15,2 & \\
\hline & $\begin{array}{l}\text { Pais de atuais ou de ex-trabalhadoras } \\
\text { infantis domésticas }\end{array}$ & 10 & 21,7 & \\
\hline \multirow{3}{*}{$\begin{array}{l}\text { Representantes do } \\
\text { aparato estatal }\end{array}$} & Segurança Pública & 7 & 16,7 & \multirow{3}{*}{15,9} \\
\hline & $\begin{array}{l}\text { Ministério Público e Ministério } \\
\text { Público do Trabalho }\end{array}$ & 14 & 33,3 & \\
\hline & $\begin{array}{l}\text { Representantes do poder Executivo } \\
\text { (federal, estadual ou municipal) }\end{array}$ & 21 & 50,0 & \\
\hline Especialistas & $\begin{array}{l}\text { Pesquisadores, sociólogos, } \\
\text { antropólogos e advogados }\end{array}$ & 34 & 100 & 12,9 \\
\hline \multicolumn{2}{|l|}{ TOTAL } & 220 & & $83,3^{3}$ \\
\hline
\end{tabular}

Fonte: Dados da pesquisa.

2 Em 3,4\% não foi possível identificar.

3 Os $16,7 \%$ restantes referem-se a: empregadores (2,7\%); representantes de associações empresariais $(1,5 \%)$; jornalistas $(1,5 \%)$; cidadãos comuns $(3,8 \%)$; representantes do judiciário $(1,1 \%)$ e outros $(6,1 \%)$. 
Em princípio, esses dados demonstram um espaço significativo dentre o total de fontes consultadas para as afetadas, de modo a possibilitar a "autoexpressão dos oprimidos” nos media (MIGUEL, 2011), tal como discutimos no segundo capítulo. Contudo, a expressão de representantes de organizações sociais e especialistas é muito superior (50\%), o que reforça a ideia, desenvolvida no mesmo capítulo, de que, em relação a assuntos que envolvem crianças e adolescentes, há predominância das vozes de especialistas e de representantes de organizações sociais considerados, por vezes, quem têm condições mais adequadas de avaliar o que seriam os melhores interesses de meninos e meninas. (MIGUEL, 2011; EARLS, 2011) É necessário ainda investigar os contextos nos quais são dados espaço e voz a crianças e a adolescentes nas matérias.

A respeito das temáticas investigadas, identificamos em 33,3\% das matérias a abordagem de dois ou mais temas ${ }^{4}$ e, em boa parte delas, eles se complementavam. Por exemplo, ao explicar o que é o TID, os textos e suas fontes normalmente o relacionavam a prejuízos educacionais ou violências. Ou, então, ao tematizar as responsabilidades acerca do TID, fazia-se, em alguma medida, a discussão sobre as perspectivas de futuro das meninas diretamente afetadas. Ou, ainda, matérias do Caso Marielma, a menina de 11 anos que fora assassinada pelos patrões, poderiam remeter à discussão sobre violência nesse tipo de trabalho infantil. Todavia, foi possível perceber as temáticas principais trabalhadas no material investigado, como apresentado no Gráfico 2.

Quanto ao modo como meninas e mulheres afetadas pelo TID foram discursivamente posicionadas nas matérias, a predominância é para a categoria de "vítima”, com 63,5\% do total, seguida por "resistente”, com 11,5\%, e "sujeito político”, com 5,1\%. Não foi possível identificar essa variável quando as matérias não ouviam esse público ou não tratavam diretamente dele (19,9\%). Relevante ressaltar que uma mesma matéria pode ter apresentado até duas maneiras diferentes de abordar meninas e mulheres atuais e ex-trabalhadoras infantis domésticas, de tal forma que totalizamos 156 posicionamentos em 136 textos jornalísticos.

As informações ora mostradas, entretanto, contam-nos apenas uma parte da história. Como o objetivo de lançar olhar minucioso a essa questão, nas pró-

4 Das matérias investigadas, $84(66,7 \%)$ abordaram principalmente uma única temática relacionada ao TID, 29 (23\%) abordaram duas temáticas e 13 (10,3\%) mais de três. Em 10 matérias não foi possível identificar essas temáticas. 
ximas seções investigaremos como cada uma daquelas temáticas e daqueles posicionamentos foram desenvolvidas tanto nos media quanto nos grupos focais.

Gráfico 2 - Recorrências das principais temáticas trabalhadas nas matérias sobre o TID por número de matérias

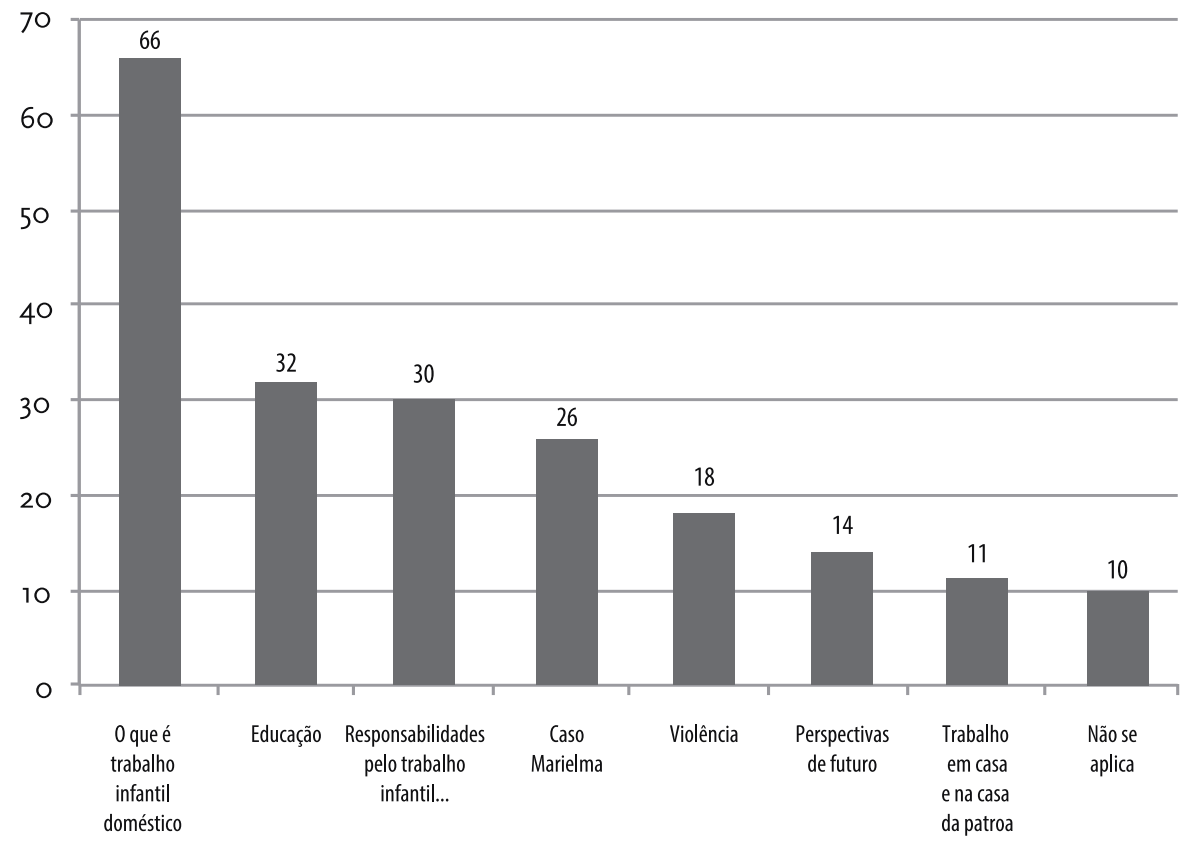

Fonte: Dados da pesquisa $(n=207) \cdot{ }^{5}$

\section{DEFINIÇÕES ACERCA DO TID}

A temática acerca do que era o TID foi a predominante nos jornais $(31,9 \%$ do total). A nosso ver, a principal justificativa para esse dado é a de que a própria definição do que era o "trabalho infantil doméstico" consistia em um campo de disputas. Por um lado, entendimentos largamente compartilhados de que não se tratava de uma atividade laboral, e sim de uma espécie de ajuda mútua, enquan-

5 A categoria "não se aplica" refere-se a matérias que tinham o trabalho infantil como tema principal, porém informavam sobre o lançamento de radionovelas acerca do assunto, ou ainda, sobre a assinatura de termos de parceria entre o empresariado local e o Petid. 
to pelo outro tínhamos um grupo de organizações engajado no enfrentamento desse tipo de trabalho infantil, que o considerava um sério problema social e político. Assim, do ponto de vista dessas organizações, era necessário explicar publicamente em que consistia, afinal, o "trabalho infantil doméstico" e as razões para combatê-lo.

Um primeiro modo de os jornais publicizarem o TID foi a divulgação de dados estatísticos acerca da situação de crianças e adolescentes trabalhadores domésticos no Brasil. Estudos da OIT, do Cedeca-Emaús e do Departamento Intersindical de Estatística e Estudos Socioeconômicos (Dieese) ganharam repercussão nos jornais. Foram matérias sobre a divulgação de dados, mas que ampliaram seu escopo com a inscrição de personagens de modo contextualizado ao tema, como no trecho abaixo, que abre uma matéria sobre a pesquisa "Trabalho Doméstico de Meninas em Belém”, do Cedeca-Emaús:

A adolescente S. S. L. 15 anos, natural de Igarapé-Miri, desde os 12 anos de idade trabalha em casa de família, cuidando de crianças e ainda ajuda nos afazeres domésticos. Ela estuda a $6^{\mathrm{a}}$ série do Ensino Fundamental e sonha cursar uma universidade de advocacia. Apesar de manter vínculo com a sua família, diz ter um bom relacionamento com a sua atual patroa, tanto que já afirma fazer parte da família com quem mora. Perto de muitas que são obrigadas a trabalhar para o seu sustento e, na maioria das vezes, da própria família, essa menina é uma exceção em relação a milhares de meninas que servem de mão de obra doméstica no Pará. A consequência disso é a violação de todos os seus direitos como cidadão [sic], seja física, seja moral. (DIÁRIO DO PARÁ, 10/02/2001, grifo nosso)

O texto mostra ambiguidades a respeito do entendimento do que seja o TID e sobre o que especificamente está sendo combatido. Considerar-se alguém da família é colocado como um aspecto positivo que destaca a personagem como uma exceção entre outras que exercem essa atividade no estado. Não há clareza em relação ao que diferencia a personagem S. S. L. da exploração do TID abordada no restante da matéria, que ressalta os achados da pesquisa relativos a violações dos direitos à convivência familiar e comunitária com a saída dessas meninas de municípios do interior para Belém, e ainda o atraso escolar a que estão submetidas em razão da ampla jornada de trabalho. 
Quanto ao posicionamento da adolescente acerca do TID, ela é apresentada como "resistente" na medida em que seria uma "exceção" dentre meninas que são "exploradas" no serviço doméstico e por estar perseguindo um projeto de vida: "tornar-se advogada". Entretanto, os mesmos motivos pelos quais ela é tida como "resistente" reforçam situações de opressão relacionadas ao TID (atraso escolar, ambiguidade acerca de pertencer àquela família, perda do convívio familiar). A menina S. S. L. é inscrita naquela história na qual a exceção confirma uma regra. E a regra do TID seria a condição de dominação a qual essas meninas estão submetidas, tendo todos os seus direitos violados.

Essa reportagem é exemplar em relação à cobertura dos primeiros anos de enfrentamento ao TID, quando imprensa e sociedade estavam tendo os primeiros contatos com a problematização dessa prática. A postura do jornal reforça o posicionamento diplomático dos primeiros anos do Petid (CAL, 2007), observado nas peças das primeiras campanhas de publicidade do Programa. Como apresentamos no segundo capítulo, o objetivo do Petid era estabelecer um cuidadoso diálogo com a cultura local para não provocar reações fortes em defesa do TID. A repercussão dessa postura na matéria em tela fica ainda mais clara quando observamos a chamada de primeira página: "Domésticas, entre o céu e o inferno. Elas vêm do interior do Estado, geralmente, aos 10 e 12 anos, para cuidar de crianças e ajudar nos afazeres domésticos. Muitas são bem tratadas, mas outras vivem literalmente em regime de escravidão”. (DIÁRIO DO PARÁ, $1^{a}$ página, 10/02/2001, grifo nosso)

Portanto, apesar de relatar malefícios desse tipo de trabalho infantil, o próprio discurso do jornal afirma que há meninas que são bem tratadas e outras não, o que abre margem ao entendimento de que o TID é possível, desde que não haja exploração. Apesar disso, quando essa exploração era tematizada, fazia-se, de modo recorrente, analogia à escravidão, como no trecho discutido acima.

A conceituação do TID como escravidão, ou ainda violação de direitos da criança e do adolescente, é reforçada em outras matérias que enfocam as situações de trabalho e os dramas vividos por meninas que exercem essa atividade. Por meio do relato de histórias de vida e dos proferimentos de atores sociais ou especialistas, são ressaltadas as longas jornadas, os escassos tempo de folga e ainda as falsas promessas relacionadas à quantidade e aos tipos de tarefas que seriam exercidas. Distintas nuances da relação de poder como power over são, então, apresentadas, e as meninas discursivamente posicionadas como sujeitos que sofrem com a dominação exercida pelos patrões: 
F.R. começou a trabalhar como babá aos 10 anos. A partir das dicas de uma amiga, a menina foi cuidar de uma criança de dois anos durante três dias na semana. [...] No início, por $\mathrm{R} \$ 50$ [mensais] ${ }^{6}$, a menina deveria "reparar" o bebê. Após duas semanas, sua patroa passou a exigir trabalho diário. A menina parou de estudar e virou empregada doméstica: lavava, passava, limpava a casa. O trabalho consumia todo o seu dia. (O LIBERAL, 05/03/2002, grifo nosso)

Aquela ambiguidade inicial acerca do que consistia o TID, observada na matéria citada anteriormente, começa a ser substituída a partir de 2002 por um questionamento mais explícito dessa prática e das violações de direitos a que ela envolve. Essa mudança no modo como o discurso sobre esse tipo de trabalho infantil vinha sendo construído nos media analisados é perceptível, entre outros fatores, pelo uso de aspas na palavra “reparar”. Há, portanto, um juízo de valor acerca da forma como a adolescente relata o início nessa atividade. É como se fosse o registro do engodo, da promessa falsa, na medida em que "reparar criança” é considerado algo de menor esforço, fácil de ser realizado, e não uma relação de trabalho propriamente. Porém, as consequências disso são conhecidas: a menina abandonou os estudos e foi acumulando cada vez mais responsabilidades em relação ao cuidado com a casa.

Na narrativa construída pelo jornal sobre a menina trabalhadora doméstica F. R., coexistem dois níveis distintos de power over. Em primeiro plano, podemos entender a situação apresentada como uma relação de power over próxima à conceituação unidimensional do poder, em que há um conflito de interesses observável de tal modo que ação de um ator faz com que o outro faça algo que de outra forma não faria. (DAHL, 1957) Nesse contexto, as ações da patroa, ao exigir trabalho diário, constrangeram as escolhas e limitaram as oportunidades de estudo da criança. Consequentemente, as possibilidades de empoderamento desse sujeito são diminuídas diante de uma condição descrita como incapacitante tanto em termos de ação quanto de expressão.

Num segundo plano analítico, observa-se a denúncia ao componente ideológico do TID. A partir do referencial teórico de Lukes (2005), consideramos que o modo como o jornal narra a história da personagem desvela uma relação de

6 O salário mínimo nessa época era de $\mathrm{R} \$ 200,00$. 
power over latente, na qual a relação de dominação é subjacente ao discurso da própria menina afetada, na medida em que o verbo "reparar", utilizado para descrever a atividade que realizava na casa da patroa, foi grafado com o uso de aspas. De certa forma, o jornal denuncia que escapa à menina doméstica a percepção de que a atividade de "reparar o menino" é um trabalho, nesse caso, objeto de exploração. De acordo com Lukes (2005), a efetividade desse tipo de power over reside no fato de ele ser pouco observável para quem sofre. Assim, a menina F. R. é descrita como "vítima” que sofre um processo de dominação ideológico e, portanto, latente.

Outro modo pelo qual relações de power over foram mobilizadas pelos jornais articula-se com a perspectiva de Allen (1998, 2000), segundo a qual "dominação" refere-se à capacidade de restringir, de modo não trivial, as escolhas desses indivíduos afetados. Como na definição de Foucault (1995), trata-se de uma ação sobre ações possíveis. Ou ainda de uma ação limitadora das possibilidades de ação do outro. A matéria "Adolescente tem os direitos violados" apresenta um exemplo dessa nuance de power over

A menina L.S., de apenas 14 anos, é um exemplo típico de trabalhadora infantil doméstica que apresenta uma série de direitos violados. L. S. trabalha num apartamento no bairro da Pedreira há nove meses. Parou de estudar na $5^{\mathrm{a}}$ série do ensino fundamental, ganha $\mathrm{R} \$ 150$ mensais, fica com $\mathrm{R} \$ 100$ e leva o restante para sua mãe que vive no município de Moju, em uma das duas folgas que tem por mês.

'Faz tempo que não falo com meus pais, pois ela (patroa) não deixa eu fazer ligação, só se acontecer algo com o bebê’. Ela conta que quando sua patroa a pediu para sua tia, que mora em Belém, disse que era apenas para cuidar de um bebê. Quando ela chegou na casa percebeu que faria as demais tarefas domésticas. [...] L.S. disse que não está estudando porque a patroa 'não quer menina que estude por causa do bebê'. (O LIBERAL, 15/03/2002)

Apesar de receber dinheiro como pagamento e de esse valor ser relativamente próximo ao salário mínimo vigente na época ( $\mathrm{R} \$ 200,00)$, a adolescente tem a sua liberdade restringida, inclusive, para entrar em contato com a família, que permanece no interior do estado, além de ter o direito de estudar violado. A res- 
posta de que a patroa "não quer menina que estude por causa do bebê" significa, na verdade, que é esperado que a adolescente fique sempre disponível para cumprir sua função de babá, ainda que isso resulte em graves prejuízos a ela. A forma como a história da adolescente é narrada pelo jornal enfoca os desrespeitos e a privação de direitos relacionados ao TID. A adolescente figura como um objeto "cedido" pela tia e é posicionada pela matéria como "vítima", passiva frente às imposições restritivas da patroa.

Do entendimento do trabalho infantil como uma violação de direitos, ao longo da cobertura, esse tipo de trabalho infantil passa a ser conceituado como um crime, um crime disfarçado por "boas intenções", como uma forma de relação de poder sustentada por "verdades" culturalmente aceitas e práticas arraigadas. A visão tridimensional de poder sustentada Lukes (1980) nos auxilia a compreender melhor essa perspectiva porque a ideia que o jornal, naquele momento, está construindo acerca do TID é a de que ele seria sustentado por um poder latente que atuaria de maneira não explicita para as concernidas. Assim, a dominação referente ao TID ganha contornos nos media não apenas de uma relação de power over contra a qual as afetadas não podem lutar em razão das assimetrias de recursos e possibilidades, como também de uma força cuja atuação é latente, implícita e, assim, nem ao menos pode ser reconhecida como tal.

O Liberal publicou uma reportagem especial sobre a temática do TID em que o título era "Um crime maquiado rouba os direitos da infância". Logo no primeiro parágrafo se lia:

Lavar, passar, cozinhar, varrer a casa e cuidar de crianças. Se para adultos essas tarefas já são um grande esforço físico, para as crianças representam desgaste dobrado. O trabalho infantil doméstico (TID) é um crime que, maquiado pela oferta de "ajuda" a quem não tem oportunidades, contraditoriamente nega às vítimas o direito de brincar, estudar e escolher uma profissão. (O LIBERAL, 12/02/2004)

O termo "trabalho infantil doméstico" adquire, então, o status de um conceito no espaço de visibilidade midiática com apresentação de uma definição que denuncia a ambiguidade dessa prática: trata-se de um crime, porém maquiado pela justificativa de que seria uma forma de ajuda mútua. O discurso do jornal apresenta uma conotação afirmativa e consistente sobre a definição do TID, dis- 
tanciando-se, portanto, das incertezas presentes na cobertura dos primeiros dois anos. Nesse momento, a parceira entre Cedeca-Emaús e Grupo ORM, responsável pelo jornal $O$ Liberal, encontra-se consolidada, e o jornal apresenta-se como um agente engajado no processo de enfrentamento ao TID. As trabalhadoras domésticas são posicionadas como "vítimas" dessa forma subjacente e contraditória de poder, na qual se promete uma chance de autonomia para sujeitos que muitas vezes estão em situação de vulnerabilidade, mas o que ocorre são formas de tolhimento das ações dessas pessoas. A discussão que Honneth (2007, 2012a) faz sobre o reconhecimento ideológico possibilita essa percepção matizada sobre a tematização do TID. (MAIA; CAL, 2014) Isso porque, de forma recorrente, o discurso dos jornais ressalta o componente ideológico que alimenta o TID: à primeira vista, esse tipo de trabalho é considerado uma alternativa possível para que meninas pobres consigam melhores condições de vida. Essa perspectiva é crível porque, nutrida por raros exemplos de quem, por meio do TID, mudou de vida ou porque significa acesso a bens sociais e culturais que, de outra forma, aquela menina não teria. Entretanto, o que o jornal denuncia é que essas promessas não são cumpridas e, por isso, trata-se de um "crime maquiado".

A perspectiva do TID como ajuda mútua também foi discutida em outras matérias, juntamente com a posição das adolescentes envolvidas como "afilhadas” ou "agregadas" que, ao invés de remuneração, recebiam, em troca dos serviços domésticos, roupas, calçados e alimentação, conforme se constata abaixo:

Dona Raimunda Alcântara Lima, mãe de Paula Fernanda, de 17 anos, já amargou a experiência de ter uma filha no trabalho doméstico. Aos 16 anos, Dora, hoje adulta, mudou-se para Belém, para empregar-se na casa de conhecidos. 'Prometeram estudo e tudo que ela precisasse. Não prometeram salário. Como aqui [em Soure] não tem emprego, ela se empolgou, mas passou só três meses. Ela trabalhava como uma escrava, dava até banho em porco', relembra a senhora [...]

(O LIBERAL, 09/03/2003)

A sujeição das adolescentes à dominação no TID é referida por meio da analogia ao trabalho escravo. Poucas vezes, durante os 10 anos de matérias investigadas, as próprias afetadas utilizaram essa referência. Esse discurso estava presente, sobretudo, na fala de especialistas e de agentes sociais, além de aparecer 
expresso nos títulos, subtítulos e outros recursos de edição dos jornais. Segundo a mãe de uma ex-trabalhadora infantil doméstica, não era o fato de não receber salário que caracterizava o TID como escravidão, mas sim ela ter que realizar todo o tipo de serviço. Mesmo sem a promessa de salário, a menina seguiu para o TID em troca de benesses. De modo recorrente, as pessoas afetadas citam nas matérias que os patrões prometeram dar "tudo que a menina precisasse", no entanto, há um forte descompasso entre o que a menina e a sua família consideram o "necessário" e o que as famílias empregadoras pensam acerca disso.

Em uma entrevista de página inteira no jornal Diário do Pará, a advogada Celina Hamoy, coordenadora do Cedeca-Emaús, é questionada sobre violência e direitos da criança e do adolescente. Um dos focos da entrevista foi o TID. Ao ser indagada sobre se esse tipo de trabalho infantil podia ser considerado uma violência, ela responde:

É com certeza uma violência. [...] E a violação acontece principalmente pelo imaginário que existe na sociedade: 'Não, ela não está trabalhando, eu to ajudando, isso é tão comum'. Aí a menina começa a chamar a patroa de tia, de madrinha, começa a haver aquela troca: 'Tu me dá trabalho, eu te dou roupa'. Nada mais é e chega a caracterizar o trabalho escravo mesmo. (DIÁRIO DO PARÁ, 27/04/2008)

O TID, assim, é colocado como uma violação de direitos em razão de processos de dominação suavizados por meio da sua caracterização como ajuda, como uma "caridade" para com uma menina pobre. A violência do TID não é caracterizada por suas formas explícitas, mas reside no fato de existirem consensos sociais que fazem com que o ele seja aceito socialmente. Como afirma Perissinoto (2008), o poder (como power over) possui uma dimensão fundamentalmente coativa que não se encarna, porém, de modo preponderante por meio da violência física. O discurso do jornal e dos atores sociais chamados a se pronunciar nesse espaço de visibilidade ressalta, portanto, as desvantagens que a prática do TID pode acarretar para meninas envolvidas, ainda que aparentemente, ou melhor, socialmente, seja considerado como uma relação de ajuda mútua, na qual a ambiguidade entre ser ou não da família incentiva o não pagamento de salário. Por esses motivos, a representante do Cedeca-Emaús o caracteriza como trabalho escravo. Ela afirma que existe uma aceitação social dessa prática, o que 
dificulta a percepção do TID como um problema. A forte diferença entre o valor merecido pela atividade realizada pelas adolescentes e o que elas efetivamente recebem como pagamento também é criticada.

Os jornais apresentaram ainda histórias de vida que reforçam essa vitimização silenciosa, latente e ideológica realizada pelo TID. Vimos, no primeiro trecho apresentado nesta seção, que o discurso do jornal afirmava, em 2001, que, por se considerar parte da família, uma adolescente trabalhadora doméstica não teria os seus direitos violados como tantas outras. Em 2008, a retranca de uma matéria de página inteira sobre dados acerca do TID, publicada naquele mesmo jornal, aborda o assunto de forma bastante distinta (Figura 9).

\section{»Uma vida inteira de sacrifícios desde os 5 anos}

\begin{abstract}
Se as estatísticas são excelentes indicadores das injustiças sociais, as histórias e dramas humanos traduzem o que os números apontam. A história de Maria Aparecida dos Santos revela, na prática, o que é trabalhar na infância. Ela nasceu no município de Vigia, em 1964. Aos cinco anos veio para Belém morar com a madrinha. A promessa era educá-la e favorecer oportunidades de instrução e emprego. Nunca mais viu os pais analfabetos ou os irmãos. Passou a infância carregando compras, lavandochão,cozinhandoe passando
\end{abstract}

pela casa dos parentes da antiga patroa, sempre como doméstica. Um dos ex-patrões a trouxe para Brasilia, onde, pela primeira vez, teve carteira de trabalho assinada Tinha, entáo, 41 anos de idade. $\mathrm{Na}$ capital federal conseguiu tirar os documentos, trocou de empregoe hoje trabalha como diarista. Tudo nela revela a vida de sacrifícios: mãos calosas, aparência envelhe cida, ar cansado.

Noquartominúsculoemque vive sozinha, na cidade satélite de Brazlândia, ela tem uma única diversão: ver televisão. Durante a entrevista admite que tem medo da morte e da doença. "Vou morrer sozinha $e$ às vezes eu penso: quem é que vai me enterrar?"

Explico para Aparecida o que é trabalho infantil doméstico. Um longo silêncio se põe entre nós até que ela sorri e deixa escapar a mágoa que ocultou a vida inteira: “No meu tempo o governo não ligava se tiravam a gente de casa para servir de criança-escrava". Pergunto a ela o que faria se pudesse alterar o passado: "Ah, eu ia ser professora... ou enfermeira. Acho lindo", conta, sorrindo.

Figura 9 - Trecho da reportagem "Trabalho ainda ameaça infância", publicada no Diário do Pará, em 30 de março de 2008

Fonte: Diário do Pará.

O drama vivido pela personagem da matéria, Maria Aparecida, remonta à situação dos pais analfabetos que viviam no município de Vigia (PA) e à possibilidade de educação por meio da ida para a casa da madrinha na capital. Apesar disso, Maria Aparecida conta inicialmente com orgulho sua relação com a família empregadora: ter cuidado de todas as crianças, ser tratada como parte da família, fazer bolo ao gosto do "padrinho". O contraponto é feito pelo discurso do jornal, quase como uma ironia: “Talvez por ser da família não tinha folga semanal e muito menos férias”, expondo as ambiguidades inerentes à ideia de que a trabalhadora doméstica ou "cria” faz parte da família. Aparecida circulou entre diferentes núcleos familiares ligados a sua antiga patroa, como os casos relata- 
dos por Motta-Maués (2008). Nem a cidade de destino, segundo a abordagem do jornal, coube à Aparecida escolher: "Um dos patrões a trouxe para Brasília [...]”. Em cada um dos episódios contados sobre a vida de Aparecida, ela é posicionada como um sujeito sem autonomia ou possibilidade de decisões sobre a própria vida. Ganha relevo, assim, a evidência de uma relação de dominação que não é marcada apenas pela relação patroa/empregada, mas sim por uma espécie de condição geral de subalternidade na qual ela foi colocada praticamente do início ao fim da vida. Por um lado, confirma-se o caráter tácito dessa forma de dominação, mas, por outro, já não diz respeito a um único lar, mas a toda uma trajetória profissional marcada por essas relações, evidenciando também essa espécie de generalização da dominação e da condição de subalternidade, como se fosse algo intrínseco àquele sujeito. Isso fica ainda mais evidente quando, na meia idade, Aparecida se questiona sobre as próprias realizações e sobre quem irá enterrá-la.

Frente ao modo como Aparecida conta sua história, a repórter se sentiu na obrigação de interferir, para iluminar uma situação de extrema violação dos direitos. Quase como a quiromante que leu a sorte da doméstica na prosa de Maria Lúcia Medeiros, transcrita no primeiro capítulo deste livro, a repórter "explica" a Aparecida o que é o TID. Aquela mulher que tinha corporificadas marcas da realização de serviços domésticos desde os cinco anos precisava, então, de um agente externo - que não eram as organizações sociais que enfrentavam a problemática, era a própria jornalista que fazia a reportagem - para saber o que tinha ocorrido consigo, saber o que era "trabalho infantil doméstico", como termo político cunhado por especialistas e organizações de direitos humanos.

A relação mesma que a repórter constitui com a entrevistada se configura como power over, na medida em que marca a subalternidade dessa última, uma posição que precisa de tutela, de intervenção para enxergar com "clareza" as situações às quais têm se sujeitado. Motta (2007 argumenta que o jornalista é essencialmente um narrador discreto, que "utiliza recursos de linguagem que procuram camuflar seu papel como narrador, apagar a mediação. [...] Finge que não narra, apaga sua presença”. (MOTA, 2007, p. 155) Entretanto, nesse caso, a presença da repórter adquire destaque na narrativa jornalística ao "trazer à luz" a consciência daquela ex-trabalhadora infantil doméstica. Portanto, além da vitimização atribuída à história da personagem, ainda há no texto a presença da jornalista, reforçando esse lugar inferiorizado. A partir dessa interferência da 
jornalista, Aparecida consegue, segundo o discurso do jornal, expressar "a mágoa que ocultou a vida inteira": a de que, no final das contas, havia sido uma "criança-escrava".

Embora, no início da matéria, Aparecida tenha sido representada como vítima passiva e até orgulhosa do contexto de dominação no qual viva - por exemplo, pelo fato de o patrão só comer bolo quando ela fazia, ou por se sentir membro daquela família -, ao final do texto jornalístico, há um deslocamento dessa condição para a de vítima com capacidade de questionamento e de crítica. Após a revelação feita pela jornalista sobre em que consistia o "trabalho infantil doméstico", houve um descortinamento daquele contexto de dominação, antes latente, no qual Aparecida estava inserida. Nesse sentido, com base na concepção de poder de Lukes (1980, 2005), podemos entender aquela relação de poder na qual Aparecida estava inserida como majoritariamente baseada em power over, a partir da qual suas ações e seu modo de entender a situação, são afetados de modo significativo e de forma subjacente. Quando Aparecida tem a sua história recontada à luz dos enquadramentos da jornalista, embasada nos agentes de advocacy sobre o TID, há uma mudança no quadro interpretativo das situações que viveu. Portanto, aquele quadro implícito, subjacente de dominação é desvelado e, com isso, a personagem pode criticá-lo. O componente político da última fala de Aparecida reportada pelo jornal é evidenciado quando ela aborda o problema, não de um ponto de vista individual (a partir do que viveu apenas), mas coletivo. Ela responsabiliza os governos e denuncia a violência e o processo de dominação no TID, que seria uma forma de escravizar crianças.

Em geral, observamos que na tematização dos media sobre a definição do TID, as então atuais e antigas trabalhadoras domésticas foram posicionadas recorrentemente como "vítimas", ou seja, como sujeitos que sofrem maus-tratos, a privação de direitos como do direito à convivência familiar e comunitária, que têm suas possibilidades de escolha reprimidas e, finalmente, como escravas. Os principais sentidos mobilizados em torno do que era desse trabalho infantil foram: TID como uma violação de direitos, como escravidão, como um crime maquiado que rouba a infância. Sentidos esses que buscavam questionar entendimentos largamente aceitos na sociedade, como o de que o TID é um bom destino para meninas pobres, principalmente, do interior do Estado.

Entretanto, houve, ainda, espaço na cobertura dos jornais sobre a definição do TID, no qual se percebe o posicionamento de meninas trabalhadoras domés- 
ticas como "resistentes" ou, ainda, em frequência bem reduzida, como "sujeitos políticos". Mesmo assim, a grande maioria das matérias que faziam essas abordagens distintas acerca do posicionamento das afetadas apresentava concomitantemente o posicionamento como "vítimas". Talvez porque, parafraseando Hauggard (2012), o poder como emancipação seja "parasitário" ao poder como dominação, o que também equivale a dizer, na perspectiva foucaultiana, que relações de poder como power over podem se apresentar como espaço aberto para resistências.

Somente uma matéria apresentou o posicionamento dos sujeitos afetados como "resistentes"isoladamente, evidenciando, assim, uma percepção de poder como power to. Trata-se de uma notícia publicada no Diário do Pará sobre uma certificação que a OIT e o Movimento República de Emaús concederam ao Banco da Amazônia (Basa) em reconhecimento à contribuição do banco na inserção de adolescentes ex-trabalhadoras infantis domésticas no programa primeiro emprego. Na matéria, uma adolescente atendida pelo Petid é ouvida:

São 85 os jovens que participam atualmente do programa Adolescente Aprendiz do Banco da Amazônia. Uma delas, a adolescente Thayslane, conta como foi a experiência: 'Saí de um emprego pesado, que, na maioria das vezes não me dava oportunidade para estudar. Agora, entrei em um aprendizado profissional, que me prepara para um futuro promissor, visto que estou recebendo orientações de profissionais competentes, que me transmitem experiência e conhecimento e oportunidade para seguir meus estudos'. (DIÁRIO DO PARÁ, 24/04/2004)

Nesse caso, a menina ouvida não detalha a situação anterior de trabalho, porém ressalta que está, por meio do estágio no banco, perseguindo um futuro mais promissor. Assim, é possível perceber que lhe é atribuído um lugar distinto em relação aos das personagens das matérias anteriormente citadas. O que está em destaque é a capacidade dela de buscar novos caminhos por meio de outro tipo de inserção profissional que não seja o trabalho doméstico, considerado um "emprego pesado", que restringe oportunidades de estudo. Dessa forma, a ideia de resistência não estava restrita a formas de atuação cotidianas de enfrentamento do poder como dominação, conforme discutido por Scott (2011). Segundo 
o discurso desenvolvido pelo jornal, "resistente" era a menina que conseguia superar a condição de trabalhadora infantil doméstica e buscar outros modos de vida, ainda que isso venha como consequência da participação desse sujeito em uma ação organizada por uma instituição.

Esse movimento de transformação nunca era apresentado como uma ação própria. ${ }^{7}$ Quando as adolescentes eram posicionadas como "resistentes" ou ainda "sujeitos políticos", havia um padrão narrativo recorrente: expor primeiramente os dramas vividos pela personagem para, em seguida, atestar a mudança de vida em razão da inserção da adolescente no Petid ou em outro programa de enfrentamento a essa problemática:

R. S. L. M., 13 anos, moradora do Benguí e cursando a $6^{\text {a }}$ série do ensino fundamental, é um exemplo dessa triste realidade. A menina conta que com sete anos de idade trabalhava com vendas em um condomínio fechado. Aos 9 passou a ser babá, atividade pela qual às vezes não recebia dinheiro, mas roupa como pagamento. Ela revela que após entrar no programa do Cedeca-Emaús acalenta o sonho de ser médica. 'Aprendi que o trabalho é para adulto e não para criança', diz. (DIÁRIO DO PARÁ, 22/07/2003)

Após participar do Petid, a adolescente relata que modificou sua percepção sobre o que é o TID e ressalta que é uma atividade apenas para adultos. Essa ideia de que a percepção sobre os malefícios do TID só foi provocada pela inserção desses sujeitos em programas de enfrentamento é abordada, de modo recorrente, pelos jornais quando há o posicionamento das afetadas como "resistentes" ou “sujeitos políticos".

Em outra matéria, ao mesmo tempo em que é apresentada a fala da então ministra Benedita da Silva sobre as oportunidades que perdeu por ter sido trabalhadora infantil doméstica, ${ }^{8}$ há o relato de uma criança que, após ser atendida por um programa de combate ao TID, teve sua vida alterada e passou a perceber a situação vivida anteriormente como prejudicial.

7 A adolescente Thayslane, da matéria anterior, por exemplo, era uma das meninas atendidas pelo Petid.

8 Avaliamos que a fala da ministra, ressaltando os prejuízos do trabalho infantil para sua trajetória de vida, cria, de certo modo, um paradoxo não discutido na reportagem em relação ao fato de que, a despeito do TID, Benedita havia se tornado ministra da República. 
Elizabeth Cristina Santana, hoje com 11 anos, por dois anos enfrentou uma rotina semelhante a de um adulto. Acordava cedo, ia para escola, onde ficava até às $11 \mathrm{~h} 30$. Ao sair, tinha meia hora para tirar o uniforme, almoçar e ir para o emprego: uma casa de família. Por R \$ 10 mensais, ela cuidava de uma criança mais nova do que ela. 'Eu pedi para minha mãe, queria ajudar com dinheiro em casa', disse. Ela conta que, durante o período em que trabalhava não sentia cansaço ou não julgava que a atividade atrapalhasse os estudos. Hoje, essa ideia mudou. Há um ano, a menina, moradora de Belo Horizonte, passou a freqüentar uma escola de circo. 'Hoje aprendo trapézio. É uma vida muito melhor e minha mãe ficou muito feliz'. O rendimento escolar, completa, também hoje é superior. (DIÁRIO DO PARÁ, 10/09/2003, grifo nosso)

Em um primeiro momento, apresenta-se a resignação da adolescente em relação ao TID, pois não sentia cansaço e nem achava que poderia atrapalhar os estudos. Contudo, após sua inserção na organização não governamental Circo de Todo Mundo, ela passou a questionar a prática que realizava até então. Entre outros papéis atribuídos às organizações sociais que enfrentavam o TID na cobertura midiática, estava o de entidades "esclarecedoras", como quem traz à luz sujeitos que viviam uma realidade "sombria” enquanto trabalhavam como domésticas.

Embora crianças e adolescentes afetadas tenham voz no noticiário acerca da conceituação do TID, o que, em tese, demonstraria a possibilidade de "autoexpressão dos dominados” (MIGUEL, 2011) na medida em que não são somente especialistas e representantes de organizações sociais que estavam falando por elas nos media, o modo pelo qual esse lugar de fala é construído, ainda que para demonstrar um processo de mudança da condição opressiva, reforça a necessidade de tutela desses sujeitos, já que só lhes é permitido esse discurso de superação quando participam de projetos ou programas sociais que lhes dêem suporte. Ou seja, as conquistas relativas ao reconhecimento da própria condição e ao empoderamento desses sujeitos para que busquem outra realidade estão atreladas, no entanto, a uma dependência em relação a essas organizações de enfrentamento ao TID.

Esse caso traz um problema à discussão sobre o "falar em nome de outros". (ALCOFF, 1991; MAIA, R., 2012; URBINATI; WARREN, 2008) Segundo Alcoff 
(1991, p. 9), ao falar pelos outros ou falar sobre os outros, estamos representando "as necessidades, os objetivos, a situação dos outros e, na verdade, quem eles são", o que, segundo a autora, atua na construção do lugar que esses outros, por quem se fala, ocupam no mundo. Portanto, falar por outro implica participar da construção de lugares e papéis sociais que são atribuídos a esse outro.

Os discursos contrários ao TID e sobre o que seriam os melhores interesses das crianças e adolescentes envolvidos no TID foram majoritariamente apresentados e sustentados nos media investigados por atores sociais e especialistas (o que correspondeu a 50\% das fontes ouvidas, como apresentamos na p. 137). Os agentes de advocacy atuaram como representantes autoautorizados das afetadas pelo TID. De acordo com Urbinati e Warren (2008), nesse tipo de representação, não há necessidade da autorização prévia dos concernidos. ${ }^{9}$ Organizações e atores sociais atuam "em nome de interesses e valores que acreditam que devem ter um impacto”. (URBINATI; WARREN, 2008, p. 403) Assim, o interesse em questão é a erradicação do TID, e, em prol dessa causa, agentes de advocacy atuam representando as meninas envolvidas nessa prática, buscando não apenas influenciar políticas governamentais, mas, principalmente, a cultura e os discursos em torno desse trabalho infantil.

Nesse cenário, trabalhadoras (e ex-trabalhadoras) infantis domésticas também tiveram voz na cena midiática, ainda com um número bem menor de ocorrências, porém o lugar de fala atribuído a elas era fincado, sobretudo, no relato de situações opressivas e a desrespeitos vividos no exercício do TID. Assim, apesar de terem espaço de fala, o modo como os jornais construíram esse lugar, ao invés de proporcionar um discurso "libertador" - nos moldes mencionados por Alcoff (1991) e Spivak (2010) -, capaz de romper com a posição subalterna ou de opressão, acabou por reforçar, em alguma medida, esse lugar subalterno, porque as falas críticas ao TID ou mesmo de superação eram permitidas, essencialmente, a quem participava de programas sociais (Petid sobretudo). Portanto, as vozes de destaque no enfrentamento ao TID na arena midiática foram daqueles que

9 Os autores argumentam que a representação autoautorizada tem crescido muito nos últimos anos. Trata-se de um fenômeno multifacetado em que o objeto/sujeito representado pode variar entre temas (direitos humanos, educação, meio-ambiente), grupos (como mulheres, crianças, marginalizados etc.) ou mesmos discursos, ao defender determinadas posições ou argumentos. Portanto, esse tipo de representação implica desafios em relação aos modos de autorização e aos processos de accountability que deveriam sustentá-lo. (URBINATI, 2008) 
falavam em nome das meninas e mulheres envolvidas. Para Alcoff (1991), há casos em que o ato de falar por outros pode ser a melhor forma de combater determinadas situações. De fato, quem iniciou o questionamento público da prática do TID foram organizações internacionais (OIT; Unicef) e locais (Cedeca-Emaús e parceiros). Entretanto, a medida para avaliar esse processo de falar em nome de outros é a resposta à pergunta: "vai permitir o empoderamento das pessoas oprimidas?”. (ALCOFF, 1991, p. 29, tradução nossa)

Lançando essa pergunta ao contexto midiático: quais as repercussões para a configuração política do TID desse gesto de representação autoautorizada por parte das organizações sociais e do enquadramento das falas políticas das afetadas como possíveis somente a partir da chancela desses agentes?

Outra matéria contribui para iluminar essa questão:

A menina, que não teve tempo para brincar por conta do trabalho de babá, hoje está com a auto-estima resgatada e sonha em fazer Administração. 'A vida mudou bastante. Do jeito que era... Está muito melhor agora', comemora Thayslane, de 16 anos. Thays está estagiando na Agência do Basa [...]. Thays não abandonou os estudos no turno da manhã, numa escola pública, e hoje cursa o terceiro ano do Ensino Médio. Gostava da patroa, mas admite que não tinha o preparo necessário para cuidar de um bebê. 'Quando o bebê se engasgava a mamãe dizia para soprar no rosto dele. Quando ele não estava bem, eu levava para minha avó, lá em casa'.

Thays faz parte de uma triste estatística de crianças que partem para o serviço doméstico, sob o incentivo da família, para complementar a renda da casa. [...]. Por isso, a irmã de Thays, Thayana da Silva Lima, também arrumou o subemprego de babá na vizinhança. 'O dinheiro que a gente ganhava era para pagar apostila na escola e comprar comida para casa', lembra Thays.

A vida delas mudou quando conheceram o Centro de Defesa da Criança e do Adolescente (Cedeca) [...]. A família conseguiu uma bolsa -escola, Thays fez um curso de computação na República de Emaús e conseguiu um estágio de 18 meses, iniciado em dezembro do ano passado. Hoje, a casa da família, que era de madeira e estava bastante deteriorada, está sendo substituída por uma de alvenaria. (O Liberal, 18/03/2004, grifo nosso) 
Pelo modo como percebemos as relações de power to e o posicionamento de sujeitos como "resistente" na cobertura dos media, desenha-se um processo exógeno, isto é, não são os sujeitos que transformam a si mesmos. Eles só podem começar a fazê-lo a partir de estímulos de organizações sociais e outros agentes. De maneira complementar, os discursos acerca da resistência no TID se referem a alternativas para além dele, e não de modificações no modo mesmo como ele é realizado. De tal forma que a dominação nesse tipo de trabalho infantil seria tão forte que só haveria possibilidade de resistência ou emancipação fora dele, o que, a nosso ver, está em congruência com o discurso do Petid, segundo o qual o TID é incompatível com a infância e com a garantia dos direitos da criança e do adolescente, como discutido no segundo capítulo.

Sobre as relações de poder como power with em torno da definição do que era esse tipo de trabalho infantil, encontramos três referências nas matérias estudadas, em que meninas antes atendidas pelo Petid passaram a fazer parte das ações de enfrentamento a esse problema, que apresentaremos adiante. Em uma única reportagem, houve a tematização acerca dos papéis que os adolescentes devem desempenhar nessa luta, e a fonte foi a coordenadora técnica do Petid:

\footnotetext{
'Este trabalho de reconhecimento da situação dessas crianças e adolescentes que estão no mercado de trabalho é o primeiro passo para se combater o trabalho infantil. Mas precisamos também dar condições para que eles possam ser protagonistas da sua própria história', afirmou Fátima Santos, coordenadora do Programa de Enfrentamento ao (Petid) do Cedeca-Emaús. (O LIBERAL, 01/10/2009)
}

Apesar de o protagonismo juvenil ter sido uma preocupação do Petid, expressa nos documentos e relatórios do Programa, como vimos no segundo capítulo, o modo como os jornais abordaram essa temática não problematizou esse aspecto, tratado de forma isolada e extremamente pontual.

Em 2007, o lançamento de uma nova campanha de publicidade do Petid, estimulou a produção de matérias jornalísticas acerca desse assunto. As personagens ex-trabalhadoras infantis domésticas eram meninas atendidas pelo Petid nos primeiros anos do Programa e que, naquele momento, encontravamse maiores de idade e fazendo faculdade: 
A estudante de jornalismo Aline Abrahão, de 21 anos, foi atendida pelo Petid onde fez várias oficinas durante cerca de quatro anos até conseguir mudar o rumo da sua vida. Sobre a experiência que teve com o trabalho infantil doméstico, ela prefere nem falar. Hoje, ela atua como voluntária no projeto, ajudando na realização de oficinas para outras meninas. E toca a sua vida com os olhos voltados apenas para o futuro.

A estudante de Direito Thaís Fagundes, de 20 anos, conta que teve uma curta passagem pelo mundo do trabalho doméstico. [...] A partir daí, ela decidiu procurar a entidade. Fez oficinas de Informática, Rádio Comunitária e Fanzine e, hoje, assim como Aline, ajuda na realização de oficinas para outras meninas, vítimas do trabalho infantil doméstico. (O LIBERAL, 13/06/2007)

Como colaboravam com o Petid, essas meninas foram indicadas para dar entrevistas quando os meios de comunicação solicitavam histórias de vida para as matérias. Ainda que no texto fossem posicionadas preponderantemente como sujeitos políticos, atuantes no enfrentamento ao TID, o fato de figurarem como ex-trabalhadoras infantis domésticas nos media causou constrangimentos e prejuízos ao convívio social dessas meninas, principalmente no ambiente universitário, conforme relataram em entrevista à pesquisadora no dia 13 de junho de 2013.

Chama a atenção, o tratamento da história de vida de uma adolescente de 16 anos, naquela época, bolsista do Cedeca. No exemplo a seguir, os dramas vividos pela personagem desde os sete anos são abordados de modo mais detalhado. Contudo, a maneira pela qual ela apresenta sua própria história é colocada como uma forma de luta contra o TID, já que, a partir do relato das suas vivências, ela pode ajudar a convencer sobre os problemas relacionados ao TID:

Anayara Nunes, 16, que hoje é bolsista no Cedeca-Emaús, já sentiu na pele o drama do trabalho infantil. Com apenas sete anos, a menina conta que trabalha como babá de crianças pouco mais novas que ela. $[\ldots]$

Com o Cedeca-Emaús, a menina participa de grupos de arte do centro e desenvolve atividades próprias da sua idade. 'Minha vida mudou para muito melhor depois que entrei no Cedeca. Hoje, estou ajudan- 
do o grupo a convencer pessoas sobre a importância de se combater o

trabalho infantil', informou Anayara. (O LIBERAL, 17/11/2008)

De forma geral, por meio da análise dos lugares atribuídos às afetadas pelo TID e das significações culturais mobilizadas na cobertura do que era o TID, avaliamos que, na perspectiva dos media acerca dessa primeira temática, a prática política de trabalhadoras e ex-trabalhadoras infantis domésticas foi bastante reduzida. Elas figuraram, sobretudo, como pessoas que sofreram com essa prática e que tinham casos de exploração e violência para relatar.

Mesmo quando as matérias as posicionavam como "resistentes" ou como "sujeitos políticos", anteriormente essas meninas e mulheres eram chamadas a se pronunciar como vítimas de relações de power over que constrangiam as escolhas possíveis, ou ainda que atuavam de modo silencioso e subjacente. É pertinente dizer que, para figurarem como "resistentes", era necessário explicar ao que resistem e, portanto, falar sobre o TID. A questão, na verdade, é o acento dado e a preponderância de uma condição ou posição ("vítima", "resistente", "sujeito político") em relação à outra. Isso porque não se tratam de categorias rigorosamente distintas. Esses posicionamentos estão, de certo modo, em interseção. Contudo, na cobertura sobre as definições do TID, foi atribuído um destaque significativo ao papel de vítima.

Ainda a respeito das relações de power over, o tratamento do TID como dominação induz ao questionamento: quem domina quem? De modo mais genérico, os textos dos jornais, por um lado, se referiam à cultura brasileira como opressora e, de forma mais específica, aos patrões por meio do relato de castigos, humilhações e violências que infligiam a meninas trabalhadoras domésticas.

Um tema específico que tornou mais borrados os contornos dessas relações de dominação no TID e que contribui para desvendar a complexidade inerente à definição do conceito de TID é o das distinções entre o serviço realizado na casa de terceiros e o realizado na própria casa da criança ou do adolescente. Do total de temáticas encontradas nas matérias jornalísticas, essa discussão apareceu em 5,3\%, e apenas em O Liberal. Essa foi uma temática abordada de modo tangencial em matérias que propunham uma discussão sobre trabalho infantil e sobre o trabalho doméstico de modo mais geral e em matérias factuais a partir de ocorrências em lares de família. 
Apesar de pouco tematizada no espaço de visibilidade dos media, a relação entre o trabalho doméstico realizado por meninas nas casas de suas próprias famílias e o trabalho realizado na casa de terceiros é uma temática essencial para discussão da politização do TID. Isso porque, como apresentamos no primeiro capítulo, ainda que a menina execute serviços domésticos para os próprios pais, isso pode ser considerado "trabalho infantil", quando cabe à criança ou adolescente a total responsabilidade sobre as tarefas da casa ou o cuidado com os irmãos. Vimos também que havia uma dificuldade para os agentes de advocacy trabalharem publicamente o discurso do TID como um problema na própria casa da família. Se o TID na casa de terceiros já era difícil de ser questionado em razão da larga aceitação social e cultural, o trabalho para a própria família apresentava uma dificuldade muito maior por ser considerado frequentemente como uma obrigação "natural”, sobretudo das filhas mais velhas. Daí decorre, a nosso ver, o motivo pelo qual essa temática apareceu tão pouco na cobertura jornalística.

Houve duas formas principais pelas quais esse tema ganhou espaço no noticiário: como assunto secundário em matérias que tratavam de outros temas, como a situação da comunidade de Santana do Aurá, vizinha ao aterro com mesmo nome, ou ainda quando um cão morde uma criança que estava sozinha em casa sob os cuidados da irmã, ou ainda por meio de agentes sociais relacionados ao Petid, mas também sempre de forma tangencial. Raras vezes, o jornal discutia diretamente o trabalho para a própria família.

Na edição de $O$ Liberal de 8 de dezembro de 2002, uma reportagem de página inteira destacou as precárias condições de vida das famílias que vivem no entorno do Aterro Sanitário do Aurá. Uma das sub-retrancas, cujo título é "Comunidade é isolada pela pobreza", retrata a casa da menina Linda Inês, que cuidava dos irmãos menores para que os pais pudessem trabalhar na catação do lixo. Uma foto da menina com dois irmãos menores no colo acompanhava a matéria, denunciando que Linda Inês era tão criança quanto os meninos de quem cuidava. O discurso do jornal posiciona a menina como vítima daquela situação que não era apenas responsabilidade dos pais, mas da falta de condições estruturais e de políticas adequadas naquela comunidade.

Os dois bebês, sempre sem roupa e com a pele recoberta de sujeira do barro onde brincam, ficam sob os cuidados de Linda Inês, de 8 anos, a única menina dos 9 filhos, que é a 'mulher da casa'. [...] Mesmo com 
toda a esperteza, Linda Inês ainda não tem idade para dar conta de tamanha responsabilidade transferida para ela enquanto os pais correm atrás do sustento no lixão. [...] Apesar das condições de vida nada favoráveis, as crianças brincam unidas no quintal. Sem se preocupar com a origem dos brinquedos, elas correm com tranqüilidade em volta do poço que abastece a residência [...] (O LIBERAL, 08/12/2002)

Cabem a Linda Inês, os cuidados com a casa e com os irmãos. Por ser menina, essa responsabilidade foi designada a ela, apresentada pelo texto como "a mulher da casa". Além de colocar em evidência os problemas do TID na própria casa ("Linda Inês não tem idade para dar conta de tamanha responsabilidade”) de modo indireto, há referência a um nível estrutural de dominação que é relacionado às divisões de tarefas em casa como uma questão de gênero, como se coubesse apenas às mulheres e, por consequência, às meninas, a responsabilidade pelos serviços domésticos em suas casas. Mesmo tendo irmãos mais velhos, cabia a Linda Inês, "a única menina dos 9 filhos”, o serviço doméstico, aspecto esse abordado com naturalidade pelo discurso do jornal, já que não é problematizado. Na verdade, essa "obrigação" foi reforçada no texto pelo uso da expressão "mulher da casa". Esse modo de se referir à mulher (e à criança, no caso) atribui estritamente ao gênero feminino as responsabilidades pelo cuidado com aspectos relacionados à manutenção da casa. (OKIN, 2008) É como se a sua existência estivesse confinada àquele âmbito e como se essa relação "obrigatória” entre ser menina e cuidar da casa e dos irmãos fosse legítima.

Embora haja referência na matéria a situações de dominação, o texto termina com a ideia da redenção por meio da infância. A condição de criança é considerada propícia à busca por saídas imaginativas, ainda que em situações extremamente adversas, como a da família apresentada, porque as crianças inventam brincadeiras e criam oportunidades para viver esse período da vida e amenizar o sofrimento e a precariedade.

De modo subjacente, essa temática é tratada também em outra matéria. O assunto principal é o ataque de um cão da família a uma das crianças da casa:

Um cão atacou uma criança de oito anos que, acompanhada de outras sete irmãs, foi deixada sozinha em casa pelos pais, aos cuidados 
da primogênita, de 14 anos. Ferida no pescoço, a menina foi levada em estado grave para receber atendimento médico [...].

Vizinhos queriam levar as crianças para outro lugar, para dar-lhes banho e comida. Mas, temendo a reação dos pais, a mais velha, de 14 anos, não aceitou sair de casa. (O LIBERAL, 22/03/2004)

A notícia se restringe a relatar o ocorrido e menciona que a irmã mais velha havia ficado responsável pelas crianças. De acordo com o jornal, vizinhos relataram que os pais deixavam o cão solto para impedir que as crianças saíssem de casa na ausência deles. A matéria repercutiu e, no dia seguinte, foi noticiado o desdobramento dela com cobranças para que o Ministério Público e o Conselho Tutelar se posicionassem.

O processo de dominação patriarcal, em que a obediência ocorre por estar enraizada na cultura e nos costumes da sociedade (WEBER, 1991b), restringe as possibilidades de atuação da adolescente. Ela, por exemplo, recusa a assistência oferecida por temer desobedecer a ordem dos pais, ainda que fosse pelo próprio bem de si e das irmãs. No discurso do jornal, as crianças aparecem como vítimas de possíveis ataques, como o que acabou ocorrendo, e dos próprios pais, que as deixam sozinhas e criam ameaças para que as meninas tenham medo de sair de casa. Apesar de não discutirem com maior detalhamento a situação do trabalho infantil na própria casa, essas duas matérias ressaltam a vulnerabilidade das crianças quando são deixadas aos cuidados exclusivamente de uma irmã criança ou adolescente.

A temática do trabalho em casa ganha uma abordagem mais detalhada em uma matéria sobre os dados da Pesquisa Nacional por Amostra de Domicílios (PNAD) referentes ao período compreendido entre 2001 a 2005, acerca da realização de afazeres domésticos, que ressalta o fato de as mulheres trabalharem mais do que os homens em razão dos cuidados com a casa e com os filhos. Sobre o TID, a matéria diz que:

O levantamento revelou também, um dado que, na prática, muita gente já sabia. As meninas, desde cedo, são orientadas para o trabalho doméstico. Principalmente no norte do país, em que mais de 4,2 milhões de meninas entre 10 e 17 anos ajudam em casa. (O LIBERAL, $18 / 08 / 2007)$ 
Não há uma distinção no texto acerca do que é trabalho doméstico e o que é tarefa doméstica, de tal forma que, no momento da apresentação dos dados, o discurso do jornal faz uma crítica ao fato de milhares de meninas realizarem afazeres domésticos nos estados da região Norte e, no momento seguinte, quando é trazida uma personagem ao texto, ela reforça o valor positivo desse tipo de atividade para crianças e adolescentes.

A agente comunitária Cristina Mata, 33 anos, sabe bem o que é isso [afazeres domésticos por meninas]. Desde cedo, aprendeu em casa que deveria ajudar a mãe nos afazeres domésticos e a ser versátil. Hoje, casada com pedreiro, e com três filhas, entre 7 e 14 anos, ela se vira para administrar o trabalho, a casa, os filhos, o marido e o orçamento doméstico. [...] Sem empregada ou babá, a única ajuda que a agente comunitária recebe em casa é das filhas mais velhas, que desde pequenas, já estão aprendendo a se virar sozinhas. 'Eu ensino elas a lavar louça, varrer uma casa, até cozinhar algumas coisinhas. Só assim vou conseguindo dar conta de tudo', desabafou. (O LIBERAL, $18 / 08 / 2007)$

O trabalho das filhas em casa é considerado não apenas positivo como essencial para que a agente comunitária consiga "dar conta de tudo". De modo geral, os serviços domésticos realizados pelas filhas são vistos de forma positiva porque estimulariam o crescimento pessoal por meio de um aprendizado valorizado na vida adulta: "se virar sozinhas". Além disso, o fato de estar contribuindo com o bom funcionamento da casa e ajudando as mães é algo digno de valor para as próprias trabalhadoras infantis domésticas, como veremos na próxima seção nas discussões dos grupos focais. Há um descompasso, então, à crítica feita na primeira parte da matéria sobre os resultados da PNAD acerca da realização dos afazeres domésticos por crianças e o modo como, a partir da história da personagem, o componente educativo e de contribuição desses mesmos afazeres são ressaltados.

De modo geral, a partir das matérias analisadas, identificamos que os jornais tiveram bastante dificuldade para realizar distinções entre o TID e a realização de tarefas domésticas por crianças e/ou adolescentes em suas próprias casas. o Diário do Pará nem chegou a destacar esse assunto e, em O Liberal, o discur- 
so é construído de maneira ambígua, sem esclarecer as particularidades que podem distinguir uma prática da outra. Quando houve tentativas de fazer essas distinções no texto jornalístico, as vozes ouvidas foram de especialistas. $\mathrm{Na}$ verdade, de uma única especialista utilizada como fonte em distintas matérias acerca do TID.

Com objetivo de estimular um olhar social mais crítico às tarefas domésticas, durante o lançamento de resultados da pesquisa que o Cedeca e a UFPA realizaram em Belém sobre crianças que estudam e trabalham, a pesquisadora Maira Luiza Lamarão, uma das responsáveis pelo estudo, alertou que o que pode parecer apenas uma ajuda em casa, muitas vezes se trata de trabalho infantil, porque as crianças, ao invés de auxiliarem e contribuírem com o trabalho de um adulto, são colocadas como únicas responsáveis por tarefas não compatíveis com seu estágio de desenvolvimento.

[...] As atividades são variadas. Algumas delas são tarefas domésticas, trabalho braçal em estância e em oficina mecânica, malabarismo na rua e manicure.

A coordenadora da pesquisa, Mariluz [sic] Lamarão, adverte que todas podem ser caracterizadas como trabalho infantil mesmo que pareçam tarefas do lar. É o caso, por exemplo, de menina que toma conta da casa e dos irmãos enquanto a mãe trabalha. Ou do menino que faz serviços complementares ao da mãe na casa da patroa. (O LIBERAL, 12/09/2008)

Recorrendo à especialista, o jornal apresenta uma definição ainda bastante confusa do TID, equivalendo-o às tarefas domésticas num primeiro momento, porém indicando, num segundo, exemplos ligados ao TID de fato.

Em outra matéria, o jornal utiliza a mesma fonte para esclarecer as distinções entre essas duas práticas. Na notícia sobre dados da PNAD de 2008, intitulada "Trabalho infantil caiu apenas 0,7\%", a diferença é tratada de modo mais específico:

"A criança não pode se envolver no produto, mas no processo de trabalho. A criança pode, vez ou outra, aprender a lavar uma louça, por exemplo, mas como uma tarefa, não como algo que ela seja obrigada a fazer todos os dias”, explica Luiza Lamarão. (O LIBERAL, 01/10/2009) 
Assim, o trabalho em casa que explora, que se configura como TID, seria aquele em que a criança ou o adolescente é colocado como único responsável por certos serviços, ao invés de colaborar com o trabalho desenvolvido pelo adulto. Tarefa de casa, portanto, seria uma colaboração ao trabalho realizado por um adulto, enquanto que o TID em casa seria quando há uma obrigação e uma responsabilização exclusiva da criança ou do adolescente por determinada atividade doméstica.

O TID na casa da própria família é apontado nos textos estudados como um impulsionador para que a menina seja encaminhada a casas de terceiros. Foi o caso de uma adolescente personagem em uma das matérias analisadas:

Quando tinha oito anos, LSS saiu com a irmã menor de Bom Jardim, no Maranhão, onde morava com os avós, para morar com a mãe, o padrasto e outra irmã em Belém. Quando a mãe arrumou emprego, ela cuidava das irmãs. A mãe ficou sem trabalho novamente e LSS passou a cuidar do bebê da vizinha. Ganhava $\mathrm{R} \$ 5$ por semana. [...] LSS diz que não tinha tempo de brincar, nem para estudar e que agora tem novas oportunidades. 'Estou fazendo teatro na escola, curso de informática. Já fiz um monte de curso aqui no Cedeca, de políticas públicas, ética e cidadania, sexualidade [...]'. (O LIBERAL, $16 / 10 / 2003)$

A adolescente apenas cita que cuidava das irmãs para a mãe trabalhar e que, quando esta ficou desempregada, passou a cuidar do filho da vizinha. Por meio da análise da matéria, observamos o desvelamento da relação de power over como habilidade de constranger as escolhas disponíveis para o outro (ALLEN, 1998, 2000), cujo agente de dominação não é a patroa, mas a mãe da criança. O destino dela oscilava entre o trabalho em casa ou na vizinha de acordo com a situação da mãe. No texto, está presente aquela lógica narrativa que conforma o lugar de fala da menina trabalhadora doméstica como "vítima resistente", com condições de vislumbrar novas oportunidades a partir dos cursos que estava realizando no Cedeca-Emaús. Contudo, o foco da resistência não é ao TID em casa, sequer problematizado, mas o TID na casa de terceiros.

Na próxima seção, examinaremos como essas nuances e tensões na definição do TID foram discutidas nos grupos focais analisados. 


\section{Definições sobre Trabalho Infantil Doméstico nos grupos focais}

Pelo próprio modo como as interações se processam no interior dos grupos focais, os posicionamentos e as discussões, por mais que estimulados a partir de um roteiro pré-definido, não seguiram uma ordem linear ou monotemática. A dinâmica interativa desses momentos fez com que, por exemplo, ao abordar o que significava trabalho infantil, emergissem respostas acerca de outras temáticas, educação e violência. Entendemos que são fatores complexamente ligados ao TID, porém avaliamos como pertinente separá-los tematicamente para que fosse possível perceber matizes da configuração política desse tipo de trabalho infantil. Desse modo, decidimos pela identificação de preponderâncias para destacar as temáticas principais em cada momento interativo nos grupos analisados.

Após o destaque dessas macrotemáticas, o primeiro passo analítico foi identificar como as relações de poder eram evidenciadas nos grupos para, em seguida, analisar como meninas e mulheres afetadas pelo TID se posicionavam e eram posicionadas: se "vítimas", "resistentes" ou "sujeitos políticos". Além de examinar como esses lugares atribuídos diziam de significações culturais em torno do que é esse tipo de trabalho infantil.

Optamos por desenvolver a análise dos grupos focais a partir de subtópicos sobre as definições do TID levantadas pelas entrevistadas. Isso porque, pelo modo como se processam as discussões nesses grupos, havia, por vezes, a impossibilidade de separar a forma como se referiam a distintas relações de poder, já que num mesmo contexto de discussão as afetadas podiam mencionar e fazer transparecer tanto relações de power over, quando de power to e power with. De tal modo que a análise dessa primeira temática sobre o que é o TID foi dividida em quatro subtópicos: (a) Ser da família ou ser a empregada; (b) TID como prática escravizante; (c) Tensões entre ajudar, reparar menino e trabalhar; (d) Tensões entre o trabalho em casa e na casa da patroa. Nossa unidade analítica não se resumiu a falas isoladas, mas considerou preferencialmente contextos de discussão acerca de um mesmo assunto, os quais serão reproduzidos parcialmente. 
A ambiguidade entre ser ou não da família é apontada pelos estudiosos do TID (LAMARÃO, 2008; LAMARÃO; MENEZES; FERREIRA, 2000; MOTTAMAUÉS, 2008), conforme vimos no primeiro capítulo, e também pelos discursos dos media como um fator que alimenta relações de dominação e de power over. Na medida em que a menina é tida como se fosse da família, é como se não houvesse razão para o pagamento de salário ou ainda de folgas periódicas. Afinal de contas, ela estaria sempre no seio familiar.

Apesar de essa ideia ser sustentada por duas das ex-trabalhadoras infantis domésticas entrevistadas, em geral ela foi bastante questionada nos grupos focais. As próprias participantes procuravam fornecer argumentos e insumos para comprovar às demais o porquê de não "serem da família” na época em que exerciam o TID, como no caso dessa conversa no grupo "condomínio":

Moderadora: E na época em que vocês eram adolescentes? Vocês se sentiam parte da família?

Tamires: Eu me sentia parte da família e ela dizia 'você não é a minha empregada, você é a minha filha adotiva'. Também porque ela nem tinha filho, ela criava mais dois meninos que eram do caso do avô, do pai do marido dela. Ela dizia 'você é minha filha', tanto que ligavam pra ela, 'tá eu vou falar para a minha filha levar ai para você'. 'Mas que filha?', não sei o que... 'Uma que eu adotei'. [risos]

Wanderléia: Eu, nessa que eu trabalhei [...] que era prefeito de lá de Ourém [PA], eu me sentia da casa porque ele também era, bem dizer, parente dos meus pais. Então, eu me sentia da casa porque era assim, eles moravam aqui em Belém, só que morava lá [em Ourém] a cunhada dele e esse menino que eu tomava conta. Aí só iam para lá final de semana. Dia de domingo, eu ia para a casa da mamãe, lá para minha casa. [...] Aí, para onde eles [família do prefeito] iam, eu ia. Morava quase na beira do rio, que é um rio grande que tem em Ourém. Se eles iam para lá sentar em umas maloquinhas daquelas, eu tinha que ir. Eu ficava lá, do que eles comiam, eu comia, do que eles bebiam, eu bebia.

Tamires: Eu ia com a minha [patroa] até para Salinas [balneário paraense] que ela me levava, passava dois meses eu socada na praia com os meninos [...]. Ela era muito boa para mim.

Wanderléia: E daí é assim, não é? Até hoje graças a Deus eu não me senti acuada em casa de patrão. 
Karla: Mas também eu nunca me senti feito parte da família deles. Por mais que eu, que eles me levassem, eu comesse junto com eles na mesa, tudo. Mas eu nunca me senti fazendo parte da família, nunca. Porque sempre tem aquela diferença, tu vais sempre te colocar em teu lugar, nunca me senti parte da família, não.

Wanderléia: Esse que nem eu estou dizendo, que esse do prefeito, porque era da família, não é? Porque era parente, era o primo sei lá o que era... Só sei que era parente. Então querendo ou não...

Tamires: Mas essa minha ela sempre dizia: 'Nunca diga que você é minha empregada, diga que você é minha filha'.

Moderadora: Mas os outros filhos tinham as mesmas obrigações?

Tamires: Não, eles só estudavam.

Karla: Pois é! Por isso que eu estou te dizendo, que tu tinhas obrigações por mais que eles te tratassem bem e tudo, comesse junto com eles, mas tu tinhas aquela obrigação que filho não tem. Sempre tem uma diferença, não existe isso de dizer que a minha filha tem... Obrigação de cuidar da casa. Não tem aquela obrigação de levantar, de fazer...

Tamires: Não, eu não cuidava de nada não. Era só mesmo para servir de companhia, para brincar com eles. Eu era adolescente igual eles. Eles eram da minha idade, um de oito, um de nove. Era assim. Eu era da mesma idade deles. Era mais para estar ali brincando com eles. Agora do colégio, aí cada um ia para o seu colégio. Claro que eu estudava no do governo e eles no particular [risos].

Karla: Por aí já começou. Está vendo? Sempre tem, sempre tem essa diferença, não existe isso [de ser da família]. Sempre tem a diferença. (CONDOMÍNIO, grifo nosso)

Alguns elementos são apontados pelas participantes Tamires e Wanderléia como comprovações de que faziam parte da família. Tamires, por exemplo, justifica sua posição quanto ao pertencimento à família empregadora na adolescência, em razão de a patroa afirmar que ela era uma filha adotiva. Além disso, a patroa a levava para a praia, o que, para Tamires, era uma das demonstrações de cuidado e bondade: "Ela era muito boa para mim”. Quando a participante Karla questiona que, na verdade, havia uma diferença entre a menina e os filhos da família, já que a adolescente precisaria cuidar da casa, Tamires ameniza e diz que não cuidava "de nada”, "apenas” fazia companhia e brincava com as crianças. O posicionamento de Tamires acerca de sua condição na família empregadora nos remete a uma concepção internalizada de power over, porque não há um reconhe- 
cimento da relação de trabalho. E, em razão disso, não havia pagamento de salário. Nesse sentido, afirmar "fazer parte da família" ou ainda "eu não cuidava de nada não, era só mesmo para servir de companhia” são formas de justificar o TID.

Apesar de a patroa se referir à Tamires como "filha adotiva", os deveres vinculados a essa condição, inclusive a manifestação em dispositivos legais dessa “adoção", não são cumpridos, como, por exemplo, o direito de receber o mesmo tratamento que os outros filhos e de herança. Além disso, quando a adolescente sai dessa casa de família, é como se o laço de "filha adotiva" fosse rompido, na medida em que não há uma preocupação da família em relação à situação futura daquela menina. Portanto, embora Tamires considere o modo com a patroa se referia a ela um reconhecimento de sua condição como parte da família, sustentamos, a partir de Honneth (2007, 2012a), que se trata de um reconhecimento ideológico. Isso porque o "reconhecimento não pode consistir em simples palavras ou expressões simbólicas, mas deve ser acompanhado de ações que confirmam essas premissas”. (HONNETH, 2012a, p. 92, tradução nossa) Assim, a forma como o discurso da patroa é apresentado "Nunca diga que você é minha empregada, diga que você é minha filha”, revela forte componente ideológico que diz respeito ao apagamento de uma relação de dominação. Corrobora essa afirmação a implicação de um dever moral que essa lógica imputa à menina, que deve gratidão e obediência à patroa pela generosidade de lhe considerar uma "filha". (MOTTA-MAUÉS, 2008; FONSECA, 1995)

Para a entrevistada Wanderléia, a condição de ser parte da família advinha por um grau distante de parentesco com a família à qual servia e pelo fato de realizar os mesmos passeios e de fazer as refeições junto a eles. A oferta de comida é geralmente citada pelas ex-trabalhadoras infantis domésticas como um indicador do lugar que ocupavam na casa em que trabalhavam e da generosidade ou mesquinhez dos patrões. Nesse caso, ao afirmar que "do que eles comiam, eu comia, do que eles bebiam, eu bebia”, Wanderléia quer dizer que não havia diferença entre ela e os outros membros da família empregadora. O contraponto é feito pela participante Karla, que afirma haver sempre uma distinção entre a família propriamente e a agregada ou empregada. Uma diferença que marca o lugar em que a menina deve "se colocar" ao trabalhar em casa de família.

Haveria, portanto, um lugar que caberia à adolescente trabalhadora doméstica. Uma posição distinta daquela dos membros de fato da família. Essa posição marca a inferioridade da trabalhadora doméstica em relação aos outros com- 
ponentes daquele grupo familiar, ao mesmo tempo em que saber "se colocar" nesse lugar é apontado como uma virtude da doméstica, que evitaria a confusão entre papéis. De acordo com a perspectiva de Sousa (2009), uma posição dessa natureza seria sustentada por uma "hierarquia moral", internalizada e reproduzida de modo afetivo, como algo tácito, pelas meninas trabalhadoras domésticas. Entretanto, apesar de, nesse caso, não haver uma discussão sobre que lugar é esse no grupo focal, ele é apresentado para sustentar uma postura crítica em relação ao engodo de "fazer parte da família".

Ao longo da conversa, a própria participante Tamires, que se dizia parte da família, reconhece que havia uma diferença, não em relação às tarefas as quais era responsável na casa, mas sim em relação ao tipo de escola que cada um frequentava. À ex-menina trabalhadora doméstica, era natural que estudasse em escola pública, enquanto as crianças da família estudavam em escolas particulares. "Claro que eu estudava no do governo e eles no particular", afirmou. As outras participantes imediatamente riem e concordam com a afirmação, como se reconhecessem a naturalidade pela qual essa distinção é considerada, o que serve para Karla reforçar seu argumento de que a menina trabalhadora nunca é parte da família.

Assim, nesse mesmo trecho do grupo focal, há o posicionamento das afetadas pelo TID tanto como "vítimas" quanto como "resistentes", na medida em que as primeiras afirmações justificavam o TID por serem parte da família e as últimas demonstram um questionamento crítico e provocam uma fissura no quadro do reconhecimento ideológico em relação à promessa de tratamento como membro da família por meio do exemplo da educação. Há, assim, um tensionamento da ideia culturalmente defendida (MOTTA-MAUÉS, 2008) de que o trabalho doméstico de crianças ou adolescentes é justificado em razão de pertencerem à família empregadora.

No grupo das mulheres jovens, realizado na casa da patroa, as ex-trabalhadoras infantis domésticas apontam, ainda, outros elementos e argumentos que marcam a distinção entre ser ou não parte da família:

Moderadora: E vocês se sentiam parte da família quando trabalhavam?

Nanã: Nunca me senti. Eu sempre diferenciei porque a pessoa trata a gente bem, mas na verdade nós não somos membros da família, nós somos um empregado para eles.

$[\ldots]$ 
Maria: Quando eu era adolescente?

Moderadora: Você se sentia parte da família?

Maria: Não, eu não me sentia parte da família, entendeu?

Carol: Lembro quando eu morava na época em que eu cheguei aqui que eu via, não é? Assim, o carinho que eles tratavam as pessoas e eu ficava... Dava um ciúme, assim, em mim, em ver que eu não tinha, eu queria ter aquele carinho, assim, ter o meu pai, minha mãe perto de mim, meus irmãos. Eu sentia aquela vontade de poder também compartilhar, mas sabendo que não tinha essa oportunidade, não é? Dava aquela saudade quando chegava Natal que você queria estar com a sua família e não poder e saber que aquelas pessoas não eram o nosso ninho, a nossa família. Aí, era triste, não é?

Maria: Quando tinha ceia de Natal muitas das vezes... Porque, assim, se nós fossemos tratadas mesmo como da família, nós estaríamos ali do lado deles. Tinha muitos Natais que a gente passava, ficava na cozinha às vezes sozinho, sem ninguém do nosso lado da nossa família. Então, eu acho, assim, que para eles nós somos da família quando nós cuidamos dos filhos deles bem, entendeu? Pra eles, assim, cuidou do filho deles, tá... Agora, mostrando para os outros, que era assim cuida do meu filho então ela é da família, agora para depois dentro de casa é diferente, entendeu? (CASA DA PATROA, grifo nosso)

Duas das participantes, Nanã e Maria, demonstram uma postura crítica acerca da questão, segundo a qual tratar bem não seria igual a ser considerado alguém da família. O Natal, momento familiar por excelência, é apontado como uma oportunidade de analisar as marcas dessa distinção. Por um lado, Carol se refere ao sofrimento por não ter o carinho e o amor dos pais, enquanto acompanhava os membros da família à qual trabalhava demonstrando afeto uns com os outros. O posicionamento como "vítima" é caracterizado, então, não como incorporação da ideia de ser parte da família como nuance de um reconhecimento ideológico, mas pelo sofrimento ao qual a adolescente é sujeita por não poder ser cuidada por seus próprios pais e parentes.

Por outro lado, Maria é taxativa ao afirmar que os patrões utilizam o argumento de que a empregada faz parte da família para passar uma imagem positiva à sociedade, de que tratam bem a empregada, e para dizer que valorizam o modo como ela cuida das crianças. Desse modo, ela marca uma distância clara entre aquele reconhecimento que é prometido e o que é efetivamente entregue. Sobre esse assunto, Honneth afirma que "um ato de reconhecimento é incompleto por 
assim dizer, na medida em que ele não leva a modos de comportamento que dão expressão real ao valor verdadeiro articulado no ato original”. (HONNETH, 2012a, p. 92, tradução nossa, ver também MAIA; CAL, 2014) A promessa de que a adolescente faria parte da família é entendida como falsa, já que não se concretiza em ações. A participante posiciona-se claramente crítica a esse componente ideológico do TID, demonstrando que ele não é tão implícito e que o papel dela na relação não é de vítima passiva, mas de quem tem clareza sobre nuances das operações de power over em torno do TID. De modo complementar, recorremos à perspectiva de Brites $(2000,2003)$. A autora afirma que as práticas de mulheres empregadas domésticas demonstram o caráter lúcido de suas ações. Ainda que efêmeras e, frequentemente, diminutas (ela cita, por exemplo, mesmo uma gargalhada em certo momento), elas revelam que a desigualdade social na qual vivem as trabalhadoras domésticas não faz com que sejam alienadas ou que vivam num mundo de ilusões acerca do universo desse tipo de trabalho.

Essa condição evidenciou-se, sobretudo, nos grupos focais mais jovens. Na discussão no grupo das meninas atendidas pelo projeto social, uma adolescente, Erizinha, de, então, 12 anos, que trabalhou de doméstica na casa da avó materna desde os quatro anos de idade, afirma que, mesmo tendo relações consanguíneas, não se sentia parte da família:

Moderadora: Quando vocês trabalharam como babá ou com trabalho de casa vocês se sentiam da família ou era uma coisa separada?

Michelle: Eu não.

Erizinha: Eu não me sentia da família. Quando eu morava com a minha avó, eu não sentia isso. Me sentia uma escrava mesmo.

Michelle: É o que eu digo logo, eu me sentia uma intrusa naquele meio, e é o que eu era, só trabalhava lá.

Lecka: É verdade. Não me sentia da família, porque se eu fosse da família eu não ficava só eu, lá, fazendo as coisas, e os outros sentados em um canto só olhando. Ah! Eu não era da família não!

Alicinha: Você trabalhava de que Lecka?

Lecka: Babá e doméstica (PROJETO SOCIAL, grifo nosso)

Nesse grupo, o mais jovem, não há nenhuma corroboração ao entendimento de que a menina doméstica pode ser considerada parte da família, até mesmo 
num caso em que a menina Erizinha o é de fato. A medida entre ser ou não da família, então, não se resume a laços de sangue, mas ao modo como aqueles sujeitos se sentem naquele ambiente, a ponto de a neta se sentir uma "escrava" na casa da avó. A distinção entre a empregada e os membros da família também é embasada na distribuição de serviços domésticos. A postura crítica sobre esse aspecto do TID as afasta da ideia naturalizada de que as agregadas ou trabalhadoras infantis domésticas seriam membros da família para a qual trabalham. Acerca desse ponto, apresentam-se “desprovidas de ilusões”. (BRITES, 2003)

Na perspectiva das afetadas, a lógica opressiva segundo a qual a atividade que elas realizam não seria "trabalho doméstico", e sim apenas uma retribuição por ser parte da família, é largamente questionada. Nesse sentido, o posicionamento como "vítima" exposto pelos jornais em relação ao que seria uma percepção enganosa do pertencimento à família empregadora ganha contornos mais problemáticos e nuançados nas discussões dos grupos focais. Ao invés de se posicionarem como sujeitos que internalizam o que seriam os pressupostos da dominação (como apontado pelos media), a maioria das entrevistadas demonstra clareza sobre o que as faz empregadas e não membros das famílias para as quais trabalham e coloca em xeque esse ponto de vista opressivo, apresentando experiências e contra-argumentos que o contradizem. Mesmo as participantes que inicialmente se consideravam parte da família, como Tamires e Wanderléia, concordaram ao final da discussão que havia uma diferença significativa entre quem era da família e quem era a trabalhadora doméstica ou agregada.

TRABALHO INFANTIL DOMÉSTICO COMO PRÁTICA ESCRAVIZANTE

No curso dos grupos focais analisados, o TID foi, por vezes, considerado uma forma de escravizar crianças e adolescentes. Mas o que define o TID como escravidão nas falas dessas meninas e mulheres? Qual a relação entre escravidão e TID para elas? Como esses entendimentos são marcados por relações de poder e de que maneira as desvelam?

O TID como um todo, ou ainda práticas relacionadas a ele, como pouca oferta de alimentação ou ainda as longas jornadas de trabalho, foram considerados escravizantes pelas meninas e mulheres entrevistadas. Contudo, os sentidos que elas atribuem à escravização são distintos. No grupo “casa da patroa”, uma das 
participantes considera que dormir no emprego é uma forma de ser escravizada pelos patrões, o que provocou discordâncias:

Carol: [...] E eu não sei porque muitas pessoas sempre pedem para as pessoas para dormir, para morar [...] A maioria das pessoas pede para as pessoas para morarem no emprego, acho que justamente para escravizar a pessoa. [risos]

Maria: Não, aí no teu ponto eu não concordo contigo.

Nanã: Porque, assim, eu trabalho em uma casa e, por sinal, é uma casa muito grande, sou eu e uma outra menina, eu durmo no meu emprego, mas eu não me sinto escravizada, no meu emprego eu sou bem tratada é... Durmo a hora que eu quero dormir, por exemplo, assim não vou dormir largar o trabalho e vou dormir, não, mas eu durmo cedo, acordo cedo, vou fazer as minhas coisas para eu terminar cedo, posso assistir televisão, ler jornal. [...]

Maria: E eu discordo com a Carol pela forma dela falar que a gente dormindo no trabalho é uma forma de se escravizar... [...] Em uma das casas que eu trabalhei eu dormia na casa, teve casa que eu folgava de quinze em quinze dias, tinha vez que eu passava até mês para eu ir em casa, mas eu nunca fui explorada e nem escravi$z a d a$, pela forma de eu dormir. Até hoje eu durmo, entendeu? E até prefiro dormir no trabalho do que eu ficar em casa e ter de vir todos os dias porque assim eu acho mais cansativo, entendeu? Umas pessoas que me tratam bem, cuidam de mim...

Moderadora: Até quando tu eras adolescente, Maria?

Maria: É, quando eu era adolescente, quando eu era adolescente mesmo chegou um ponto de eu trabalhar que eu assim... Eu só folgava de quinze em quinze dias e tinha vezes, essa época de verão, esse negócio eu ficava um mês e quinze dias, não é? É... Sem ver a minha família, eu passava todo esse tempo longe da minha família. Aí, com tempo, as coisas foram mudando, entendeu? [...] Até porque eu também nunca deixei as pessoas me tratarem assim. Trabalho na casa de família, faço o que eu tenho que fazer, mas nunca deixei ninguém me explorar. Eu não vim pra cá para ser explorada e nem para as pessoas me tratarem assim, entendeu? (CASA DA PATROA, grifo nosso)

Para a participante Carol, morar no emprego é dar margem para ser escravizada, como ela apresentará no desenrolar do grupo, em razão das longas jornadas, por a menina ter que ficar sempre à disposição dos patrões e também porque, no caso dela, especificamente, houve uma tentativa de estupro por parte de um dos patrões quando ela era adolescente e morava em uma casa de família. 
Entretanto, para as outras participantes desse grupo focal, afirmar que o fato de morar na casa dos patrões aproximava o trabalho infantil do escravo soou como uma ofensa, já que elas, desde quando saíram do interior do Maranhão para Belém, aos 13 anos, moram nas casas em que trabalham.

Nesse sentido, a relação entre morar no emprego e ser escravizada aparece como uma ofensa em razão de a condição de escravo e o trabalho realizado por esse sujeito não serem considerados dignos de valor. Se, por um lado, Carol posiciona as trabalhadoras infantis domésticas como vítimas, assujeitadas por morarem com os patrões e estarem sempre disponíveis para servi-los, as outras entrevistadas não se reconhecem nesse lugar, o que provoca desconforto. A identificação do lugar que cabe ao sujeito escravizado é construída pelas ex-trabalhadoras infantis domésticas num movimento complexo de aproximação e também de distanciamento. Tanto que Maria procura, inclusive, agregar valor positivo ao fato de morar na casa em que trabalhou. Como argumentos para dissuadir a opinião da colega, Nanã e Maria afirmam que a medida de não ser “escrava” é o fato de ser bem tratada pelas famílias empregadoras e ter tempo para atividades de lazer (consideradas por Nanã como assistir à televisão, ler jornais ou dormir).

Questionando o posicionamento de "vítima” atribuído por Carol, Maria considera positivo o fato de dormir no trabalho, o que, segundo ela, tornaria a rotina menos cansativa por não ter necessidade de deslocamento. Por outro lado, quando indagamos o que ocorria quando ela era adolescente, ela afirma que chegava a ficar sem ver a família durante longos períodos, mas reforça o seu posicionamento como "resistente" na medida em que conseguiu mudar essa realidade com o tempo e que nunca permitiu que a tratassem mal.

Embora a escravização seja uma forma de dominação, a discussão acerca desse assunto nos grupos focais gerou pelo menos dois tipos de postura como "resistentes": uma efetiva, relativa à constituição de uma ideia de exploração à qual a pessoa não se deixa submeter; uma crítica, que reconhece a situação vivida no TID como grave exploração, porém apresenta atualmente um olhar questionador em relação ao passado.

Além da conceituação de escravidão como maus-tratos à adolescente trabalhadora apresentada nos grupos focais, há ainda a relação com a oferta de alimentação, que possui fortes conotações históricas e culturais. Como afirma Scarano, ao reconstruir parte da história da criança no Brasil no século XVIII, "em relação à questão alimentar e aos cuidados necessários para uma vida 
sadia, vemos uma preocupação maior em relação aos cavalos do que aos escravos”. (SCARANO, 2007, p. 120) Contemporaneamente, o controle da comida da trabalhadora infantil doméstica pode ser uma forma de tornar presentes relações de poder como power over. Ainda no grupo "casa da patroa", discute-se a exploração por parte dos patrões, e Nanã relata que já passou por dificuldades na casa de uma patroa que regrava a comida:

Carol: Olha tem casos que a patroa trata bem a adolescente, mas tem casos que não.

Nanã: [...] minha tia ela sempre, assim, ela procurou arranjar emprego com pessoas que ela achava que era legal. Porque se a gente chegasse em casa e falasse para a minha tia 'olha aconteceu isso, assado e feito', ela imediatamente ligava para as nossas patroas perguntava o que estava acontecendo e, assim, se a gente não estivesse gostando, ela nunca forçou a gente a ficar em um lugar que a gente não estava gostando, então sempre que aconteceu alguma coisa assim da patroa gritar com a gente [...]. Se a gente sentisse que a nossa carga horária de trabalho estava muito grande, que a gente não estava dando conta do emprego, ela sempre ia lá conversava com o patrão 'olha elas não estão dando conta então eu vou arranjar uma outra pessoa para você’ e pronto. E assim nunca forçou a gente a fazer uma coisa que a gente não queria, entendeu? Sempre nós que queríamos trabalhar, porque quando a gente veio pra cá, veio para trabalhar, a gente queria trabalhar e ela ajudou a gente a arranjar emprego, mas sempre procurou arranjar um emprego para a gente que a gente se sentisse bem. Mas eu já passei, sim, por coisas assim. Uma vez a minha tia arranjou um emprego para mim que, quando eu cheguei lá na casa dessa senhora, ela não estava em casa. Fiquei desde as três horas da tarde até onze horas da noite esperando ela lá sentada. Quando ela chegou, veio com um caderninho na mão e me falou 'o que eu comesse ia ser anotado que era para eu pagar, o sabonete que eu usava eu tinha que pagar, tudo eu tinha que pagar', o pão que a gente comia era de três, quatro dias que ficava no congelador. E aí, nessa época, eu tinha uns quinze, dezesseis anos, não sei, e nessa época não tinha telefone assim para gente ligar e o telefone na casa da minha tia tinha, mas só que na casa dessa senhora era na chave o telefone, não podia ligar, então eu fiquei quinze dias lá e, quando a minha tia me viu, ela pegou um susto, porque hoje eu estou muito gorda, mas eu sempre fui forte não era que eu era gorda mas eu estava seca, seca e amarela, e minha tia pegou um susto e falou 'o que está acontecendo contigo que tu estas desse jeito?', aí eu fui contar para ela e imediatamente 
ela pegou o telefone e ligou para essa senhora e falou que eu não ia mais voltar para lá porque se era para eu ser maltratada era melhor eu ficar perto dela, que se eu passasse fome era perto dela e aí eu não voltei mais para esse emprego [...].

Carol: A vantagem dela é que ela sempre teve o acompanhamento da tia dela, não é? Se não desse certo ela voltaria, tinha como ela ter contato, não é? Mas tem muitas pessoas que não tem esse contato com a família, tem pessoas que vêm para um certo lugar para uma cidade e não tem acompanhamento de ninguém, não conhece ninguém e fica aqui e só Deus mesmo para estar com a pessoa, guardar a pessoa, porque não tem uma família, nenhum amigo e a pessoa fica presa mesmo naquele local até o momento para conseguir falar com alguém que possa ajudar para tirar ela daquele local. (CASA DA PATROA, grifo nosso)

Nesse caso, a relação de power over da patroa sobre a adolescente se evidencia pela restrição do que a menina poderia ou não comer e também pela falta de liberdade de comunicação com a família. Percebe-se, assim, como uma prática diária e cotidiana pode ser objeto e fator de dominação. (ALLEN, 1998) Além disso, nessa situação, o power over ganha contornos explícitos de um conflito observável entre atores, de tal forma que um (a patroa) restringe as possibilidades e as oportunidade de outro (a doméstica), fazendo-a agir contra seus próprios interesses. (ALLEN, 2000; DAHL, 1957) Para Lukes (1980), para verificarmos relações de poder dessa natureza, é preciso examinar as decisões que os atores em conflito tomaram. Nesse sentido, esse modelo unidirecional de power over está ligado à capacidade de decisão de tal modo que quem decide, define o curso das situações de acordo com seus próprios interesses, causando prejuízos àqueles que domina. (PERISSINOTO, 2008)

Nesse caso, o lugar mais fraco é o da doméstica, que aceita as imposições e condições da patroa em relação à restrição de comida. O lugar atribuído a essa trabalhadora doméstica como sujeito sem autonomia ficava claramente demarcado quando a informante relata que as empregadas só comiam pão velho. Assim, a própria participante se situa como "vítima", cujo resultado da relação de dominação foi expresso no próprio corpo: “seco e amarelo”. Somente no dia de folga, 15 dias após ter iniciado nesse emprego, ela reencontra a tia, que é quem rompe com aquela situação e expressa à patroa a injustiça da condição na qual a menina se encontrava. Carol reconhece a vantagem de Nanã em ter esse porto seguro ao qual poderia retornar caso a experiência de TID não desse certo ou 
representasse algum risco de violência ou maus-tratos, o que a coloca em uma situação de distinção em relação às outras meninas trabalhadoras, que mudam de cidade e ficam sem ter com quem contar, a não ser com a família empregadora. Isso potencializa ainda mais o risco de exploração por conta de que a subordinação e a dependência dos patrões, principalmente, seriam maiores.

A resistência, ainda que presente na fala de Nanã, é impulsionada por um ator externo, a tia, que impede o retorno à situação de exploração. Porém, o modo como a entrevistada se refere a essa parente também indica uma relação de dependência e, de certa forma, dominação. Cabia à tia receber as meninas do interior do Maranhão e encaminhá-las ao serviço doméstico. Era ela que escolhia para quem as meninas iriam trabalhar e em quais condições. Esse tipo de aliciamento acabava gerando uma dívida de gratidão que nunca deveria ser esquecida pelas meninas encaminhadas ao serviço doméstico. É uma forma distinta do que ocorre com as “crias” (FONSECA, 1995; MOTTA-MAUÉS, 2008), mas ainda assim permanece um dever moral perante aquela tia, sob o risco de atos das meninas trazidas do Maranhão poderem ser caracterizados como ingratidão.

No grupo focal “condomínio", a participante Wanderléia também relata uma situação em que a patroa tentou restringir a quantidade de comida, porém a postura da, então, adolescente foi distinta da de Nanã:

Wanderléia: [...] No primeiro dia, reparei logo porque eu não via nada na cozinha, não é?

Tamires: É, 'eu vou trabalhar e não vou comer'.

Wanderléia: Demorou, mas chegou uma moça umas nove horas. [...] Estava lá na cozinha, aí eu fui lá tirar bronca de beber uma água. 'Ah! vou ficar por aqui'. O marido dela era uma pessoa super legal. As filhas os filhos, tudo pequeno. Aí ela mandava a empregada dela, a cozinheira, fazer o almoço. Não tem a coxa do frango, não é? [...]. A mulher adorava mandar a empregada torar a coxa de frango. Pra cá o tronco e para lá aquele cotozinho. Aí era um servido para cada pessoa, sabe? Aí ela: 'Wanderléia vem almoçar'. Então, eu não tomei café lá no primeiro dia porque eu levei meu pão e tomei café na casa de minha amiga [...]. Aí, uma colherzinha de arroz, um pouquinho assim de feijão, aí eu disse 'rapaz eu vou dar uma de ignorante, mas eu não vou comer isso'. 'Não vai almoçar Wanderléia?’. Eu disse: 'olha, dona Irene, a senhora me desculpe lhe dizer, mas na minha casa eu costumo almoçar, eu não vou sujar os meus dentes com esse pedacinho de frango'. E larguei tudinho e fui embora. E não fico mais. Não precisa da senhora me pa- 
gar, não, porque eu já estou indo embora almoçar na minha casa. E fui embora. Não, miséria comigo não passa também, [...] mas assim comigo não dá não. E não fiquei mais. Eu ia me matar, subir na escada para esfregar o telhado da mulher tudo, para ela me dar uma migalha de comida? Não, espera aí, não. Vou embora. Tá doida, é? (CONDOMÍNIO, grifo nosso)

Dentre as ex-trabalhadoras infantis domésticas e empregadas domésticas de modo geral, foi possível perceber que existe todo um conjunto de valores relacionados à oferta de alimento pelos patrões. Como se estivesse tacitamente colocado que, em troca do trabalho, por mais que haja algum tipo de remuneração, cabe aos patrões fornecer alimentação, e essa precisa ser de qualidade. Faz parte, então, do sentido de "ser bem tratada" no emprego doméstico, comer da mesma comida que a família empregadora e em quantidade suficiente. Entretanto, quando a adolescente está morando na casa da família e não tem contato com os parentes, ou não tem outro lugar para ir, questionar quando a comida é regrada se torna mais difícil. Ainda assim, no caso de Wanderléia, que tinha, nessa época, "dezesseis ou dezessete anos”, segundo ela, isso não foi um entrave para que ela criticasse abertamente a postura da possível patroa.

Subjazem à postura relatada por Wanderléia elementos de power to, na medida em que há o questionamento direto de uma forma de dominação materializada em relação à oferta de comida à adolescente doméstica. O gesto de Wanderléia indica um modo de resistência porque demonstra, não só o questionamento da dominação sob essa forma específica, mas a própria resistência ante a opressão com o pedido de demissão. É uma ação efetiva de questionamento, de desidentificação e de deslocamento do lugar que lhe fora atribuído.

No grupo focal vinculado a um projeto social, uma das participantes que havia trabalhado como doméstica na casa da própria avó afirma que o trabalho doméstico infantil é uma forma de escravidão, e isso gera discordância entre as entrevistadas, que procuram estabelecer uma distinção entre "escravidão" e "exploração":

Moderadora: Então, o que é esse tipo de trabalho [doméstico infantil]?

Erizinha: É escravidão.

Moderadora: Tu achas?

Erizinha: É. 
Michelle: Acha o quê?

Erizinha: Escravidão.

Michelle: Não, é uma exploração (risos). Não! Escravidão é uma coisa...

$[\ldots]$

Moderadora: E me digam uma coisa, por que tu achas que é escravidão e tu achas que exploração é diferente de escravidão? Me expliquem.

Michelle: Por quê? Ah, porque na minha opinião escravidão é uma pessoa que é muito escravizada mesmo. Mas exploração, não, exploração é uma pessoa que está sendo explorada ali, para mim não é a mesma coisa que [risos] na minha opinião é diferente.

Moderadora: O que vocês acham?

Lecka: $\mathrm{Eu}$ acho que a escravidão é quando a pessoa faz alguma coisa, trabalha sem receber o que tem para receber. Isso que eu acho.

Moderadora: $\mathrm{E}$ tu achas que este é o caso do trabalho de doméstica?

Lecka: Não, eu acho que não. O trabalho doméstico já é muito diferente disso, a gente vai trabalhar lá, a gente é explorada, mas a gente recebe.

Michelle: Não é tão escrava.

Lecka: É! A gente ainda recebe aquilo que a gente quer.

Michelle: E na escravidão a pessoa não recebe nem um real ela só recebe um prato de comida é água.

Lecka: E a água e mal.

Moderadora: E o que tu achas? Fala! Pode dar sua opinição

Erizinha: Não, tudo bem. Eu achava que escravidão e exploração eram a mesma coisa.

Moderadora: Ah é! Mas pode falar nas suas palavras, por que tu achas que o trabalho doméstico é escravidão?

Erizinha: Porque antes, quando eu morava com a minha avó no sitio, eu era escrava. Porque só eu que fazia as coisas, meus tios eram todos grandes e sempre me mandavam lavar as roupas deles. Aquilo lá, eu era escrava. E eu não recebia nada por aquilo e é a mesma coisa de exploração. Eles estavam me explorando e ao mesmo tempo estavam me escravizando. (PROJETO SOCIAL, grifo nosso)

De acordo com as entrevistadas desse grupo, haveria, então, uma gradação, uma escala que oscilaria entre ser bem tratada, ser explorada e ser escravizada. De tal forma que a medida da escravização seria receber apenas "comida e água" em troca dos serviços realizados. Ainda que as entrevistadas não esclareçam 
exatamente a distinção entre escravidão e exploração, fica o entendimento de que, na exploração, haveria algum tipo de pagamento ou remuneração, mesmo que insuficiente ("escravidão é quando a pessoa faz alguma coisa, trabalha sem receber o que tem para receber"). Elas reconhecem peculiaridades que não encaixam o TID exatamente como escravidão, mas também parecem insuficientes para encaixá-lo como simples exploração.

A questão é que, tanto sob a perspectiva da escravidão, quanto sob a da exploração, essas mulheres são vítimas, ou exploradas ou escravizadas. Entretanto, ser "explorada" é mais bem visto do que "ser escravizada", porque a primeira forma pressupõe um terreno maior para resistências, enquanto que a segunda não. Acerca desse assunto, Barros (2013) distingue o entendimento da "escravidão como diferença" e o entendimento da "escravidão como desigualdade". A partir de um olhar histórico, o autor afirma que foi esse último que permitiu toda atuação política em torno da abolição da escravidão, já que considerá-la como desigualdade marcava a possibilidade de que essa fosse superada, ao passo que o entendimento da escravidão como diferença não abria margem para esse tipo de transformação. Nesse sentido, posicionar-se como "explorada” representava uma capacidade maior de questionamento e resistência do que como "escrava".

A compreensão sobre o que caracterizava o trabalho escravo no TID foi mais bem desenvolvida nos grupos de mulheres adultas, empregadas de condomínio e também no grupo das senhoras ligadas à Cidade de Emaús e suscitadas, principalmente, após a apresentação do trecho da entrevista da advogada Celina Hamoy, que abordava esse assunto, publicada no Diário do Pará em 27 de abril de 2008:

É com certeza uma violência. [...] E a violação acontece principalmente pelo imaginário que existe na sociedade: 'Não, ela não está trabalhando, eu to ajudando, isso é tão comum'. Aí a menina começa a chamar a patroa de tia, de madrinha, começa a haver aquela troca: 'Tu me dá trabalho, eu te dou roupa'. Nada mais é e chega a caracterizar o trabalho escravo mesmo. (DIÁRIO DO PARÁ, 27/04/2008)

Moderadora: O que vocês acham disso? Vocês concordam, discordam?

Wanderléia: Esse caso aí é um trabalho escravo mesmo, porque, mana, tu vais trabalhar, trabalhar, trabalhar... ela te dá uma roupa, se ela quiser! Tu trabalhas 
dois, três meses para ela te dar um par de sapatos e um par de roupa.Tu trabalhas um ano inteiro para ela te dá, se você já for mocinha, para ela te dar uma bolsa, um vestido, um sapato.

[participantes falando juntas]

Karla: Um perfume, um xampu...

Tamires: Do pior!

Karla: Então, aí é um trabalho escravo porque é melhor você pegar seu dinheiro e comprar o que você quer, o que você precisa.

Tamires: Era a roupa, sapato, estudo, mas a roupa pouco vinha, o estudo porque tinha que ir todos os dias, não é? Mas a roupa, sapato essas coisas pouco vinham e o dinheiro, então, não tinha.

Wanderléia: [...] comigo era assim: se eu visse que os patrões eram bons, eu ficava. Se eu visse já notava logo no primeiro dia, no outro dia eu já não ia mais. E já não pegava se fosse para morar e, na primeira abertura da porta, eu já estava saindo. Uma vez eu fui trabalhar na casa de uma senhora ela disse: "tu trabalhas e eu te dou as coisas”. Trabalhei o mês todinho, começou o meio do outro ela não me deu nada eu disse, olha, na primeira abertura, fui embora. Porque eu morava com a Rai, minha irmã, e eu disse olha eu trabalho de graça para a minha mãe, mas para os outros não. (CONDOMÍNIO, grifo nosso)

Portanto, o ato de dar "as coisas" ao invés de pagamento é apresentado como um indicador de escravidão, ainda mais porque, em geral, o que recebiam eram produtos considerados de qualidade ruim. O "estudo", apesar de ser em escolas públicas, é também visto como uma forma de retorno da família empregadora ao trabalho desenvolvido pelas adolescentes, como na fala de Tamires. A crítica ao tipo de retorno que meninas envolvidas com o TID recebiam é corroborada ainda pelo relato de Wanderléia, que pedia para sair da casa quando as promessas não eram cumpridas. Desse modo, o trabalho "de graça” só era admitido para a própria família da ex-trabalhadora infantil doméstica ("trabalho de graça para a minha mãe, mas para os outros não").

No grupo “cidade de Emaús”, outro aspecto que relaciona o TID à escravidão é tematizado: o fato de os empregadores prometerem que os serviços a serem realizados pela adolescente seriam simples ou poucos em contraposição à realidade de quando se mudam para as casas de família e, gradativamente, novas funções são exigidas. 
Moderadora: E me digam uma outra coisa, o que vocês acham dessa idéia de relacionar o trabalho infantil doméstico com o trabalho escravo? Porque elas falam aqui nos cartazes... Que o trabalho infantil doméstico chega a ser um trabalho escravo, vocês concordam?

Acácia: É, porque é assim começa a lavar uma loucinha aqui, uma roupinha ali, quando pensa que não, a adolescente está fazendo todo o serviço do adulto. E tem muita gente covarde mesmo, tem gente que... Eu conheço pessoas que tem pena de dar quarenta reais, cinquenta para uma diarista fazer a faxina da tua casa. Prefere passar a sobrinha: 'não cada dia ela faz um pouquinho' não é? Então isso é escravizar. Então, esse que é o perigo da criança, da adolescente trabalhar no serviço doméstico é esse. Porque 'não, fulana é só para fazer companhia para a minha filha, só para levar a minha filha na escola'. É papo furado. Vai no supermercado, mana, eu conheço.

Duda: Um homem casado aqui de Belém, digamos assim, em uma cidade dessas aqui do interior, chegou lá ele viu um bocado de menina, aí ele conversa com os pais, não é? Não eu quero a sua filha, uma filha sua só para cuidar do meu filhinho, aí tá, a mãe acredita naquilo e deixa a menina ir não é? Quando chega aí começa, fazendo as coisas da criança, quando ela termina de cuidar da criança, de cuidar das coisas da criança ela já passa a fazer o serviço da casa. É como ela falou: no final de tudo isso aí ela já está fazendo todo o trabalho da casa, porque ela não quer pagar um adulto para fazer o serviço mais pesado. Então, isso aí, já acontece o trabalho escravo. (CIDADE DE EMAÚS, grifo nosso)

O argumento apresentado por Acácia é sustentado por conhecimentos advindos da experiência ("eu conheço"), o que a leva a constatar que a escravidão está ligada a falsas promessas e que ocorre por conta de empregadores não quererem contratar adultos para realizar esse tipo de serviço. A experiência dela é articulada, então, de modo mais genérico, com objetivo de afirmar que a escravidão, nos termos colocados pela informante, representa um perigo em potencial para meninas que fazem trabalho doméstico.

Em outro texto (MAIA; CAL, 2012), ressaltamos, a partir de Ikäheimo (2009), que a escravidão diz respeito a três danos, que guardam uma estreita relação com os discursos apreendidos nos grupos focais: (a) o primeiro refere-se à ausência de liberdade do escravo para escolher as atividades que ocuparão a sua rotina, ou, no caso estudado, ao modo como os serviços e tarefas impostos à menina doméstica vão, de acordo com os interesses dos patrões, tornando-se extensivos e 
intensivos. Como se referiu Acácia, começa com uma "loucinha" e termina com todo o serviço da casa; (b) o segundo refere-se ao modo como o senhor cuida do bem-estar do escravo, que o faz somente de forma instrumental, na medida em que ele precisa estar em condições de realizar satisfatoriamente as suas tarefas. O cuidado "instrumental” no TID é exemplificado por Nanã e Wanderléia, por meio da oferta controlada de comida e, por fim, (c) o terceiro ocorre "porque o trabalho não é livre, ele não conta como uma cooperação genuína e não produz a satisfação e a realização que a pessoa que trabalha livremente e altruisticamente pode receber na forma de gratidão dos outros”. (IKÄHEIMO, 2009, p.40 apud MAIA; CAL, 2012, p. 15) Nesse sentido, a analogia com o TID não passa apenas pela ideia de liberdade, mas, sobretudo, pela possibilidade de ter um retorno satisfatório do resultado do seu trabalho tanto em termos financeiros (e a crítica das entrevistadas foca nesse aspecto) quanto em termos de reconhecimento como sujeitos dignos de valor.

Para as mulheres doSindicato, o TID não propicia essetipo de reconhecimento:

Zezé: [...] Eu criei meus quatro filhos sozinha e sempre lutando. E eu acho assim, que eu não tive aquilo que hoje os meus filhos têm, os meus filhos e netinhos têm. É muito sacrificante, o trabalho doméstico. Olha, eu vou ser bem franca para vocês, eu não falo por orgulho para Deus não me castigar. Mas nunca mais eu voltaria para casa de família porque para mim foi a última gota, porque o trabalho doméstico ele é humilhante, ele é escravizante, entendeu? Por melhor que seja a patroa, mas por ele, ele não é um trabalho digno, você não tem direito a nada, não tem direito a espaço.

Moderadora: E quando é adolescente ainda?

Ericka: Aí não tem jeito nem o que falar!

Zezé: Adolescente ainda, não tem nem o que falar! Porque come o resto que sobrar... até hoje o trabalho doméstico em si ele é... [...] Não tem direito de brincar, de nada, nem de falar nada.

Ericka: Tirando que não brinquem com os filhos dos patrões, não e?

Zezé: E eu vou te dizer: até hoje, o trabalho doméstico... não tem uma trabalhadora doméstica que seja boa, se ela é... Ela nunca sai como uma boa trabalhadora, quando não é ladrona, é sebosa ou preguiçosa. Essa é a imagem do trabalhador doméstico. Você pode ter um bom trabalho de uma trabalhadora, mas quando ela sai que entra outra trabalhadora, você pode ver... (SINDICATO I, grifo nosso) 
Segundo Zezé, o TID e o trabalho doméstico em geral não são atividades laborais dignas de respeito, independentemente do perfil dos patrões. Quando a entrevistada diz que não tem direito a nada, ela se refere não somente a diferenças nas normas que regem esse tipo de trabalho e as que regem os outros, ${ }^{10}$ mas também a distinções empíricas, da ausência de privacidade, por exemplo, na casa dos patrões. Zezé argumenta, ainda, que nunca as domésticas são reconhecidas como boas profissionais, ou são vistas como "ladras", "sebosas" ou “preguiçosas”. Nessa fala, há referência ao preconceito e à discriminação racial na medida em que negros são tidos popularmente como "sebosos" ou ainda “preguiçosos”, desrespeitos que Zezé, por ser negra, sentiu na pele.

Acerca dessa adjetivação pejorativa das mulheres negras, Monteiro (2014) ressalta o quanto ela está presente na cultura popular e também na história e na literatura brasileiras: "os recorrentes estereótipos estampam o negro e se incorporam à história e à memória do grupo de geração em geração, como um patrimônio insuportável e insuperável da pertença”. (MONTEIRO, 2014, p. 76)

As meninas e mulheres entrevistadas reconhecem, na significação do TID, uma prática escravizante, a demarcação de inferioridade da trabalhadora em razão dos prejuízos ou danos (físicos, emocionais, à autoestima e ao autorrespeito) que esse sentido inflige a quem executa esse trabalho; tanto em razão das atividades que lhes são impostas, quanto pelo modo instrumental pelo qual o empregador considera a manutenção da trabalhadora doméstica. Soma-se a isso, a falta de reconhecimento de quem realiza esse serviço e a visão estereotipada e pejorativa que é endereçada às trabalhadoras infantis domésticas.

Frente a essas considerações, algumas participantes se posicionaram como "resistentes" por criticar a situação vivida no passado, ou ainda por relatarem casos de enfrentamento direto dessas. No entanto, de modo geral, não há uma perspectiva uníssona das afetadas acerca da relação entre TID e escravidão. Elas apontam indícios de como isso poderia ser percebido a partir da realidade em que viveram, porém se posicionar como "escrava” significava, para muitas delas,

10 Durante nossa pesquisa de campo, ainda não havia sido aprovada a PEC 66/2012, conhecida como a PEC das Domésticas. Ainda assim, e vamos argumentar melhor isso nas conclusões deste livro, apesar dos avanços em termos de busca por igualdade entre os trabalhadores domésticos e os demais, permanecem lacunas significativas. Além disso, entre a aprovação da PEC e a regulamentação da maior parte dos direitos que ela dispõe há um longo caminho. Outro maior ainda será necessário para fazer com a mudança na legislação se converta em transformações efetivas na vida das trabalhadoras domésticas. 
uma desvalorização de si e da atividade laboral que realizam. Em razão disso, elas procuraram destacar nuances desse processo de escravização no TID, mantendo em aberto possibilidades de resistência, ainda que em contextos de forte exploração.

Em contraposição, em matérias que fizerem referência à analogia entre o TID e o trabalho escravo, as afetadas pelo TID foram posicionadas quase que exclusivamente como vítimas passivas, que se sujeitam a condições de dominação, e o TID foi definido como uma situação de escravidão por conta de fatores como: a ausência ou da baixa remuneração, as condições mínimas de descanso oferecidas às meninas trabalhadoras, os castigos e maus-tratos aplicados contra elas, a realização de obrigações inadequadas à idade das adolescentes e ainda por haver uma troca de força de trabalho por roupas ou outras benesses.

TENSÕES ENTRE AJUDAR, “REPARAR MENINO” E TRABALHAR

Parte da dificuldade em politizar o TID é resultante do modo como ele é definido e referido socialmente. Discursos como "só está dando uma ajuda" ou "é somente para reparar menino" prejudicam a percepção dessa prática como atividade laboral de fato, tanto que fez parte do enfrentamento a esse tipo de trabalho infantil, a construção da expressão “Trabalho Infantil Doméstico”, cujo caráter político ressaltamos no segundo capítulo.

Nos textos dos media investigados, o termo "ajuda” foi utilizado preponderantemente para criticar esse entendimento acerca do TID, apontado como um discurso opressor, que maquia essa prática considerada um crime. De modo semelhante, "reparar" criança também foi utilizado com uso de aspas para marcar a distinção entre o relato que uma adolescente fazia de sua história e o que ela realmente teria vivido na perspectiva dos media, alimentada sobremaneira pelas organizações sociais. Neste subtópico, interessa-nos examinar como meninas e mulheres afetadas nominaram essa prática e como dialogaram com as percepções de que se tratava de um caminho natural para crianças pobres.

No grupo “cidade de Emaús", constituído pelas senhoras de maior faixa etária, a ideia de que esse trabalho infantil era um direcionamento natural para meninas pobres foi questionada por meio do reforço à necessidade de as crianças permanecerem, mesmo em condições adversas, sob a tutela dos próprios pais. 
Moderadora: Vocês acham normal meninas saírem do interior para irem para casa de família? É algo natural?

Lulu: Eu não acho normal, não.

Tati: Olha, dependendo da situação, se tem como ela trabalhar na casa dela ajudando os pais dela na casa dela, então é bem melhor ainda que ela durma mal dormida e coma mal comida, mas é bem melhor na casa dos seus pais. (CIDADE DE EMAÚs, grifo nosso)

Na verdade, não há uma discussão acerca do trabalho da menina propriamente, mas sim sobre para quem a criança ou adolescente deve trabalhar. Se houver condições, o ideal, segundo a participante Tati, é que a menina trabalhe junto aos pais. Frente aos perigos relacionados ao TID - o que preocupou bastante esse grupo foi o estupro por parte dos patrões em razão de algumas ex-trabalhadoras terem passado por situações de abuso ou tentativa de abuso -, o mais adequado é que a criança ou adolescente permaneça com os pais ainda que em condições pouco favoráveis - que coma ou durma mal.

Entretanto, esse não foi um consenso na perspectiva geral das afetadas. No grupo "casa da patroa”, houve uma defesa do entendimento de que se trata de um caminho natural para as meninas pobres. Isso porque, na argumentação de Nanã, é o emprego mais palpável e mais digno para as meninas pobres em contraposição à prostituição, por exemplo. Com objetivo de defender seu argumento, Nanã reforça a ideia largamente utilizada para sustentar o TID de que seria uma forma de ter sucesso e se tornar "alguém na vida", na medida em que seria possível, segundo ela, conciliar estudo com esse tipo de atividade.

Moderadora: Vocês acham o trabalho infantil doméstico normal? É algo normal? É algo esperado para meninas pobres, por exemplo?

Nanã: É, para meninas pobres sim, porque é o emprego mais fácil que a menina encontra. Porque, assim, tem muitas meninas que acham oportunidade de se prostituir, no caso entre a prostituição e o doméstico, é melhor optar pelo doméstico, porque é uma coisa digna, vai trabalhar ali, vai ganhar o seu salário e, no caso, em vez de ir para a prostituição e vir para o doméstico, no meu caso, eu acho melhor vir para o doméstico, não é? Para as meninas pobres porque hoje muitas meninas precisam trabalhar de doméstica desde cedo, devido a isso, querer ser alguma coisa na vida, porque a gente pode conciliar o trabalho doméstico com 
o estudo. Tem muitas pessoas hoje em dia que aceitam isso, a pessoa conciliar o trabalho doméstico com o estudo, então é isso. (CASA DA PATROA, grifo nosso)

Apesar de a própria história de vida apresentada por Nanã contradizer a ideia de que o TID é uma forma de crescer na vida, ela sustenta esse discurso. Ainda que o TID seja apresentado como uma vantagem ou possibilidade de resistência da menina trabalhadora a outros modos "não dignos", segundo a entrevistada, de "ganhar a vida", a forma como ela o justifica acaba por reforçar relações de dominação tácitas porque toma por base as promessas impulsionadoras do TID (chance de ser alguém na vida, melhores condições de estudo), mas que, em geral, são falsas, como a própria participante irá explicar mais adiante na discussão nesse grupo focal.

O tipo de power over que alimenta essa perspectiva é de caráter estrutural, que cerceia oportunidades de meninas de classes mais baixas, principalmente de municípios do interior, em que a única saída para a condição de pobreza que vivenciam em seus lugares de origem seja o TID na capital. Apesar das críticas a esse tipo de trabalho, evidenciadas, por exemplo, na discussão sobre restrição da alimentação, é atribuída dignidade ao TID em comparação à prostituição.

Ainda assim, a referência ao TID ocorre claramente como um trabalho. "É o emprego mais fácil”, um trabalho digno que propiciaria um salário. Provavelmente, o fato de receber um salário mínimo desde que começou a trabalhar aos 13 anos de idade reforçou em Nanã a percepção do TID como um "trabalho" efetivamente. Nanã e Maria, que foram encaminhadas ao serviço doméstico por meio de uma tia, como discutido anteriormente, eram as únicas entrevistadas que ganhavam um salário mínimo quando trabalharam na adolescência. De acordo com Nanã:

Nanã: [...] ela [a tia] sempre disse pra gente que se a gente ia trabalhar o mês todo na casa dos outros, então era pra a gente ganhar um salário e ela sempre conseguiu emprego pra gente para ganhar um salário. Quando eu tinha 13 anos o meu primeiro emprego, eu cuidava de toda uma casa e de duas crianças, mas eu ganhava um salário lá. (CASA DA PATROA, grifo nosso)

Chama atenção a quantidade de trabalho atribuída a uma adolescente de 13 anos, que não poderia, de acordo com a legislação brasileira, de modo algum, estar cuidando de uma casa e de outras duas crianças pouco mais novas do que 
ela, ainda que recebesse como pagamento um salário da época. Nessa perspectiva, o entendimento acerca do TID é afastado da ideia de que seria uma forma de ajuda mútua:

Moderadora: E me digam uma coisa assim, vocês acham que o trabalho infantil doméstico pode ser uma forma de ajudar uma pessoa conhecida? É uma ajuda mesmo ou é um tipo de trabalho mesmo? Porque tem muita gente que diz assim 'ah! não ela só está me ajudando, não é trabalho, a menina não está trabalhando, ela está me ajudando' [...]

Nanã: Não, sempre é trabalho porque, assim, às vezes, a pessoa, por exemplo, eu chamo a Carol para vim para a minha casa, vou na casa da mãe dela peço, no caso ela é minha afilhada ou sou tia dela eu tenho uma condição melhor e eu digo 'me dê Carol para vim morar comigo, ela vai me ajudar, não vai fazer quase nada', porque é o que sempre dizem 'não vai fazer quase nada, vai só me ajudar'. E quando chega na minha casa eu digo para ela 'você vai fazer a comida, limpar a casa eu vou ali rapidinho e volto' e quando eu chego já está tudo pronto e aí vai dias após dias, então sempre é trabalho, por mais que a pessoa diz que é só para ajudar, mas sempre a pessoa está trabalhando.

Carol: Tem casos que algumas pessoas... No caso, chamam a pessoa para ajudar, não é? Eles querem ajudar, mas a maioria dos casos não acontece para ajudar e sim para trabalhar mesmo. (CASA DA PATROA, grifo nosso)

Nota-se que a promessa de que a adolescente ficará com poucas responsabilidades na casa é amplamente questionada pela participante Nanã, apesar de, no momento anterior, ela ressaltar as potencialidades do serviço doméstico para crianças e adolescentes pobres. Na verdade, em relação a poucas oportunidades efetivas para meninas pobres, o TID se apresenta como uma alternativa concreta em razão de ser um caminho já trilhado por outras que as antecederam, como uma promessa que parece crível num determinado sistema de crenças, o que contribui para alimentar o componente ideológico do reconhecimento (HONNETH, 2007, 2012a; MAIA; CAL, 2014), por vezes, atribuído ao TID.

Pelo modo como se referem à ideia de o TID ser somente uma "ajuda" ao invés de trabalho, as entrevistadas denunciam o componente ideológico que tenta fazer crer que as atividades e os esforços empreendidos por meninas não se configuram como atividade laboral. Assim, compreender o TID como uma "ajuda" contribui para desvalorizar o trabalho realizado e a trabalhadora que o 
executa, pois desonera os patrões da necessidade de pagamento e impõe à adolescente um lugar ambíguo, em que ela não é nem a empregada nem uma pessoa da família.

Outro discurso por meio do qual o TID é suavizado como labor, é o que, na verdade, a criança ou adolescente está apenas "reparando” a criança. No grupo "condomínio", Tamires contou: "Comecei trabalhar com oito anos. Vim do interior para trabalhar na casa de família, mas assim para reparar criança, serviço de acompanhante para criança, reparar enquanto a mãe saia, costurava, fazia essas coisas [...]". Ainda que a entrevistada inicie sua fala fazendo uso do verbo "trabalhar", logo em seguida ela argumenta que era um "serviço de acompanhante de criança”, para "repará-la” na ausência da mãe.

As adolescentes do "projeto social" apresentaram uma postura mais crítica acerca desse assunto, ao mencionar que esse pode ser apenas o começo de um processo de exploração no serviço doméstico, porque elas começam "reparando” criança e, aos poucos, vão sendo incumbidas de outras tarefas.

\begin{abstract}
Alicinha: Porque quando a gente vai para a casa da pessoa qualquer criança se a gente for reparar, você tem uma coisa para fazer, não é? Você tem que fazer comida, tem que fazer a merenda pra ela, varrer a casa, tem que limpar lá, lavar a louça suja que a gente usou.

Michelle: Na maioria das vezes a pessoa fala assim 'procura-se uma babá'. Babá! Babá é para cuidar da criança e não para fazer as coisas domésticas, porque quando a gente chega lá: 'ah! tem uma louça ai pra tu lavar', aí tu vai lá e lava, aí fica naquela coisa. Ela disse que era babá para reparar criança e não para fazer as coisas de casa. Na casa da tia dela [aponta para a Lecka], não é? Fui reparar as primas dela, aí toda vez que chegava lá tinha louça na pia e ela dava só trinta reais por semana e ela falava que era para a gente reparar as crianças. Mas ela queria que fizesse de tudo na casa dela. Eeu: 'Eu? Me matar por causa de trinta reais pra mim fazer tudo? Ah! Se eu não morro de fome, não mesmo vou passar necessidade, não estou precisando disso'.
\end{abstract}

Alicinha: E ainda por cima lavava a louça não é?

Cris: É, é verdade.

Lecka: Mas eu reparava, pois a titia tinha que trabalhar. Ela também trabalhava não tinha ninguém para ficar lá também, neste tempo eu também nãofazia nada, nãoé? 
Moderadora: Eu ia perguntar para vocês se vocês acham que o trabalho de reparar crianças é melhor do que o trabalho de cuidar da casa?

\section{Todas falam juntas: Não!}

Michelle: Não, melhor o mesmo é o serviço de casa. Criança dá muito trabalho! Ás vezes a criança é muito, muito chorona. Às vezes é mal ouvida, aí a gente não pode bater porque é filho dos outros. Não é seu filho e você não pode fazer nada, tem que ficar ali aturando. Casa não, tu faz ali a louça não vai brigar não vai te fazer nada [risos].

Alicinha: Não vai ter nada empatando lá nessa hora. A criança às vezes a gente vai lavar louça a criança vem com o pé, ou está chorando. Ou está querendo aquilo que a gente realmente não pode nem dar. Ela está querendo aquilo e a gente não pode. Ai fica um choro, uma gritaria aí tem que ficar aguentando e eu não tenho paciência. (PROJETO SOCIAL, grifo nosso)

Michelle relata que já passou pela situação de ter sido chamada para "reparar” criança e explica o mecanismo a partir do qual a menina passa a acumular mais tarefas: a família começara a deixar louças também para a adolescente lavar e, dessa forma, outros serviços domésticos. Na opinião das adolescentes, lavar louças é apontado como o estopim desse processo: "E, ainda por cima, lavava a louça, não?!”. Elas criticam esse fato como indicativo da exploração, já que "babá” seria apenas para cuidar da criança e não da casa como um todo. Quando chegou nesse ponto, Michelle afirma que deixou aquela casa porque não iria se "matar por causa de trinta reais". A menina, então, assume um posicionamento resistente àquela forma de exploração, recusando-se a ceder à tentativa dos patrões de impor uma carga maior de serviço do que era esperado.

Por outro lado, a responsabilidade de cuidar daquelas crianças passou para a Lecka, que era parente daquela família. Ela justifica esse trabalho porque "não fazia nada” à época, reproduzindo, assim, uma das ideias que sustentam o TID: é melhor a menina estar trabalhando do que ficar ociosa.

É relevante observar como as adolescentes se mostram extremamente críticas ao trabalho de babá, porque exige muita paciência e a necessidade de lidar com crianças sem a possibilidade de reprimi-las porque são "filhos dos outros". De modo distinto, para as adolescentes do grupo "centro de formação", ser babá é visto como uma forma de ser estimada pela família da criança, inclusive, criando uma relação de dependência: 
Moderadora: Babá é diferente?

Tatá: Pra mim é, porque babá cuida da criança. Dá banho, fica reparando.

Nati: Doméstica não, porque faz as coisas da casa.

Lorrane: Aí ela já é tratada como uma pessoa da família pra criança já ir se acostumando, já.

Moderadora: E vocês acham que a babá tem mais respeito da patroa do que a empregada doméstica?

Lorrane: Sim porque, aí, no caso, né, os patrões vão depender da babá, porque... Quando acabar o tempo daquela babá, aí vão ver o quanto a criança vão sentir falta dela e vão querer chamar de novo ela.

Tatá: Não tem mais volta. Fazer com que a criança se acostume com a babá é apresentado como vantagem para esses sujeitos, constituindo uma forma de power to, um modo de resistência da menina trabalhadora doméstica frente à família empregadora, considerando que os pais não vão querer deixar os filhos sofrendo por conta dessa distância, o que, segundo elas, cria um vínculo e uma dependência dos pais em relação à babá. (CENTRO DE FORMAÇÃO)

Na pesquisa realizada por Brites $(2000,2003)$, a autora identificou uma forte relação afetuosa entre as crianças e as babás. As primeiras, principalmente no início da infância, expressavam o desejo de que a trabalhadora doméstica compartilhasse dos mesmos espaços que o restante da família, por exemplo, o conforto do sofá da sala. As últimas, por outro lado, ensinam às crianças, tarefas, práticas e conhecimentos do mundo subalterno. Segundo Brites, "Elas [as crianças] dialogam com as empregadas, ouvem suas histórias, escutam a mesma música no radinho de pilha da cozinha, perguntam muitas coisas. Nessa intimidade cotidiana, as empregadas podem assumir conscientemente o papel de transmissoras de conhecimentos”. (BRITES, 2000, p. 93-94) Nesse sentido, a babá exerce uma forte influencia sobre a criança, porém esse laço que é criado pode fazer com que ela, ao invés de estimular ações de power to - como informado pelas adolescentes do "centro de formação"-, sinta-se pressionada a se sujeitar a condições de trabalho desfavoráveis, como salários menores do que o mínimo instituído, para não correr o risco de ficar longe da criança que ama.

Entretanto, a mesma dependência pode ocorrer com as crianças, como ressaltado pelas adolescentes que ouvimos. Sobre esse assunto, Brites (2000) relata o caso de um menino que ficou doente quando o pai demitiu a empregada. Não se trata de uma situação isolada. Brites afirma "Ouvi variantes desse tema em 
inúmeros outros relatos, sublinhando uma intensidade de contato que não deixa de ter conseqüências importantes”. (BRITES, 2000, p. 93)

No caso do TID, as adolescentes do grupo "centro de formação” ressaltaram esse segundo viés da dependência (criança > empregada) como um espaço de resistência e de possibilidade de imposição de certas vontades frente aos patrões. Contudo, quando questionadas sobre o pagamento que uma adolescente deveria receber, uma das participantes afirma que, "Nesse caso eu acho que deveria pagar certo, mas não muito, porque muito dinheiro na mão de adolescente não é muito bom. Tem certos adolescentes que não sabem usufruir do dinheiro". O contraponto entre dar a ver modos de resistência no TID e, ao mesmo tempo, assumir um posicionamento desfavorável às adolescentes quanto ao valor a ser pago mostra indícios do que Biroli (2012) chama de "agência diferenciadamente imperfeita”, resultado da relação entre agência e constrangimentos sistemáticos que influenciam de modo diferenciado a forma como as mulheres se posicionam no mundo. Isso porque expressões como "dinheiro na mão de adolescente não é muito bom” refletem a internalização de um processo tácito de power over que alimenta a ideia de que não é preciso pagar o valor integral ao trabalho de adolescentes porque elas não saberiam como usá-lo - em parte porque não sabem, ainda, julgar o que é melhor para si -, ao mesmo tempo em que, na discussão anterior, elas demonstraram ser um modo de resistência atuar como babá, por exemplo. Como afirma Allen (2000), power over e power to (e também power with) não são tipos distintos de poder, mas nuances, matizes que se combinam de formas distintas no contexto de diversas práticas.

Uma mesma situação, por exemplo, pode ser vista pelas afetadas como resultante de operações de poder como power over ou como forma de resistência. No grupo do “sindicato", Zezé inicia uma discussão sobre os objetos e utensílios que os patrões doam às empregadas:

Zezé: Rose, deixa eu te falar uma coisa, sobre [coisa] dada de patrão assim... Moderadora: O quê que é?

Zezé: Dá, vamos supor, um objeto, não é? Ela [patroa] te ajudou? Ela não te ajudou, ela te pagou. Sabe por que ela te pagou? Pelas horas, pelos dias que você ficou... Patrão nenhum não dá nada para o trabalhador doméstico não. 'A minha patroa é boazinha. Ah! A minha patroa me deu um fogão, ela comprou um fogão e me deu o dela. A minha patroa comprou uma roupa nova e me deu a dela que 
ela usava. Minha patroa me deu isso me deu [...]'. Não! Ela não está dando ela está simplesmente compensando aquelas horas que você ficou na casa dela, que o certo ela deveria pagar em dinheiro, você entendeu? Então toda a vez que alguém chega para mim e diz assim 'Ah a minha patroa é muito boa comigo, olha lá ela me deu um bocado de roupas um bocado de sapatos que ela não usava'. Aí, me dá um aperto, assim, de ver tanta ignorância. Porque não é isso.

Rose: É verdade mesmo. Eu não tinha analisado isso...

Ericka: É verdade. Eu sempre tive isso comigo.

Zezé: Não é boa não! Ate por que acho que é uma maneira ate de humilhar a gente. Porque não é uma coisa nova da loja, é uma coisa que ela já usou.

Ericka: É humilhante.

Zezé: Ela não quer mais, então ela vai te dar.

Ericka: Pra não jogar no lixo!

Zezé: Pra não jogar no lixo. E ainda avisa assim: para não jogar fora eu vou te dar, tu queres fulano? [...]

Fofa: Eu acho que depende da pessoa. Porque os meus filhos, o pai deles morreu eu era muito nova, aí eu fui para a casa de família, não é? Eles foram criados praticamente... porque o que eu ganhava era pouco... Eu sou mãe e pai, praticamente usando as roupas dos filhos das minhas patroas. Então, eu aceito isso como se fosse uma ajuda, como se a pessoa estivesse me ajudando, não é? Porque eu não podia comprar, não é? Então, eu acho que depende da pessoa.

Rose: $\mathrm{E}$ muitas vezes também a gente fala mal, mas também tem muitos patrões que são bons, que, mas não são todos também não é? Mas primeiro eles perguntam você quer? Agora depende não é? Se a gente vai querer.

Zezé: A colocação é essa, você quer? Mas ela está sabendo que ela está te devendo, tu entendeu?

Ericka: É verdade. Os extras. (SINDICATO II, grifo nosso)Para Zezé, é um sinal de ignorância a doméstica afirmar que a patroa é boa porque dá objetos usados que não deseja mais para a empregada. Segundo ela, trata-se de uma desculpa para que não se pague todo o valor devido às empregadas domésticas, referente às horas extras e a outros benefícios os quais a doméstica, na opinião dela, deveria receber. Dessa forma, ela posiciona a doméstica como vítima de uma situação de power over internalizado, admitido como benéfico pelas próprias oprimidas, o que resulta, de acordo com Zezé, em ignorância e, em uma forma de humilhação implícita, já que o que está sendo oferecido à trabalhadora é o 'resto', aquilo que seria jogado no lixo ('para não jogar fora eu vou te dar, tu queres fulano?'). 
Entretanto, essa mesma situação é colocada de modo completamente distinto pela participante Fofa. Por meio do relato de experiências pessoais, ela modifica o enquadramento em torno desse tipo de doação, ao afirmar que aceitar coisas usadas da patroa é uma forma de resistir a condições estruturais adversas. Haugaard (2012) ajuda-nos a compreender essa perspectiva ao desenvolver a ideia de que relações de power over não podem ter sempre um resultado de soma zero. O autor defende que, se os pressupostos de relações de poder são sempre desfavoráveis para os sujeitos afetados, de modo que eles nunca tenham interesses contemplados, é improvável que essa relação se mantenha. Segundo ele, "você pode enganar as pessoas por algum tempo, mas não todo o tempo". (HAUGGARD, 2012, p. 25, tradução nossa) De modo complementar, também recorremos a Brites (2003), para quem, nesse "trânsito de patrimônio", as empregadas fazem uso "do mesmo referencial ideológico dos patrões: retiram o melhor proveito da situação. Em troca devolvem-lhes servilidade, prestígio e amizade, completando o círculo de dádiva-dom”. ${ }^{11}$ (BRITES, 2003, p. 70) A partir desse contexto, a discussão sobre o ato de receber doações de objetos usados da patroa adensa e complexifica o jogo entre o poder como dominação e como resistência.

Na tentativa sanar o impasse na discussão acerca desse assunto no grupo focal, a participante Fofa individualiza a responsabilidade pela decisão de aceitar e desonera a patroa de uma tentativa de engano, porque indica que a patroa oferece os objetos à empregada, que os aceita se quiser. Contudo, como resposta, Zezé reenquadra o ato de doar como um modo de enganar a empregada, na medida em que a patroa sabe que deve benefícios à doméstica, mas oferece objetos usados como forma de pagamento.

TRABALHO EM CASA E NA CASA DA PATROA

O modo pelo qual essa temática foi abordada nos grupos focais variou em razão da idade e dos perfis das participantes. Por exemplo, entre as mulheres mais velhas, a referência do trabalho em casa, para a grande maioria, possuía uma

11 Brites explica, referenciada em Marcel Mauss, em que consiste o círculo de dádiva-dom: "Este princípio denuncia o desequilíbrio entre a abundância de uns a e pobreza de outros. 'A esmola é fruto de uma noção moral da dádiva da fortuna, por um lado, e de uma noção de sacrifício, por outro [...] a Nêmisis vinga os pobres e os deuses do excesso de felicidade de certos homens, que devem desfazer-se dela' (Mauss 1974: 66)". (BRITES, 2003, p. 76) 
profunda relação com o trabalho na roça, dos pais ou delas próprias. Para as mais jovens, sobretudo adolescentes, a realização de serviços domésticos em casa é uma obrigação, o que remonta a uma discussão sobre se somente as meninas devem ficar com essa responsabilidade ou se ela deve ser compartilhada com outros membros da família.

Após um processo sistemático de leitura e releitura das transcrições dos grupos focais, encontramos três subtemas relacionados ao trabalho em casa: a) trabalho na roça x trabalho doméstico; b) condições de trabalho em casa e na casa da patroa e, finalmente, c) tensões no trabalho em casa.

Em contraposição ao trabalho na roça considerado pesado e mal remunerado, o TID é tido como uma alternativa, principalmente pelas meninas que vêm de zonas rurais de municípios longínquos, como as que participaram do grupo "casa da patroa":

Moderadora: Por que a Nanã falou que tem diferença do trabalho no interior, que a capital é diferente do interior?

Maria: Fala aí, Nanã!

Nanã: Assim, porque a diferença do interior, porque no interior você não tem empregada doméstica, então, no interior, a gente trabalha mais, pelo menos na minha cidade o que os meus pais faziam era agricultura, então a gente trabalhava na roça, entendeu? É completamente diferente da casa de família, trabalhar como doméstica.

Maria: É mais cansativo.

Moderadora: O quê? A roça ou trabalhar em casa de família?

Maria: A roça. Deus me livre!

Moderadora: Vocês trabalhavam na roça também?

Carol: Não, não.

Maria: Eu nunca trabalhei.

Nanã: Eu trabalhei. Até os 13 anos eu ajudava os meus pais na roça porque meus pais até hoje trabalham na roça.

Moderadora: Plantando o quê?

Nanã: Milho, mandioca, arroz, feijão, essas coisas assim.

Carol: Mas também, porque lá também, na cidade de lá também eles não pagam muito bem, não é? O que eles pagam é muito pouquinho e às vezes nem pagar, eles não pagam se nós ficarmos lá. E aqui [na capital] já não. Tem casos em que já vão pagar melhor. Entendeu? 
Moderadora: Então vocês... Comparando o serviço doméstico com o serviço na roça, vocês acham que o serviço doméstico é...

Nanã: É melhor.

Carol: É muito melhor.

Maria: Pra mim, é, porque eu... Eu sempre vi a minha mãe trabalhar na roça, assim. É cansativo. Naquele sol, não tem hora, só toma café e vai trabalhar. Para meio-dia para almoçar e vai trabalhar de novo. Então, para mim, no meu ponto de vista, trabalhar na casa de família, a gente acorda cedo, faz as nossas coisas, quando termina de fazer as coisas, a gente vai descansar, entendeu? A gente para pra descansar e só retorna no outro dia. E na roça não, é mais cansativo, apesar que eu não trabalhei, mas vendo a minha mãe trabalhar. (CASA DA PATROA, grifo nosso)

A situação de trabalho na roça é tão temida por quem acompanhou os pais nessa situação ou por quem efetivamente desenvolveu essa atividade na infância, como é o caso de Nanã, que a ida ao serviço doméstico configura-se uma vitória, a possibilidade de obter algum pagamento, ainda que não seja integral, e uma alternativa para ter uma vida menos cansativa. Nesse sentido, de modo complexo, a própria saída da casa da família para o serviço doméstico na capital pode se configurar como uma estratégia de resistência a condições precárias de vida nos municípios de origem. Apesar de todos os problemas do serviço doméstico anteriormente apontados pelas participantes, ainda assim, elas afirmam preferir essa ocupação ao trabalho no roçado.

Essa posição é corroborada pelas participantes do grupo “condomínio”:

Moderadora: E vocês me disseram que já tiveram experiência de trabalho na roça, na lavoura, qual é o melhor tipo de trabalho? Na roça ou o trabalho doméstico para uma criança ou para uma adolescente?

Tamires: Para mim era o trabalho doméstico. Na roça a minha mão ficava toda doendo, tudo esfolado.

Wanderléia: É, e na roça, é chuva, é sol...

Tamires: É.... É chuva, é sol, é lagarto, é cobra, Ave Maria!

Wanderléia: Aquelas folhas do arroz, do milho, molha e faz uma coceira, que eu vou te contar.

Tamires: Doméstica é melhor.

Karla: Eu prefiro doméstica do que a roça. 
Wanderléia: Era melhor quando eu comecei a cuidar do garoto, que eu já te falei que hoje em dia deve ter seus 28 pra 30 anos. Eu já tenho quarenta e um. Quando eu fui trabalhar lá na casa desse prefeito, parecia assim que eles me cobriram de ouro, porque, eu vou te contar, eu penava muito na roça. E se não fizesse direito, ainda apanhava. A mamãe ainda batia quando a preguiça era demais.

Tamires: De roça, eu nunca apanhei da minha mãe. Ela ainda dizia 'vai minha filha fica ali na sombra'.

Wanderléia: A mamãe dizia, mas, tinha a hora certa para ela dizer: 'fica ali'. Era naquele sol de onze horas a onze e meia.

Tamires: A mamãe falava também desse sol.

Wanderléia: Mas, antes disso, a gente tinha preguiça, eu era uma... Socava na enxada, escorava em cima e ficava, quando ela vinha de lá era só uma [porrada]. Aí, Ave Maria! Não gosto nem de pensar nisso mais [...] (CONDOMÍNIO, grifo nosso)

A cena que elas constroem sobre o trabalho na roça é mais nuançada e ressalta dois pontos que ainda não haviam sido colocados: a obrigação de trabalhar na roça e as punições que sofriam da mãe quando faziam "corpo mole" por estarem cansadas. Ao mesmo tempo, relatam certo cuidado de algumas mães ao "dispensarem" as crianças do trabalho no horário em que o sol estava mais forte.

A participante Wanderléia apresenta um forte descontentamento em relação aos atos de violência cometidos pela mãe ("Ave Maria! Não gosto nem de pensar nisso mais...”) ao ponto de afirmar que se sentia "coberta de ouro" pela família empregadora, para a qual ela, com, então, 13 anos, cuidava de um menino de oito, e só visitava a família de origem aos domingos, quando os patrões iam à zona rural. Nessa época, segundo ela, recebia apenas roupa, calçado, comida, "escola" e considerava suficiente esse pagamento por ser bem tratada pela família. No entanto, quando se mudou para outra casa de família, ela afirmou no desenrolar do grupo focal: "trabalho de graça para a minha mãe, mas para os outros não” (p. 204 deste livro). Embora sofresse com a imposição de trabalho na roça pela mãe e com a violência sofrida quando criava estratégias para evitá-lo (como descansar apoiada na enxada, por exemplo), ela considera legítimo trabalhar "de graça” para a própria família. Entretanto, no momento em que consegue mudar de atividade, sente-se satisfeita por não ter que passar mais por aquela situação.

As outras participantes defendem ainda a atuação no serviço doméstico como melhor do que da roça ao apresentar os perigos desse último, como exposição ao calor excessivo, às chuvas, a animais peçonhentos, entre outros. 
No grupo das participantes de maior idade, Lulu demonstra que preferiria trabalhar na roça e ficar perto dos pais ao invés de viver pela casa das outras pessoas. Já Acácia relata outro lado do trabalho da roça, quando a menina precisa cuidar da casa e dos irmãos enquanto os pais vão trabalhar no roçado:

Moderadora: Vocês trabalhavam na roça?

Acácia: Na roça, plantando feijão...

Lulu: Eu, quem dera, nunca tive carinho de pai nem de mãe. Fui criada pela casa dos outros não é? Aí...

Acácia: Era muita gente em casa. Eram oito mulheres e três homens. Aí botava só uma para fazer tudo. Era um quilômetro que a gente ia buscar. Dava oito quilômetros por dia. E a bacia de louça desse tamanho [a participante estica os braços para mostrar o quão grande era a bacia] que a gente botava em cima da cabeça e ia lavar lá no fundo do terreiro. Era só eu. As outras iam para o roçado e eu ficava sozinha...

Moderadora: Quantos anos tu tinhas? Tu lembras?

Acácia: Eu tinha, assim, uns dez, onze anos, doze anos por aí assim. Porque, assim, eu tinha que fazer porque saía tudo para trabalhar, mas quando chagavam em casa, estava tudo pronto, almoço pronto, tudo pronto, nem que não fosse bom, mas estava tudo pronto [risos]. (CIDADE DE EMAÚs, grifo nosso)

Ainda que fosse uma família numerosa, com onze filhos, era preciso que a maioria trabalhasse na roça para conseguir sustento para a família enquanto a uma das filhas eram destinadas as obrigações domésticas. Embora Acácia não se sujeitasse às duras condições do serviço no roçado, as responsabilidades que tinha também exigiam muito de uma menina com pouco mais do que dez anos. Somente para lavar a louça, era preciso andar bastante. Ainda que a quantidade de quilômetros indicada pela participante não seja exatamente correspondente à distância real, o uso figurado indica a lembrança do grande esforço que fazia para ter acesso à água e poder lavar a louça. Apesar disso, ela demonstra orgulho por conseguir dar conta das árduas tarefas ("mas quando chagavam em casa estava tudo pronto, almoço pronto, tudo pronto, nem que não fosse bom, mas estava tudo pronto").

A maioria das entrevistadas que vieram de municípios do interior e tinham proximidade com o trabalho no campo afirmou que o trabalho doméstico seria a melhor alternativa em relação àquele. No entanto, quando as participantes em 
geral comparavam as condições de trabalho doméstico nas suas próprias casas e na casa de terceiros, elas apontaram diferenças que tornavam o serviço doméstico desvantajoso.

Segundo as participantes, trabalhar em casa pode ser uma forma de ficar protegida do poder de mando e da humilhação dos patrões.

Moderadora: [...] O que é o trabalho doméstico?

Alicinha: Eu acho que é o que a gente faz na nossa casa. E quando a gente arruma algum trabalho assim, é o que a gente faz também na outra casa. Mas nem tudo é a mesma coisa, porque na nossa casa a gente faz uma coisa. Na casa dos outros a gente tem que fazer outras. Até melhor às vezes, para não chatear o patrão que se irrita.

Lecka: Às vezes eles se irritam e brigam muito com a gente. Falam com a gente que a gente não quer fazer nada, e que a gente não vai receber salário. Aí tem sempre esses negócios, então é melhor trabalhar na casa da gente do que na dos outros mesmo.

Cris: Na maioria das vezes, na casa dos outros é muito diferente do que na nossa casa, porque na nossa casa a gente faz na hora que a gente quiser, na casa dos outros não. Tem que acordar no horário certo, tem que estar pronto tudo cedo.

Michelle: Na minha opinião, trabalho doméstico, doméstico é isso? É quando a pessoa vai... É a mesma coisa como fosse na sua casa, vai trabalhar fazer as coisas lá, tudinho, aí depois volta no outro dia... Toda uma rotina que ela tem. Aquilo que ela tem que fazer todos os dias, todos os dias, como se fosse o trabalho que ela tem que fazer na casa dela. (PROJETO SOCIAL, grifo nosso)

O TID é considerado uma extensão, uma continuação dos serviços que a menina realiza na própria casa ("como se fosse o trabalho que ela tem que fazer na casa dela”), porém pressupõe mais obrigações e responsabilidades que implicam fazer todo o serviço que é solicitado e nos horários determinados. Além disso, o TID na casa de terceiros pode significar, segundo elas, a sujeição a condições de tratamento desrespeitosas e a relações de power over.

Sobre esse assunto, o grupo das mulheres ligadas ao "sindicato" mencionou outros motivos pelos quais o TID pode consistir num desrespeito.

Moderadora: Vocês acham que tem diferença entre o trabalho que a menina doméstica exerce em casa e o que ela faz na casa de família? 
Rose: Tem.

Zezé: Não.

Fofa: Tem sim.

Zezé: Não tem, não.

Nete: Tem.

Participantes: Tem muita diferença.

Moderadora: Vamos lá: por que sim, por que não?

Zezé: Porque é a continuação! É o meu ponto de vista. Se ela faz o trabalho em casa, na casa dela, ela vai continuar fazendo o mesmo que ela fazia na casa dela na casa de família. Tem a diferença porque não é na casa dela, é na casa dos outros.

Moderadora: $\mathrm{E}$ você?

Lenyta: Na casa dela ela pode fazer na hora que ela quiser, ela pode parar, descansar, e na casa de família não, a patroa está ali e ela está exigindo: 'Não você tem que fazer, tem que fazer agora, tem que fazer isso e isso'. Ela não tem tempo para descansar. E na casa dela ela tem para fazer o trabalho dela escolar, que foi o meu caso que eu falei ainda agora. Não tinha tempo para fazer os meus deveres de escola, por isso eu parei. Então essa é a diferença.

Rose: Tem coisa que ela não faz em casa que ela faz na casa do patrão. Por exemplo, na casa de pai e mãe, não querem passar a roupa, não querem tirar a louça. Na casa de patrão, já, tem que fazer tudo isso. É totalmente diferente.

Ericka: E fora a humilhação e o dinheiro que não sai certo como o pai e a mãe dá [...]. É muito humilhante porque tem horário para dormir, tem horário para tudo, até para comer e não tem descanso (SINDICATO II, grifo nosso)

Apesar da discordância inicial, que é apenas aparente, porque a participante Zezé, no final, concorda que há diferenças entre um tipo de trabalho e outro: “Tem a diferença porque não é na casa dela é na casa dos outros”. Ser "na casa” para menina trabalhadora quer dizer, segundo as participantes, que ela está a salvo de cobranças excessivas, de humilhações e com condições de estudar. Como contraponto, "o trabalho na casa dos outros" significa não ter tempo para descansar, nem para realizar as tarefas escolares e ter que estar sempre a serviço dos patrões. Como se em casa também não houvesse relações de dominação e de poder que subjugam e desrespeitam. O próprio fato de os irmãos não fazerem nada enquanto as meninas cuidam do serviço doméstico é significativo. No entanto, elas parecem não compreender a condição de vítimas na própria casa. Apenas na casa dos outros. 
Entre as adolescentes do "centro de formação", realizar serviços domésticos na própria casa é considerado um dever:

Moderadora: E na casa de vocês. Vocês consideram trabalho o que vocês fazem? Todas juntas: Não!

Tatá: Eu acho que é uma obrigação.

Nati: Porque, assim [...] Tem que ver por esse lado. [...] É o nosso lado também. Saber que nossa mãe anteriormente trabalhou pra caramba para ajudar nosso futuro. [...] A gente tem que ajudar ela. (CENTRO DE FORMAÇÃO)

Nesse sentido, o trabalho doméstico em casa é uma forma de a adolescente compensar os esforços da mãe, de retribuir o trabalho que as mães tiveram com a família. Entretanto, as adolescentes ouvidas, tanto no grupo "projeto social" quanto no do "centro de formação", destacaram também tensões e problemas que vivenciam no trabalho na própria casa, um dos principais está o fato de as famílias, por vezes, exigirem que só as meninas cuidem das obrigações domésticas.

Cris: Eu acho que todo mundo tem que fazer as coisas. Não é só a mulher.

Lecka: $\mathrm{E}$ eu também acho que tem gente que acha.. Homens, não é? Uns, não são todos que pensam assim! Que é obrigação da mulher: 'é a mulher que tem que fazer e não nós, nós não temos que fazer nada. Não é a nossa obrigação. Elas que tem que lavar, passar, cozinhar, fazer tudo'.

Michelle: Isso é verdade, porque a maioria dos meninos lá em casa falam: 'Ah, isso é você que tem que fazer, porque isso é dever da mulher e não do homem'. Ele fala para você vê!

Moderadora: $\mathrm{E}$ tu falas alguma coisa para ele?

Michelle: Eu falava: Ah é, sim. Primeiro tu tem que arrumar uma mulher pra ti, pra ela fazer pra ti, porque eu não sou a tua empregada.

Moderadora: E ele?

Michelle: Aí ele fala: 'é porque tu é muito retardada' (risos).

Moderadora: Ele fala isso?

Lecka: Não também porque se a gente, se o homem não tiver uma mulher que lave roupa, lave as suas coisas, pegue as suas coisas e deixe tudo ajeitadinho. Ele realmente não é nada. Tem uns. Tem alguns que são assim, meio asseados, mas tem uns que ainda são muito porquinhos.

Moderadora: Então os homens não sabem cuidar da casa? 
Cris: Não.

Lecka: Às vezes.

Alicinha: Na maioria das vezes eles só sabem bagunçar.

Lecka: Pois é, ela [a mamãe] pensa dessa forma. Ela disse que quando ele arrumar uma mulher, ele pode ficar olhando. Mas enquanto ele estiver lá em casa, ele vai ter que fazer as coisas.

\section{Moderadora: Ah tá!}

Alicinha: A tua mãe já diz assim, já quer que ele faça. E lá em casa a mamãe não quer que o Breno faça nada, que é só a gente. Aí ele só vive na rua empinando pipa e a gente que fica dentro de casa fazendo as coisas.

Michelle: Na maioria das vezes o nosso pai ainda chama a gente de preguiçosa: 'é porque você só quer ficar namorando, só quer ficar na rua'. Esse final de semana eu saí com meu namorado, aí eu cheguei lá em casa na segunda feira, aí ele ficou xingando a gente: 'porque você tá muito preguiçosa, tá muito vadia'. Aí a mamãe fala: 'Certo! Tu quer bem que a menina fique trabalhando de segunda a segunda. Ela não é escrava não, tem mais que passear mesmo, aproveitar'. É assim que a minha mãe falou. (PROJETO SOCIAL, grifo nosso)

A lógica opressiva de gênero que incumbe à mulher as tarefas domésticas opera entre as próprias adolescentes. Embora elas afirmem que os homens precisariam ajudar e que não seria somente uma obrigação feminina, elas reforçam em vários momentos o discurso opressor. É o que Michelle faz, por exemplo, quando solicita ajuda do irmão. Ela diz que ele precisa cuidar da casa porque ainda não tem uma mulher que faça isso para ele. Como resposta, o irmão a ofende, chamando-a de retardada. O discurso da inferioridade da mulher é materializado pela ofensa do irmão que se recusa a realizar tarefas domésticas e afirma que a irmã está louca ao solicitar que ele divida as responsabilidades.

O reforço ao discurso do doméstico como lugar feminino é feito também pela Lecka. Ela afirma que o homem precisa de uma mulher que faça "as coisas" para ele, já que, segundo ela, ele não sabe fazer direito ("Tem alguns que são assim meio asseados, mas tem uns que ainda são muito porquinhos”). O que é corroborado pela Alicinha, segundo quem os homens só bagunçam.

Outro modo de power over dado a ver pelas adolescentes é a sujeição ao poder paterno, do "chefe de família", o que remonta à dominação patriarcal. (WEBER, 1991b) A adolescente Michelle conta que o pai faz xingamentos e a ofende quando ela não cumpre as obrigações domésticas. Ele diz que ela está preguiçosa, 
chama-a "vadia", porque quer namorar ao invés de cuidar da casa. Quem a defende é a mãe, ao afirmar que a menina não é escrava e que tem o direito de aproveitar a vida. Nota-se que a própria adolescente não relata responder ao pai. Talvez não o faça em razão do medo de ser ofendida ou por achar que não tem poder de questionar a postura dele. Ao mesmo tempo, a menina demonstra um modo de fuga, de resistência, quando some de casa e passa o final de semana com o namorado.

Como estamos vendo, o trabalho, mesmo na própria casa das adolescentes, apresenta tensões e problemas. Em todos os grupos que analisamos, a grande maioria das entrevistadas desenvolvia obrigações domésticas tanto na própria casa quanto na casa de terceiros. Entre as adolescentes do "centro de formação", algumas não atuavam em casas de família, mas tinham uma longa jornada de trabalho na residência dos próprios pais, e, mesmo não gostando de algumas atividades, consideravam, conforme apresentamos anteriormente, como uma obrigação da menina perante, sobretudo, a mãe.

Lorrane: O que eu mais não gosto é de varrer a casa. O resto eu faço tudinho.

Drika: Eu também não gosto, não.

Tatá: Também não.

Moderadora: $\mathrm{E}$ tu, Ana?

Ana: Eu não gosto de lavar louça. Só tem uma coisa que eu não gosto. Eu não gosto de lavar louça.

Moderadora: Mas vocês fazem as coisas todo dia?

Tatá: Todo dia.

Nati: Todo dia arrumo a casa.

Moderadora: E tem alguém que ajuda vocês?

Tatá: Não.

Nati: Não.

Tatá: Lá em casa [...] só é eu e a vovó. E ela não faz.

Moderadora: E me digam uma coisa, o que vocês acham de trabalhar em casa, de fazer esse serviço que vocês fazem?

Drika: [Risos] Às vezes dá preguiça.

Nati: Não posso nem dizer se é bom ou se é ruim [...]. Faço, mas eu não gosto de fazer. (CENTRO DE FORMAÇÃO) 
A discussão no grupo revela relações de power over como formas de dominação tácita. Na fala das participantes, não há expressão do entendimento de que as tarefas que realizam em casa se configuram como trabalho de fato, seja pela frequência, seja pela extensão. Essa ausência faz com elas não se considerem trabalhadoras domésticas, mas apenas boas filhas, porque o âmbito em que realizam esse serviço é o da própria família. Há, ainda, um forte componente moral do dever de reciprocidade para com a mãe, que se dedicou para criá-las, como visto anteriormente.

Tensões entre as perspectivas dos media e das afetadas acerca das definições do TID

De acordo com a perspectiva que os jornais construíram sobre essa primeira temática, evidenciamos alguns elementos principais. O TID foi definido como uma atividade na qual prepondera uma relação de dominação (power over) que subsiste, principalmente de maneira latente, o que suaviza processos de dominação e faz com que não sejam percebidos por suas maiores vítimas. Assim, os jornais atuaram no sentido de desvelar componentes ideológicos que sustentariam o TID, destacando como falsas as promessas que incentivam a saída de crianças para casas de família.

Nesse sentido, o lugar de fala atribuído a meninas trabalhadoras e ex-trabalhadoras domésticas é o de quem, num primeiro momento, não percebe, no próprio discurso, sempre ponderado ou questionado pelos jornais (com o uso de aspas, por exemplo, ou com a intervenção direta da jornalista para "esclarecer" a "realidade" do TID à trabalhadora), os pressupostos da dominação. Nesse último caso, por meio da apresentação da personagem à conceituação do TID sob a perspectiva dos agentes de advocacy, há certa reviravolta no modo como o jornal a posiciona naquela teia narrativa: de vítima orgulhosa, que se sente estimada pelo fato de o patrão gostar do seus bolos ou por achar que faz parte da família, à vítima resistente, com capacidade de crítica ao TID e que questiona a responsabilidade dos governos nesse problema.

Assim, os significados atribuídos ao trabalho infantil são relacionados à violação de direitos, à exploração de meninas e à escravidão. Na cena construída em torno do TID, não há referência a conflitos. Como os processos de dominação são considerados internalizados, o que ganha relevância são os processos de re- 
signação e aceitação do TID. Nesse sentido, parece não haver resistência, e a sujeição da menina trabalhadora é a regra. Contudo, há uma quebra nesse cenário por meio da introdução das ações de organizações sociais pelo enfrentamento ao TID, sobretudo, o Cedeca-Emaús, por meio do Petid. Quando meninas atendidas pelo Programa ganham espaço nos jornais, constrói-se um discurso acerca da resistência delas ao TID com a ajuda decisiva do Petid. Por essa razão, expressões como "A vida delas mudou quando conheceram o Centro de Defesa da Criança e do Adolescente (Cedeca)" destacam essa lógica discursiva. Foi abordada ainda, a participação dessas adolescentes na atuação política contra o TID, mas seguindo o mesmo tipo de construção discursiva, a partir da qual essa atuação só foi possível por meio do Petid.

Nos grupos focais, o cenário em torno da conceituação do TID ganhou nuances distintas, e os conflitos foram evidenciados. Um dos elementos apontados pelos jornais (e pelos especialistas) é que pensar ser um membro da família seria um indicador do processo tácito de dominação. Nas discussões entre as afetadas, esse ponto foi bastante questionado, e praticamente todas reforçaram que esse era um discurso utilizado pelas famílias "da casa para fora”, mas que a realidade era outra: por exemplo, tipos diferentes de escola para os filhos consanguíneos e a "filha adotiva", ou ainda a comemoração do Natal com a família na sala e a menina trabalhadora na cozinha.

Mesmo uma das participantes (Tamires) tendo feito a defesa e fornecido explicações para justificar o porquê se considerava alguém da família da patroa, ela mesma informou que "claro" que os filhos da patroa iam para escola particular enquanto ela frequentava o ensino público. Mesmo as adolescentes ouvidas se referem com clareza sobre o que as faz trabalhadoras e não membros da família no exercício do TID. Assim, nem mesmo os laços consanguíneos seriam suficientes para que elas se reconheçam como membro da família, como no caso de Erizinha, que trabalhava para a avó. Entretanto, quando se referem aos pais, principalmente à mãe, a ideia de trabalho assume a conotação de uma obrigação.

Sobre o entendimento do TID como escravizante, apesar de a maioria concordar com essa perspectiva, houve discordância em relação ao que fazia do TID uma relação de trabalho escravo. Algumas, como as mulheres do "sindicato", por exemplo, entendiam que o TID como um todo remeteria à escravidão, outras destacaram que alguns elementos poderiam ser indicativos dessa condição, como a exigência por meninas domésticas que durmam no emprego, ou ainda 
quando se descumprem as promessas acerca de quais tarefas elas assumiriam, ou também quando a patroa limitava a quantidade de comida.

As defesas e também os argumentos discordantes desses posicionamentos revelaram um complexo jogo entre relações de poder, nas quais power over e power to se manifestam de modos diversos e ambíguos. Morar na casa da família, por exemplo, foi considerado tanto uma forma de dominação, porque impõe que a doméstica fique o tempo todo à disposição dos patrões, quanto um modo de não gastar tempo demais com longos deslocamentos, ou, quando adolescente, de ser cuidada. Sobre a oferta de comida, por exemplo, ao mesmo tempo em que Nanã se coloca como vítima das severas restrições alimentares impostas pela patroa, a dependência que possui em relação à tia que a inseriu no TID recoloca-a dentro de uma relação de power over, na medida em que constitui-se um laço moral de obrigações dela em relação àquela, e também pela tia fazer as escolhas de onde ela trabalharia. Entretanto, essa mesma relação com a tia era o que garantia que ela recebesse um salário mínimo desde os treze anos e também era um porto seguro ao qual poderia recorrer se corresse perigo ou passasse dificuldade.

Outras discussões que iluminaram essa articulação imbricada entre o posicionamento como "vítimas" ou como "resistentes” foram as distinções entre babá e doméstica e também a tensão entre a doação de objetos como generosidade da patroa ou como uma estratégia para manter a relação de dominação. Sobre a diferença entre trabalhar como doméstica ou como babá, as adolescentes do "centro de formação" apontaram que ser babá permite a construção de um relacionamento diferenciado com a família empregadora porque a dependência da criança vai fazer com que os pais precisem muito da babá, de tal modo que fazer com que a criança se apegue é uma forma de resistência a condições de exploração no TID. O modo como as sindicalizadas discutiram a doação de objetos pela patroa evidenciou a crítica a essa ação como uma estratégia de manutenção da dominação, que estimularia a lealdade e a submissão da doméstica à patroa, ou ainda como uma forma de utilizar esse gesto a favor da empregada como modo de resistência a condições de vida adversas.

O modo como o jornal tratou a temática do trabalho na própria casa revelou um pano de fundo de incertezas, ambiguidades e imprecisões, reverberando, dessa forma, a dificuldade das próprias organizações sociais em precisar os limites do TID, quando ele ocorre no seio familiar. Ainda que fortuitas, as matérias sobre o acidente com o cão ou ainda sobre a Comunidade do Aurá expuseram a 
vulnerabilidade à qual crianças e adolescentes em situação de trabalho em casa estão sujeitas, por vezes, vitimizadas pelos próprios pais. Contudo, o discurso do jornal também endossa esse posicionamento e implicitamente corrobora, em alguns momentos, com lógicas que sustentam práticas opressivas, quando, por exemplo, reforça o lugar da menina Linda Inês como "mulher da casa”.

De modo complementar, há contradições entre resultados de pesquisa apresentados e o uso de uma personagem. Enquanto na discussão sobre os dados estatísticos transparece o entendimento do TID em casa como uma forma de dominação, o relato da história da personagem atribui vantagens ao trabalho das filhas em casa como maneira de adquirirem habilidades para "poderem se virar sozinhas". Quando é destinado espaço de fala às adolescentes como "resistentes", o objeto da resistência é o trabalho na casa de terceiros, e não na própria casa.

Nos grupos focais, "trabalhar em casa" adquiriu significados distintos dependendo das experiências de vida das meninas e mulheres entrevistadas. Para as que vieram de municípios do interior, por exemplo, trabalhar em casa quer dizer "trabalhar na roça", o que é visto pela maioria delas como penoso demais. Wanderléia citou um modo de resistência a esse tipo de trabalho, como "fazer corpo mole", ou seja, descansar escorada na enxada, o que era violentamente reprimido pela mãe e fez com que ela se sentisse "coberta de ouro" quando passou a trabalhar de babá na casa de um prefeito.

Para as adolescentes do "projeto social”, trabalhar em casa é melhor do que na "casa dos outros", porém faz com estejam sujeitas à dominação da própria família. Essa relação de power over se configura por meio da internalização e do compartilhamento na família de uma lógica opressiva de gênero que demarca o espaço doméstico como responsabilidade feminina. Apesar das críticas que as meninas lançam a essa perspectiva, elas, em alguma medida, também aderem a esse discurso quando afirmam que o homem não sabe cuidar da casa e que precisa encontrar uma mulher para ele. Mesmo nesse contexto, elas encontram modos de resistir a essa forma de dominação, como "fugir" dos serviços para namorar.

Para as adolescentes do "centro de formação", as atividades domésticas pelos quais são responsáveis em suas casas não são uma forma de trabalho, e sim uma obrigação. Por essa razão, elas não expressaram modos de resistência porque aquele dever moral era um pressuposto internalizado frente ao qual não cabia contestação. 
Por meio da discussão dessa primeira temática nos grupos focais, foi possível perceber que o quadro das relações de poder em torno o que é esse tipo de trabalho infantil é marcado por ambivalências, e o posicionamento das meninas e mulheres nessa teia de poder se situa para além da vitimização e do completo assujeitamento, que implicaria o não reconhecimento da situação em que vivem e dos lugares que lhes são atribuídos. Entretanto, quando o assunto em questão é o trabalho na própria casa, o questionamento dessa prática se torna mais problemático.

\section{VIVÊNCIAS NO TID: VIOLÊNCIA E EDUCAÇÃO}

Além das tensões em torno da definição do TID que destacamos na seção anterior, consideramos pertinente analisar também o que a tematização e a discussão de experiências ligadas à violência e à educação revelam sobre as relações de poder nesse tipo de trabalho. Ambos os temas são frequentemente considerados como os principais prejuízos do TID, relacionados à vulnerabilidade da criança ou adolescente a situações de violência e ao fracasso na escola, ocasionado por longas jornadas de trabalho em detrimento do direito de aprender. (INTERNATIONAL LABOUR ORGANIZATION, 2004, 2013; LAMARÃO, 2008; LAMARÃO; MENEZES; FERREIRA, 2000) Como os media abordaram esses assuntos? Como as afetadas foram posicionadas nas discussões sobre violência e educação? Como elas construíram sentidos em torno dessas temáticas e o que isso revela das relações de poder? Em primeiro lugar, abordaremos a discussão sobre violência para, em segundo, tratar da educação.

\section{Violência}

A cobertura dos jornais da violência relacionada ao TID manteve o foco, principalmente, em notícias factuais sobre estupro ou torturas envolvendo meninas que trabalhavam em casas de terceiros. No levantamento, apareceram poucas matérias analíticas acerca da violência que ocorre ou pode ocorrer com trabalhadoras infantis domésticas. Consideramos a referência a essa temática quando as matérias faziam menção a violências explícitas no TID, o que resultou em um total de 18 matérias (8,7\% do material jornalístico analisado). Como ocorre com o 
assunto "violência contra crianças e adolescentes" de maneira geral nos jornais impressos (ANTUNES; LARA, 2013), a violência no TID também foi abordada de modo aleatório e com raríssimas articulações com a discussão mais ampla sobre o TID que vinha ocorrendo a partir do estímulo de organizações sociais.

As vozes de meninas trabalhadoras domésticas vítimas de violência são também pontuais e aleatórias, mas são inscritas sob a forma do testemunho e buscam chamar atenção para a violência sofrida. Em uma notícia publicada em 15 de agosto de 2001, em O Liberal, C., de 14 anos, expressa a dor que sentia por ter sido dada pela mãe a uma pessoa, o que a deixou vulnerável a viver situações de violência:

C. disse que foi entregue à Fabrícia [patroa], que nem disse o endereço para onde seria levada.'Fui dada como se dá um cachorro', disse C. [...] C. contou que, na casa de Fabrícia, fazia todo o serviço doméstico, como limpar a casa, lavar louças, fazer almoço e o jantar. E ainda lavava grandes trouxas de roupas, de toda a família. [...] Fabrícia batia com a cabeça dela [C.] na parede e, em seguida, apanhou uma colher em brasa e avisou: Se tu fugires, mais tarde vou te matar. Depois obrigou C. a abrir a boca e lhe queimou a língua com uma moeda em brasa. Também queimou-a (sic) pelo corpo 'para tu não me esqueceres nunca mais'. (O LIBERAL, 15/08/2001)

De acordo com a matéria, foi uma vizinha que levou C. à casa de uma conselheira tutelar que denunciou o casal à polícia. A narrativa construída detalha uma das situações sofridas por C. naquela família e o ressentimento com a mãe. O lugar de fala atribuído à adolescente é o de vítima, tanto do descaso da mãe quanto dos maus-tratos da patroa. A crueldade do gesto de violência também é reforçada pelo modo como o possível discurso da patroa para a adolescente é reconstituído pelo jornal (“Se tu fugires, mais tarde vou te matar”, ou ainda "para tu não me esqueceres nunca mais”). A fala da adolescente exprime a dor moral de ter sido rejeitada pela mãe. Assim, ela experimentou duplamente a recusa ao reconhecimento básico em suas relações primárias (em relação à mãe e a patroa). Experiências de desrespeito dessa natureza, de acordo com Honneth (2003) representam uma injustiça não apenas porque ocasionam danos aos sujeitos, mas também por provocarem uma profunda humilhação que destrói a 
compreensão positiva de si mesmas, adquirida intersubjetivamente. Além disso, os maus-tratos físicos como os que ela sofreu corroem a autoconfiança básica dos sujeitos, que são feridos na possibilidade de livre disposição de seus corpos. (HONNETH, 2003) Nesse contexto, a relação de poder que o texto desvela é a de power over, cuja coerção é baseada na violência e no consequente rebaixamento moral da menina, que é vítima.

Faleiros destaca que atos de violência praticados contra crianças e adolescentes por adultos são formas de encarnação de relações de dominação:

\footnotetext{
Esta violência manifesta, concretamente, uma relação de poder que se exerce pelo adulto ou mesmo não adulto, porém mais forte, sobre a criança e o adolescente num processo de apropriação e dominação não só do destino, do discernimento e da decisão livre destes, mas de sua pessoa enquanto outro. (FALEIROS, 1998, p. 10)
}

Essa forma de poder se manifestou ainda quando a mãe a descartou, "como se dá um cachorro", e no modo como a patroa se apropriou dela, como um objeto entregue à dependência e à sujeição ao adulto. A violência se manifesta, assim, de forma muito peculiar: não apenas sob a forma de restrição de ações, mas do controle do corpo, da imposição de disciplina pelo uso da força. Trata-se da forma mais brusca, mas também mais explícita da dominação. Usa-se a violência para mostrar poder sobre o outro. No caso da adolescente C., esse ponto se evidencia. Por outro lado, a menina não é só vítima do TID, como nos outros casos. Ela é um sujeito vulnerável pela idade, pela compleição, pela situação. Nessa situação, é necessário pensar na vitimização provocada pelo TID e construída narrativamente pelo jornal, mas também na condição plena de vítima da adolescente, que extrapola a situação de trabalho e se espraia por toda a sua trajetória. Apesar dessa condição dramática, o relato do jornal restringe-se à denúncia da violência cometida pela patroa e não apresenta questionamentos mais amplos sobre o TID, ou ainda, sobre as possibilidades para crianças e adolescentes com histórico semelhante de vitimização.

A submissão das meninas domésticas ao poder de mando dos patrões, que pode abrir caminho para a violência sexual na casa em que elas trabalham, foi tematizada nos jornais. Em uma matéria veiculada no Diário do Pará, em 13 de abril de 2004, uma promotora de justiça lança uma iniciativa para cadastro no 
Conselho Tutelar de meninas que estavam trabalhando como domésticas em casa de família de Oriximiná, município do interior do estado, como forma de prevenir a violência sexual:

Diante do alto número de abusos sexuais, a promotora Ângela Maria resolveu promover uma campanha junto às famílias que possuem adolescentes sob sua responsabilidade trabalhando como domésticas. [...]

'Não iremos entrar no mérito do emprego salarial, mas temos que resguardar que se evite abuso por parte do patrão e da patroa. Tudo bem que trabalhe, mas que trate com dignidade e não com excesso. Muitas vezes, por não haver fiscalização, as pessoas acabam consumindo demais a adolescente, então, a partir do momento que ela (pessoa responsável) vê a presença do Conselho (Tutelar), ela passa a partir daí a ter uma responsabilidade maior e melhor com a adolescente, principalmente, tratando-a com dignidade', explica Ângela Maria.

'Nunca tinha visto tanta incidência de estupro entre famílias, como existe aqui neste município. Já passei em outros municípios e a incidência não chega a esse número absurdo, é impressionante como a proporção é grande, nem em cidades como Santarém, que já é considerada como uma metrópole em relação à Oriximiná, não tem esse número', lamenta promotora de justiça, impressionada com a situação. (DIÁRIO DO PARÁ, 13/04/2004, grifo nosso)

Não há, portanto, uma crítica ao TID propriamente, mas menção a medidas para evitar a vulnerabilidade à violência sexual que esse propicia. O discurso acerca da dignidade no TID residiria no fato de as meninas serem bem tratadas e, para tanto, seria necessário haver fiscalização (“Tudo bem que trabalhe, mas que trate com dignidade e não com excesso”).

Em uma das poucas matérias mais críticas acerca da relação entre TID e violência, são destacadas as dores física e moral vivenciadas por meninas domésticas.

Um dos maiores dramas do trabalho infantil doméstico é que ele deixa marcas que a sociedade não enxerga, mas que são profundas e carregadas durante anos pelas meninas que um dia passaram por 
isso. Muitas delas relatam com uma triste naturalidade passagens em que foram ameaçadas ou maltratadas por patroas e não raramente se mostram resignadas com a situação de extremo desrespeito e violência. 'Uma vez, ela (a patroa) ameaçou me jogar embaixo de um carro seu não cuidasse direito do filho dela', disse Marlene do Socorro Teixeira da Silva, hoje com 18 anos.

[...]

A mãe [de Marlene], dona Argentina, já falecida, engravidou do filho do patrão - situação muito comum, já que não são raros casos em que filhos e maridos de patroas se aproveitam sexualmente de adolescentes. (O LIBERAL, 10/05/2007)

Marlene tinha 14 anos quando começou a trabalhar nessa casa. O lugar de fala imposto a ela pelo discurso jornalístico é marcado por expressões relacionadas à aceitação da dominação, como a indicação de que as situações de violência são relatadas com "uma triste naturalidade" e a partir de uma postura de resignação, de tal modo que a ameaça ou a violência são entendidas como características (ou riscos corriqueiros) do TID. Não há menção a possibilidades de crítica ou questionamento dessa realidade pela própria personagem vitimizada pelo TID. O texto mobiliza um entendimento do TID como baseado em uma relação de poder que chega ao limite da violência contra o outro, das ameaças, e que é tratada com naturalidade de tão comuns que são. Nesse contexto, parece não haver alternativa senão a total sujeição aos mandos e desmandos dos patrões. O componente da resistência (ALLEN, 2000; FOUCAULT, 1995) e do desrespeito como motivação para a luta (HONNETH, 2003) não são considerados ou mencionados. Assim, o direcionamento da matéria enclausura a personagem no papel de vítima, e o modo como faz isso impossibilita o vislumbre de uma transformação nesse cenário ou na posição que a adolescente trabalhadora doméstica ocupa no mundo (subject-position).

Em um único texto sobre a violência no TID, há o posicionamento discursivo de uma adolescente como vítima resistente. Esse ponto é ressaltado desde o títu1o "Depois de torturada, menina de 12 anos sonha em ser delegada":

Depois de uma denúncia anônima, a polícia prendeu uma empresária acusada de torturar uma menina de 12 anos, que morava na casa dela. A polícia diz que encontrou a vítima acorrentada e amordaça- 
da na cobertura de um prédio de Goiânia. Ontem, a garota afirma que sua vida mudou. A menina vive em um abrigo, até que o juiz da Infância e da Juventude, Maurício Porfírio, decida com quem ela vai morar definitivamente. Ela virou um exemplo da luta contra a violência infantil e aprendeu que, como criança, também tem seus direitos previstos em lei. A menina diz que está feliz e faz planos para o futuro. Ela conta que quer estudar para ser delegada. 'Aquela menina que sofreu, agora é uma menina que está indo para frente.'

[...] Quinta-feira, 10, Silvia e outros acusados de envolvimento no caso foram ouvidos pela Justiça. De acordo com a assessoria do Tribunal de Justiça, ao juiz, ela disse que era bastante 'enérgica' com a menina de 12 anos e acreditava que estava educando e não torturando. O TJ informou ainda que a empregada da empresária, Vanice Maria Novaes, negou a prática dos crimes e que sabia das agressões de Silvia contra a menina. Ela disse que a empresária controlava a alimentação da menina, de modo que 'se tomasse café, não almoçava; se almoçasse, não jantava'. A doméstica admitiu ter segurado as pernas da menina enquanto a empresária a sufocava com um saco plástico. Ela justificou sua atitude dizendo que Silvia lhe fazia ameaças de morte. (O LIBERAL, 18/04/2008)

A “educação” imposta pela patroa à adolescente lembra, em muitos aspectos, o processo educativo utilizado na criação de crianças cativas no Brasil nos séculos XVIII e XIX: “O adestramento da criança também se fazia pelo suplício. Não o espetaculoso, das punições exemplares (reservado aos pais), mas o suplício do dia a dia, feito de pequenas humilhações e grandes agravos”. (GOÉS; FLORENTINO, 2007, p. 185-186) No exemplo contemporâneo, a "disciplinarização" da doméstica adolescente era encarada com um dever pela patroa, que, pela coação e ameaça, fazia da doméstica adulta sua cúmplice. O uso de aspas na palavra "enérgica" agrega uma crítica ao discurso de defesa proferido pela patroa. Em relação ao lugar de fala da menina trabalhadora, apesar de bastante marcado pelo detalhamento do processo de vitimização, situa-a num espaço de alguma resistência, já que, embora tenha sofrido violência, construiu um projeto de vida e está disposta a persegui-lo, o que, por sua vez, foi oportunizado pelo fato de estar sendo assistida pelo Estado. 
Conforme apresentamos no quarto capítulo, consideramos o TID um tema sensível para a realização de grupos focais, já que poderia estimular a recordação de momentos de sofrimento. A discussão acerca da violência parecia-nos a mais delicada de todas. Apesar da tentativa de fazer com que as meninas e mulheres entrevistadas se sentissem à vontade nos grupos para manifestarem suas opiniões e relatarem suas vivências, surpreendeu-nos que elas considerassem aquele momento propício para expor detalhadamente graves violências sofridas quando eram trabalhadoras infantis domésticas. Algumas afirmaram nunca terem contado sobre aquelas experiências antes.

Mesmo tratando de assuntos graves, aqueles relatos não culminaram em lágrimas. Havia no olhar e no posicionamento daquelas mulheres que viveram abusos e tentativas de abuso nos lares em que trabalhavam não somente a dor pelo passado, mas um forte desejo de manifestar e compartilhar o que passaram como forma de questionar o contexto que havia levado a isso. Fazer uso da palavra para manifestar algo tão íntimo e doloroso era quase como buscar justiça, demonstrar a indignação por, mesmo sendo adolescentes, terem que passar por aquelas violências.

De modo geral, das discussões sobre violência e TID nos grupos analisados, emergiram alguns pontos principais: a) o (des)respeito à empregada adolescente, b) as ameaças e o medo de falar o que acontecia, c) relatos de abusos sexuais ou de tentativas, d) a inferioridade da trabalhadora doméstica frente aos patrões.

No grupo das adolescentes do "centro de formação", por exemplo, elas afirmaram de modo taxativo que as meninas não são respeitadas pelas patroas:

Moderadora: Como é normalmente o relacionamento da patroa com a empregada?

Lorrane: Na base da ameaça.

Ana: A da minha mãe, não. A da minha mãe respeita.

Moderadora: E como é que é quando a empregada é adolescente?

Tatá: É muito raro [encontrar respeito]. É quase uma vez na vida outra na morte. Moderadora: Mas por que vocês acham que é diferente quando a empregada é adolescente e quando a empregada é adulta?

Tatá: É porque é assim. A empregada adolescente, a patroa não tem muito respeito com a empregada adolescente. Já com a adulta, ela tem mais respeito, por 
causa que a adolescente não pode fazer nada, agora a adulta pode. Pode te jogar na justiça por causa de ameaça. [...]

Nati: Acho que ela respeita a adulta, com certeza. A adolescente, ela não sabe fazer tudo sozinha. (CENTRO DE FORMAÇÃO)

A falta de autonomia das adolescentes, segundo as entrevistadas, estimula que os patrões achem que podem desrespeitar a doméstica sem consequências, o que seria distinto de uma mulher adulta que poderia buscar na justiça os seus direitos. Por que, para elas, a menina não pode agir dessa forma? Em razão do processo de dominação e cerceamento do adulto (patroas) sobre a criança ou adolescente (FALEIROS, 1998), que faz com que as últimas não possam (ou não tenham meios para) questionar as primeiras. As próprias adolescentes ouvidas reforçam, assim, um lugar vitimizado da menina doméstica, quando subjugam sua capacidade de ação ("ela não saber fazer tudo sozinha”).

As entrevistadas do "projeto social" recolocam essa situação de modo relativamente distinto: para elas, muitas meninas não falam, não relatam casos de violência e/ou maus-tratos por terem medo de represálias.

Michelle: Muitas vezes os patrões querem abusar das empregadas. Querem ter relação: 'ah, porque tu trabalhas para mim vai ter que fazer o que eu quero'.

Lecka: Eles têm que entender que a gente trabalha e não que é um objeto sexual deles. É assim que eles têm que ver.

Moderadora: O que vocês acham? É certo ou errado?

Todas respondem ao mesmo tempo: É errado.

Moderadora: Então vocês acham que trabalhar não dá o direito de fazer qualquer coisa?

Michelle: Com certeza. Trabalho é trabalho. E... 'Ah! Tu vai trabalhar na minha casa, tu vai fazer o que eu quero'. Eu não estou trabalhando para ter relação com o marido dela. Eu sou virgem! E não dá o direito de ter relação com o marido dela. Não sou objeto. Fui contratada para trabalhar na casa dela e não para deitar com o marido dela na cama dela, não é verdade? É a minha opinião.

Moderadora: Aí a patroa também deve ficar bastante irritada...

Participantes: Com certeza.

Alicinha: Tem patroa que até quer encobrir para não perder o marido, para o marido não ser preso e para não acontecer aquele vexame. 
Michelle: Na maioria das vezes a mulher que encobre o marido é porque ele ameaça ela, bate nela. É porque na maioria das vezes ela se sente na obrigação de encobrir o marido dela. (PROJETO SOCIAL, grifo nosso)

O projeto social no qual essas adolescentes entrevistadas estavam envolvidas era um de apoio a meninas vítimas de violência sexual. Quando propomos a realização do grupo focal, a educadora que acompanhava o grupo combinou que elas não precisariam falar do "segredo" que tinham em comum. ${ }^{12} \mathrm{~A}$ partir disso, esse assunto não foi diretamente incentivado por meio do roteiro do grupo focal, mas surgiu naturalmente durante aquele processo interativo, trazido à tona pela adolescente Michelle.

A discussão deu a ver duas distintas nuances das relações de power over envolvidas no contexto de violência no TID. Em primeiro lugar, questionaram a ideia, que remonta ao período escravista, de que a menina doméstica estaria à disposição também para satisfazer os desejos sexuais dos patrões. Esse tipo de abuso revela a fragilidade da posição da menina trabalhadora doméstica em comparação ao lugar do patrão (ou do filho dele). Trata-se de um modo de exercício de poder explícito no qual há pressão para que o sujeito em condição vulnerável contemple os interesses dos mais poderosos, ainda que eles estejam em conflito com os seus próprios interesses. (DAHL, 1957; LUKES, 1980; PERISSIONTO, 2008)

Em segundo lugar, revelam outro nível de dominação que participa do contexto em que a violência sexual contra meninas trabalhadoras é exercida: a dominação do marido em relação à esposa. Nesse contexto, a proposição de Allen $(1998,2000)$ sobre uma visão multifacetada do poder contribui para lançar luz aos arranjos de poder que estão em jogo nesse caso. Se, em relação ao marido, a patroa encontra-se numa situação de dominação, em relação à doméstica ela se encontra empoderada. Em razão disso, ela se posiciona ao lado do marido: ou não acredita na adolescente ou encobre a violência cometida pelo marido para não correr o risco de perdê-lo. As adolescentes contestam enfaticamente essas situações, questionando uma face perversa do power over envolvido no TID.

\footnotetext{
12 Como respeitamos esse acerto inicial, não indagamos se a violência sexual havia sido cometida no contexto do TID ou em outro. Apenas ouvimos o que elas estavam comentando sobre esse assunto, sem instigar para saber se já tinham passado por isso e em quais circunstâncias.
} 
Quando precisam superar essas situações de abuso, algumas trabalhadoras infantis domésticas enfrentam dificuldade de conseguir apoio na própria família. Foi o caso de Duda, do grupo Cidade de Emaús:

Moderadora: E vocês? Vocês tiveram experiência de trabalho em casa de família ou de babá? Ou na sua própria casa quando eram crianças ou adolescentes?

Duda: [...] Eu acredito que com treze, quatorze anos, eu já fui colocada em casa de família. [...] Mas eu também não gostava muito, não. Eu ficava mais lá por causa do meu pai, porque ele era um pouco rígido. Não é? E a minha mãe tinha que seguir o que ele queria, não é? Porque se ela fizesse ao contrário, ele ficava aborrecido com ela, não é? Então, às vezes eu ia passar final de semana na casa dos meus pais, aí eu falava para eles. Às vezes eu falava para eles que eu não queria voltar para aquela casa lá, não é? E eu falava geralmente para a minha mãe, não é? Porque eu tinha mais intimidade, aí ela dizia: 'não, minha filha, você tem que ficar lá porque se você vier embora para cá o teu pai vai brigar'. Quer dizer, ela não procurava saber o porquê que eu não queria ficar lá, não é? Por que eu não estava gostando? Ela preferia seguir o que o meu pai queria, não é? Ela se preocupava mais com ele do que comigo, então isso aí eu tenho um pouco de ressentimento por causa disso. Porque é por isso que acontecem muitas coisas hoje, porque às vezes a criança quer lhe contar alguma coisa e a pessoa, o adulto não escuta, não é? Ele não presta atenção no que a criança quer falar. Então eu já vivi isso. Porque até uma época eu fui morar em uma casa, essa família eles eram de lá do nosso lugar, não é? E minha mãe tinha muito respeito pala mãe da moça, pela família da moça, não é? Pelos pais da moça que morava aqui, ela já era casada, tinha filhos. Aí eles me jogaram lá nessa casa, não é? Aí, quando eu ia passar final de semana, que eu ia uma vez por mês para casa da minha mãe, aí uma vez eu falei para ela que eu não queria mais voltar pra lá porque eu não estava me sentindo bem e ela não procurou saber por que, não é? Mas o que acontecia lá na casa, eu dormia em uma rede em um corredorzinho e eles tinham o quarto deles, tinham uma mercearia lá, não é? E eu fazia de tudo na casa, lá tinha criança e eu cuidava. E, à noite, o homem ia passar a mão em mim.

Heloísa: Que safado!

Duda: O marido da mulher, ele saía do quarto dele, inventava que ia ao banheiro e ele passava bem pertinho da minha rede e eu não dormia. Eu não conseguia dormir, porque parecia que eu ficava só esperando, porque eu sabia que ele ia. Só que eu tinha medo de falar para a mulher. Aí um dia eu cheguei a falar para a minha mãe e ela disse que aquilo era bobagem minha, entendeu? E o homem ia passar 
a mão em mim. Eu tinha que vestir short, eu tinha que vestir um bocado de roupa porque eu tinha medo dele me apalpar, assim, chegar mesmo, não é? Porque ele abria a rede e ficava puxando o lençol querendo me apalpar na minha rede. Então eu vivi essa experiência assim e quando eu me lembro me dá tanta raiva, sabe?

Moderadora: Quando foi que você conseguiu se livrar dele?

Duda: Aí, um belo dia eu falei firme mesmo que eu não queria voltar para lá, não é? E eu não fui. Mesmo que berre, se eu tiver que apanhar eu apanho, mas eu não volto para lá e esse homem não vai mais passar a mão em mim. Então isso eu me revolto, porque se fosse hoje eu saberia como reagir, entendeu? Mas eu era uma menina boba, eu tinha pouca idade, eu não tinha experiência.

Lulu: Naquele tempo ninguém...

Duda: Eu era recém chegada do interior, não é? Eu vim de lá com doze anos, eu deveria ter uns quatorze anos, mas eu era boba.

Lulu: Antigamente ninguém escutava o que a gente falava, achava que era impressão, não é?

Duda: Eu comentava com a minha mãe achando que ela iria me ajudar, mas não. (CIDADE DE EMAÚS, grifo nosso)

O processo de dominação ao qual Duda estava sujeita não vinha apenas do TID e sim do modo como suas relações familiares eram construídas sob o signo da constante ameaça paterna. O dever de obediência para com o pai, baseado na dominação patriarcal (WEBER, 1991b), que fazia com que a, então, adolescente se sujeitasse ao risco de ser abusada para não contrariar a ordem paterna de trabalhar naquela casa. A própria mãe da menina também sofria com a subordinação ao marido e atuava de modo a não contrariá-lo, ainda que essa omissão pudesse ocasionar uma grave violência à filha.

Para conter o assédio do patrão, Duda recorreu a recursos (frágeis) de resistência como, por exemplo, usar várias roupas para dormir ("Eu tinha que vestir short, eu tinha que vestir um bocado de roupa porque eu tinha medo dele me apalpar assim chegar mesmo, não é?”). Até que, num gesto de power to, enfrentou a oposição do pai e tomou a decisão de não voltar àquele contexto de tentativa de abuso sexual. Mesmo sendo tão nova na época (14 anos) e vivendo uma situação duplamente desfavorável, tanto na própria família quanto na casa em que trabalhava, o relato de Duda mostra que ela enfrentou a situação, revelando-se capaz de questionar esse viés da opressão no TID e se posicionando como resistente. 
No entanto, as marcas daquela vivência ainda causam dor e revolta. O sentimento de raiva ao qual Duda se refere exprime indignação e expressa uma injustiça: uma menina não deveria passar por uma situação como aquela e ainda sem contar com o apoio dos pais. Duda, mesmo após tantos anos, ainda apresenta ressentimento em relação à mãe, que não procurou ajudá-la.

Outra participante, Lulu, complementa afirmando que naquela época as crianças não eram ouvidas: "Antigamente ninguém escutava o que a gente falava. Achava que era impressão, não é?”. A nosso ver, trata-se de uma forma de suavizar a violência, fazendo crer que não estava acontecendo o que a criança estava percebendo. Afinal de contas, os patrões eram considerados "boas pessoas", então, se a criança ou a adolescente percebia algo errado, o problema estava nessa percepção, e não na conduta do patrão ou da patroa.

Essa marca também remete a uma ideia da infância e da adolescência como incompletude, como sujeitos que não percebem direito a realidade, o que caberia apenas aos adultos. Assim, a condição da infância era uma condição de inferioridade, como destaca Faleiros: "Nem sempre a infância foi vista como uma fase específica e própria da vida [...]. Até recentemente, no limiar deste século [XX], ela foi definida, inclusive juridicamente, como fase da incapacidade, da tutela, da menoridade, com as obrigações de obediência e submissão”. (FALEIROS, 1998, p. 9, grifo nosso)

Sob outro viés, Eliacheff e Larivière (2012), ao discutirem a fala da criança vitimizada, informam que o que ela diz é recorrentemente subestimado e indicam que essa incompreensão ocasiona um novo trauma pelo fato de a criança não ter sido levada em consideração. De modo correlato, Honneth (2012b) ressalta que faz parte da construção do autorrespeito ainda na infância perceber que suas falas e posicionamentos são considerados confiáveis ou dignos de valor. Portanto, ignorar ou mesmo menosprezar a denúncia de violência é realizar um novo ato violento, pois pode fazer com que a criança ou adolescente permaneça na situação inicial de sujeição, além das repercussões dessa recusa à escuta poderem, elas mesmas, provocar o sentimento de rebaixamento moral desses sujeitos. Não por caso, a recusa da família é tão destacada no relato de Duda sobre a tentativa de abuso do patrão.

Outros fatores que destacam a "inferioridade" da menina empregada doméstica são os preconceitos relacionados à condição social e à cor da pele, que estimulam violências e impunidade: 
Heloísa: [...] Tem pessoas, tem patrões que, além deles violentarem as empregadas, ainda mantém elas por ameaça. Aqui mesmo eu conheço uma menina, hoje ela mora pra cá pra... Ela foi morar em Panorama [conjunto popular] e o filho da patroa dela começou aliciar ela. Quando foi um dia, ele agarrou ela jogou ela lá no mangueirão [área ao redor de um estádio de futebol] e ela disse que não ia ficar lá sozinha com ele porque ele era saliente, a mulher [patroa] disse que ela... Que era mais fácil ela se salientar para o lado dele do que ele para o lado dela. Depois disso, ele agarrou ela. Quando ela chegou no domingo, ela contou para a mãe dela, a mulher disse na cara dela que era mentira, que ela não iria levar o filho dela para fazer exame coisa nenhuma, porque o filho dela jamais iria se deitar com uma pretinha. E hoje em dia essa filha dela tem doze anos com esse homem.

Moderadora: Ela engravidou?

Heloísa: Engravidou. Então ela [a patroa] disse assim: 'olha, Nenzinha, conversa com a tua filha para ela dizer quem é o pai do filho dela porque eu tenho certeza que meu filho jamais iria fazer uma coisa dessas com uma empregada'.

Tati: E para quê existe exame de DNA?

Heloísa: Quer dizer que, aí, tanto a pessoa ela é humilhada de todas as formas e ainda é discriminada. Então, às vezes, a necessidade é tanta que sabe lá o tipo de abuso que ela não sofre mais devido à necessidade. Ela pensa que tem que ajudar, não é? Aí fica lá, encara. (CIDADE DE EMAÚS, grifo nosso)

O caso que Heloísa relata mostra a adolescente como vítima por dois motivos: a violência sexual e discriminação (social e racial). A patroa nega-se a acreditar que o filho poderia ter tido vontade de manter relações sexuais com uma "pretinha" e, menos ainda, que o tenha feito de fato. Mesmo com a gravidez e o nascimento da criança, a ex-patroa continua negando o ocorrido: o filho dela “jamais iria fazer uma coisa dessas com uma empregada”. Evidencia-se assim o preconceito social e o modo inferiorizado como a menina empregada era vista por aquela família, afinal de contas, o filho da patroa jamais faria "uma coisa dessas”, ou seja, ter um filho com a empregada.

A culpa ainda é transferida para a adolescente quando a ex-patroa cobra da mãe da menina que busque a verdade sobre o nome do pai da criança, especulando que a adolescente tivesse um relacionamento com outra pessoa. Mesmo tendo "certeza" da inocência do filho, a ex-patroa negou a possibilidade de o filho realizar exame que poderia comprovar a violência sexual e a paternidade. Embora a própria adolescente se posicione como vítima, a postura da entrevis- 
tada ao contar o relato demonstra clara percepção crítica da situação vivenciada pela jovem, mesmo que haja, por parte dela, a necessidade de atribuir explicação, um motivo em razão do qual uma menina pode se sujeitar a tamanha humilhação: a necessidade.

No grupo do "sindicato", a discussão sobre abuso sexual ganhou corpo a partir dos relatos de Zezé e Lenyta:

Zezé: Na casa de família que tem patrão nojento. Ele vem, a gente está lavando uma louça, ele vem esfregando aquela coisa nojenta dele atrás da gente. Disfarça para pegar uma xícara ou um copo só para estar tirando casca da trabalhadora doméstica. E ninguém vem dizer que isso nunca aconteceu porque acontece, entendeu? E assim trabalhei muito na casa de... Até de advogado, eles tiram graça com a cara da gente e ainda dizem assim: 'se tu falar alguma coisa tu sabes o que vai te acontecer! Eu sou advogado!' Sabes? Entendeu? Então, tudo isso é para mim muito humilhante. O trabalho doméstico é o ultimo. Mas é por isso que nós devemos lutar, para que as outras trabalhadoras, as outras pessoas que vem ai pela frente, vejam o trabalho e que este trabalho pode ser mudado. Ser um trabalho melhor, que não seja um trabalho escravo, seja um trabalho que você tenha todos os seus direito trabalhistas que nós não temos, você entendeu? É por tudo isso.

Lenyta: É porque aconteceu comigo. [...] Ele, assim, ele dizia que me considerava da família, não é? Só que, assim, eu era tão raquítica que daí depois eu fui me desenvolvendo, não é? Fui criando corpo. Quando eu entrei lá, a esposa dele tinha o mais velho, o primeiro dela, não é? Estava com quatro anos, aí, quando eu sai de lá, ela já tinha três, o caçula já estava com uns dez anos, por aí. E ele sempre dizia, quando chegava os amigos dele, dela, não é? Inclusive ela era do interior, ela me tratava super bem e ele também, não é? [...] Eu não tinha o meu quarto, eu dormia com os meninos. [...] Estava deitada e eu tinha o costume de dormir só de calcinha. Eu praticamente era uma criança, porque nem seios eu tinha, não é? Aí, quando eu me espantei, aquele peso. Eu achava que fosse o menino, não é? Aí eu simplesmente passei a mão assim, porque quando ele acordava, ele ia para a minha cama, não é? Passei a mão e senti a diferença, não é? Aí eu dei aquele pulo, o que eu olhei era ele. Aí lá mesmo ele ficou, aí eu me levantei, bati no quarto dela e disse 'dona Maria, o senhor José foi se jogar comigo lá em cima da cama'. Aí eu comecei a chorar e fiz logo aquele escândalo. Só que ele não abusou nada, não é? Simplesmente ele só se deitou e jogou as pernas para cima de mim, mas para mim, ali foi... Não é? 
Ericka: A gota d'água.

Lenyta: Aí, quando foi de manhã, umas dez horas ele acordou, eu fiz o maior barraco, disse que não iria ficar mais lá. Eu chorava para um lado e ela chorava para o outro, as crianças no outro, não é? Porque até de mãe eles já me chamavam, porque quem ficava com eles mais era eu. Aí ela pediu para eu ficar, não é? Eu disse não, eu não vou ficar porque ele já tentou uma vez, vai tentar outra vez e eu não vou responder por mim. Aí eu não sei que... Ainda passei uns quinze dias, não é? Aí, nesses quinze dias, ele não dormiu em casa. Eu acho que com vergonha e depois ele veio me pedir desculpas, perdão. Só que eu não aceitei, porque como eu disse para ele: 'já que você me considerava da família, não era preciso você fazer isso’. [...] Aí, aquilo me decepcionou muito! Aí eu saí de lá, depois de sete anos de convivência com eles, eu saí. E outras casa também que eu já trabalhei, era aqui ou acolá, quando não era ele era o patrão, como ela falou: 'vai buscar uma coisa tem que estar roçando na gente', não é? Eu acho que é uma grande falta de respeito, mesmo. Já que tem compromisso dentro de casa, têm as suas esposas, eu acho que não tem por que isso. Só porque a gente está ali para fazer o serviço deles? Mas essa parte não é nossa. Eu acho totalmente errado.

Zezé: Deixa eu te falar como começou esse caso. Assim, foi um caso. Trabalhava ela era advogada, assim, terrível essa moça! Essa senhora! Mazé o nome dela! E ela vivia com esse homem há oito anos. Eu fui trabalhar lá eu tinha... Eu sei que quando eu engravidei do Elton, eu tinha vinte e dois anos. Eu tinha o quê? Três anos trabalhando com eles. [...] Aí sempre eles brigavam. Vira e mexe eles brigavam. Aí até que um dia ele se separou dela. Ele disse que não ia mais ficar com ela e tal. Foi embora. [...] E eu voltei para a casa da minha madrinha. [...] Aí quando foi, assim, uns quinze dias ele começou a ir lá no colégio. [...] Aí passou um mês, dois meses, ele continuou. Aí, no terceiro mês, ele apareceu, ele tinha um carro. Ele disse 'ah, Zezé, eu queria falar demais contigo'. 'Mentira, senhor Jacir'. Assim sem maldade, para vocês verem como foi sem maldade. Aí eu disse: 'vem cá, senhor Jacir, o que foi que houve?'. 'Não, é porque a Mazé vai voltar e eu quero que você volte para a casa'. Eu disse: 'não, não vai dar certo’. Tá. Aí, depois, no outro dia ele já veio com outra historia. Aí ele disse... Aí eu fiquei pensando. Cheguei em casa e falei para a minha madrinha: 'Sabe madrinha, o Jacir falou isso e isso para mim. Ele disse que ele ia me dar boas condições e a senhora sabe que ele já foi o meu patrão, então ele não vai tentar alguma coisa comigo, eu sou apenas uma empregada maranhense lá dos cafundós do brejo', disse para ela assim. Tá. Aí, da outra vez ele me convidou para sair, pra passear. [...] Eu e uma outra [estudante] sentamos e começamos a conversar. Ele chegou no carro e se parou assim perto 
da gente. Ele disse: 'ei, Zezé, vamos embora? Já terminou a prova?'. Eu disse: 'já, não mas eu não vou, não'. Aí ele desceu e disse: 'tu não queres um refrigerante?' Eu disse: 'não obrigada'. Aí a minha colega disse 'ah! eu quero'. 'Tá, então traga. Para mim é Coca, e para ti?’ e ela disse: ‘É Fanta’. E ele usava um anel e virava e mexia ele perguntava para mim assim: ‘Tu és virgem?', aí eu dizia 'não, eu sou ariana.' Mas eu entendia a pergunta dele, entendeu? [...] E, nesse dia, aí o comerciante viu quando ele apertou o anel e colocou uma coisa dentro da Coca-Cola [...], e eu tomei o refrigerante. Aí eu comecei... sabe quando a gente vê um tanto de estrelinha, aí eu fiquei tonta, tonta, tentei levantar e não consegui. [...] Minha colega disse assim: 'então leve ela para a casa da madrinha dela'. Essa eu ainda ouvi, mas depois eu não vi mais nada. E no outro dia eu amanheci no motel... toda estragada. E daí eu fiquei grávida do menino. Aí, com a minha gravidez, ele me procurou de novo e procurou o meu pai a minha família e disse que queria casar comigo [...], aí eu disse: 'casar com ele é o mesmo que casar com o diabo'. Aí ele foi vendo a minha barriga crescer, não é? Porque eu acho que nessa época eu estava no meu período fértil, não é? Até porque eu não tinha certo tipo de maldade, eu não sabia me prevenir também, não é? [...]. E quando ele viu que eu não iria ficar com ele mesmo, ele pegou e disse que queria que eu fizesse o aborto da criança. Então eu sempre fui muito católica, sempre acompanhei, e eu dizia assim que... E eu sou contra o aborto. [...] Está certo: naquele momento não foi um ato legal como deveria ser, mas também é ilegal tu tirar um filho que não tem nada a ver com aquilo, não é? E eu disse que não, que não. E daí eu desapareci, não é? Minha madrinha me mandou para um outro lugar e eu tive o Elton. Hoje o Elton está com vinte e sete anos e ele nunca soube desse caso. Eu nunca contei para ele assim, para falar para ele diretamente como foi o problema. Aí, quando ele completou quinze anos ele disse que queria conhecer o pai dele, aí eu levei ele, não é? Eu sei aonde ele mora, eu levei ele lá. Ele era registrado só no meu nome. E aí ele pegou e registrou no meu nome e no nome dele. Ele é registrado assim, sabe? Ele reconheceu o filho. Mas até hoje é uma magoa, assim.

Moderadora: Mas tu chegaste a procurar a polícia na época?

Zezé: Cheguei. Cheguei a procurar, mas na época eles disseram que eu era maior de idade e não pegava nada, porque aconteceu... E eles não acreditaram no que eu tinha dito, não é? E eu não tinha testemunha, entendeu? E por isso ficou. Ah, mas é horrível, ate hoje o sexo para mim é um drama. É horrível (SINDICATO II, grifo nosso). 
O relato de Lenyta sobre uma menina franzina que vai ganhando corpo e, com isso, despertando o interesse do patrão é bastante recorrente nas pesquisas acerca do TID. (LAMARÃO; MENEZES; FERREIRA, 2000; ALBERTO et al., 2009) Mesmo tendo pouca idade na época, Lenyta agiu de modo resistente contra o que, no grupo, indicou como falsas promessas relacionadas ao TID, como a de que a menina trabalhadora seria "alguém da família".

Há um componente de power with nessa postura destacada por Lenyta porque cria um terreno compartilhado de questionamento à violência no TID: "essa parte [satisfação sexual do patrão] não é nossa”. Nesse discurso, reside, em algum grau, a percepção de problemas que afetam, em geral, as meninas domésticas, e de um contexto comum a todas elas.

Ao longo de todas as discussões no grupo focal do "sindicato", Zezé manifestou-se radicalmente contra o TID. Essa postura ganha ainda mais coerência a partir do relato do estupro que sofreu de um ex-patrão. A humilhação no TID teria como base relações de power over, a partir das quais o poder do patrão é destacado em comparação com a vulnerabilidade da menina trabalhadora, sujeita aos seus mandos (por ser criança, por ser menina, por ser trabalhadora doméstica). Nesse sentido, os empregadores procuram reforçar essa condição ao criar situações com a finalidade de "se esfregar" nas empregadas, ao ameaçar com base no status social e/ou econômico e ao violentar sexualmente. Essa última encarna uma das faces mais cruéis da dominação no TID. Coíbe a livre disposição do próprio corpo e arrasa a autoconfiança básica dessas meninas e mulheres. Trata-se de um grave desrespeito, seguindo a perspectiva desenvolvida por Honneth (2003).

Mesmo tendo passado por situações extremas provocadas pela inserção no TID e corroborando, inicialmente, um lugar de inferioridade da doméstica ("sou apenas uma empregada maranhense lá dos cafundós do brejo"), Zezé posicionase de maneira resistente ao enfrentar o ex-patrão nas suas tentativas de "consertar o erro" e como sujeito político, na medida em que identifica problemas enfrentados por meninas trabalhadoras domésticas e desvela elementos de power with, ao participar da construção de "pontes semânticas”, que são aquelas capazes de conectar a experiência individual de desrespeito com objetivos coletivos. (HONNETH, 2003)

Por essas razões, Zezé conclui sobre a necessidade de engajamento das trabalhadoras para melhorar as condições para si e para as próximas gerações 
(“Mas é por isso que nós devemos lutar, para que as outras trabalhadoras, as outras pessoas que vem ai pela frente, vejam o trabalho e que este trabalho pode ser mudado"). Ao fazê-lo, a participante aborda a questão como um problema político que concerne a uma coletividade. Há, nesse trecho, a encarnação de um "nós" relacionado às trabalhadoras domésticas: “nós devemos lutar”, lutar por direitos e por condições dignas de trabalho. A construção desse "nós”, de acordo com Melucci (2001), é o que permite articular interesses e dar estabilidade a ações coletivas. Ao mesmo tempo, o próprio envolvimento em ações dessa natureza já pode representar a conquista de um novo olhar para si, na medida em que, ao lutar contra o que provoca o desrespeito, os sujeitos se sentem dignos de valor. (HONNETH, 2003)

\section{Educação}

Educação foi o segundo assunto mais abordado na cobertura jornalística a respeito do TID, com 15,5\% do total de ocorrências. Esse tema figurou de pelo menos dois modos nos jornais estudados: (1) como área mais prejudicada pelo TID em razão das longas jornadas e da reprodução da pobreza, na medida em que o fracasso na escola diminui as oportunidades que crianças e adolescentes teriam de obter sucesso profissional e (2) como saída, com alternativa para que meninas envolvidas no TID possam transformar a realidade em que vivem.

Ainda assim, meninas trabalhadoras domésticas foram posicionadas nas matérias principalmente como vítimas $(79,4 \%)$, cujo principal direito violado é o à educação. Os jornais apontam dados do Instituto de Pesquisa Econômica Aplicada (IPEA) e de outras entidades de pesquisa para comprovar os prejuízos para quem realiza aquele tipo de atividade durante a idade escolar. Essa lógica foi um dos destaques na cobertura inicial acerca do tema em 2000.

Na reportagem "Contra o emprego doméstico infantil”, publicada no Diário do Pará, em 9 de junho de 2000, é realizada uma comparação entre o doméstico e outros tipos de trabalho infantil:

'O serviço doméstico é absolutamente incompatível com uma escolaridade regular', disse ela [Lena Lavinas pesquisadora IPEA], informando que o atraso escolar das crianças que trabalham em outros setores é, em média, de quatro anos, atingindo cinco anos entre as 
domésticas - meninos e meninas que não trabalham têm atraso mé-

dio de três anos. (DIÁRIO DO PARÁ, 09/06/2000)

Desse modo, é possível inferir, a partir da reportagem, que o TID não apenas causa prejuízos à formação escolar como também, dentre outras formas de trabalho infantil, é a mais danosa à escolaridade regular. A educação é tida como um dos principais direitos violados de quem exerce esse tipo de atividade. A longa jornada de trabalho e o cansaço dela decorrente seriam responsáveis pelo não aproveitamento escolar satisfatório e pela falta de interesse na escola, razão pela qual muitas meninas trabalhadoras desistem de frequentar as salas de aula.

Diversas pesquisas apontadas na cobertura dos jornais ratificam esse discurso. Em 2002, Unama, Cedeca-Emaús e Unicef realizam um levantamento com crianças de 7 a 14 anos de escolas públicas das capitais dos estados da Região Norte. Os prejuízos educacionais ocasionados pelo TID foram destacados no noticiário sobre os resultados do estudo.

Mais preocupante que os índices são as consequências desse trabalho que compromete o desenvolvimento físico, psíquico e intelectual da criança. 'A maioria, além de apresentar dores no corpo devido ao peso dos bebês, não consegue assimilar os estudos', diz Garcia [Lúcia Garcia, coordenadora da pesquisa]. (DIÁRIO DO PARÁ, 26/07/2002)

Ao longo da cobertura da temática "educação" relacionada ao TID, principalmente nos primeiros cinco anos, o discurso mais acionado pelos media é o de que esse tipo de trabalho infantil destrói as chances de a menina trabalhadora ter sucesso na escola. Assim, o lugar atribuído a essas pessoas foi, sobretudo, como vítimas. Seja porque estão perdendo a oportunidade de crescer na vida por meio da educação, seja porque aceitam de modo submisso as imposições dos patrões. Trechos da reportagem publicada em 0 Liberal, em 8 de setembro de 2002, são claros a respeito desse posicionamento:

Para muitas meninas, o sonho de estudar e ter uma profissão acaba quase sempre na dura realidade do trabalho infantil doméstico. Acordar cedo, lavar, passar, cozinhar e ainda ter que cuidar dos filhos da patroa. Uma rotina aceita sem questionamentos. [...] 
No dia 10 de dezembro, A. F. comentar que vai completar 18 anos. Ela diz que quer ser professora e que está fazendo supletivo. O problema é que não vem sentindo muito estímulo para estudar. O motivo é o cansaço. [...] 'É muito pesado. Fico cansada, sem vontade para estudar', comenta. [...]

Apesar da vida que leva, A. F. se resigna e justifica o baixo salário dizendo que a patroa é professora e, portanto, 'já ganha pouco, quase nada'. Mas a vantagem é que ela é uma pessoa legal e que, 'graças a Deus', nunca me tratou mal. (O LIBERAL, 08/09/2002)

A vitimização da adolescente por meio do reforço, por parte do discurso do jornal, dos modos de dominação no TID se manifesta na resignação atribuída à trabalhadora doméstica, que não questiona a dura rotina e também não exige o salário integral. Apesar de atribuir uma função significativa à educação, a ponto de querer ser professora, a adolescente já em defasagem idade-série afirma que não se sente estimulada a estudar em razão do cansaço. Quanto ao baixo salário, ele é justificado pela alegação de que a patroa também ganha pouco, mas a remuneração insuficiente seria compensada pela ausência de maus-tratos, considerados comuns no caso de meninas trabalhadoras domésticas. Tão comuns que a adolescente se refere a uma "graça divina" o fato de não ser maltratada. O caso em tela desvela um componente de aceitação e submissão a uma relação de power over, na qual a adolescente tem boa parte de seus interesses e oportunidades cerceados pela patroa e pela própria condição mais ampla do TID. Porém, como defende Haugaard (2012), relações de poder dessa natureza não apresentam um resultado de soma zero, ou seja, os interesses em conflito não são mutuamente excludentes (GIDDENS, 1998), porque, de outro modo, "a complacência disposta seria improvável”. (HAUGAARD, 2012, p. 25, tradução nossa) Nesse sentido, a vantagem que faz com a adolescente aceite essa situação é o fato de se sentir bem tratada e, provavelmente, o medo do risco de mudar de casa e passar por restrições piores ou violências.

Outro ponto bastante abordado quando o tema era educação foi a perpetuação da pobreza. Especialistas chamados a se pronunciar nos media sobre o TID apontam que esse tipo de atividade alimenta um ciclo de pobreza na medida em que crianças empregadas domésticas serão empregadas domésticas adultas. Entre as situações descritas por especialistas como as que causam negação do 
direito à educação estão: cansaço, mudanças de escola, falta de tempo e de local adequado para estudar. Meninas domésticas raramente possuem privacidade quando moram em casas de família e, portanto, na maioria das vezes, não dispõem de um espaço reservado para realizar tarefas escolares e se preparar para as avaliações.

'Uma criança que trabalha conspira contra seu desenvolvimento, será um adulto pouco qualificado e não poderá cobrir as necessidades básicas de sua família e seus filhos terão que trabalhar, em um círculo de pobreza que se repete', diz Patricio Cuevas, da sede chilena da 'World Vision Internacional'. (O LIBERAL, 08/08/2004)

Dessa forma, a negação de um processo educativo adequado e a inserção precoce de meninas nos serviços domésticos estimulariam a perpetuação da pobreza porque limitariam as condições reais de essas crianças e adolescentes alcançarem um outro tipo de inserção profissional. Histórias de mulheres que permaneceram no emprego doméstico também foram noticiadas:

A doméstica Socorro Aleixo exemplifica bem a situação de grande parte das trabalhadoras domésticas do Estado do Pará. Ela tem 38 anos e garante que já trabalha há 30 anos 'na casa dos outros'. Está há cinco anos na casa de seus atuais patrões, ganha um salário mínimo, mas nunca teve a carteira assinada. (DIÁRIO DO PARÁ, 15/05/2006)

Desde os oito anos de idade, Socorro trabalha como doméstica em casas de família. Entretanto, mesmo adulta, não tem todos os seus direitos respeitados, já que há mais de cinco anos trabalha sem carteira assinada. A precariedade da situação trabalhista das empregadas domésticas é exposta e demonstra a dificuldade enfrentada por meninas que começaram a trabalhar "na casa dos outros" desde crianças para romper com o ciclo da pobreza. O relato de Socorro contradiz uma das promessas relacionadas ao TID, a de que seria uma oportunidade de buscar sucesso na vida. Na verdade, a inserção precoce nessa atividade contribuiu para reforçar o contexto de desigualdades no qual está inserida. Nesse sentido, não ter os direitos trabalhistas respeitados ao longo de 30 anos de trajetória laboral demonstra que ela encontra-se à margem, que não possui o mesmo status de igualdade moral que outros trabalhadores, o que podemos compreender, 
a partir de Honneth (2003), configura-se como um desrespeito que limita a autonomia pessoal, afeta a integridade social e o autorrespeito.

Apesar do enfoque nos prejuízos educacionais, há brechas no noticiário, materializadas por meio do depoimento de cidadãos comuns, que intuitivamente atribuem valores positivos relacionados ao TID. Em uma matéria de 2 de outubro de 2004 sobre uma passeata contra o trabalho infantil organizada pelo Fórum Paraense pela Erradicação do Trabalho Infantil e Proteção do Adolescente, há o depoimento da professora Maria de Belém, do Educandário Jesus de Nazaré, localizado na capital do Pará. Segundo ela os alunos faltam, muitas vezes, por terem que trabalhar:

Ela lembrou que uma aluna de nove anos, cujo nome preferiu não citar, trabalha todas as tardes, 'inclusive aos domingos', como babá de uma senhora de 68 anos. 'Essa aluna é bem tratada, ganha o dinheirinho dela, mas não tem tempo para estudar em casa e, pior, nunca tem tempo para brincar', disse Maria de Belém. (DIÁRIO DO PARÁ, $02 / 10 / 2004)$

O valor positivo atribuído ao trabalho doméstico está na possibilidade de ganhar dinheiro por conta própria, materializada na expressão "ganha o dinheirinho dela”, e complementada pela informação de que a criança é bem tratada. No entanto, por que se usa o diminutivo para ser referir ao valor recebido pelo trabalho de crianças e adolescentes? O que significa essa ideia do "dinheirinho"? Ganhar o dinheiro como resultado do esforço pessoal por meio do trabalho é, para nossa sociedade, algo valoroso. Nesse sentido, "dinheirinho" pode se referir a um "ganhar pouco justificado". A justificativa para tanto pode ser pelo fato de ser uma criança ou um adolescente que realiza o trabalho. Assim, por ser um sujeito em desenvolvimento, não merece o valor integral, ou ainda por ser um tipo de trabalho pouco valorizado, de tal modo que o ganhar menos poderia significar ainda trabalho de menos.

Essa perspectiva foi corroborada no grupo focal com adolescentes do "centro de formação", que fizeram menção à ideia de que adolescente deve ganhar pouco porque não sabe como usar o dinheiro (p. 215 deste livro). Outra possibilidade é que ganhar dinheiro próprio, o "dinheirinho" da criança, seria uma forma de ela conseguir comprar suas "coisinhas", uma forma bastante usual pela qual 
as pessoas, inclusive as próprias adultas ex-trabalhadoras infantis domésticas, referem-se aos objetos que as adolescentes compram ou gostariam de comprar com o dinheiro adquirido por meio do trabalho em casas de família, conforme discutiremos na seção sobre os grupos focais.

Em uma matéria sobre o dia da empregada doméstica (27 de abril), o jornal apresenta dados sobre um estudo realizado pela OIT, segundo o qual a maioria das trabalhadoras domésticas está na informalidade. O periódico também informa que a situação das crianças nessa atividade ainda é pior. Uma adolescente é usada como personagem:

É o caso da menina Elizabeth, de 15 anos, que vive no Recife (PE) e recebe $\mathrm{R} \$ 30^{13}$ mensais para cuidar do filho de uma vizinha. Além disso, ajuda a tomar conta dos irmãos menores em casa. Elizabeth está dois anos atrasada na escola. Ela segue o caminho profissional da mãe, que tem 44 anos, sempre trabalhou como doméstica e nunca teve a carteira assinada. (DIÁRIO DO PARÁ, 28/04/2007)

Ao fazerem referência à quantia irrisória que a adolescente recebe pelo trabalho que realiza e pelo atraso escolar, evidencia-se, nessas matérias, a condição de subalternidade desses sujeitos afetados pelo TID. Tal condição se conforma principalmente pela afirmação de que a menina está trilhando o mesmo caminho que a mãe, que, mesmo com 44 anos de idade, nunca teve seus direitos trabalhistas garantidos. Nesse sentido, a ausência da garantia dos direitos trabalhistas da mãe repercute nas possibilidades de futuro da adolescente trabalhadora.

Especialistas e agentes do Petid, quando fontes nas matérias, buscaram ainda problematizar aspectos relacionados a políticas públicas de assistência social e educação. Uma das principais críticas era o programa de transferência de renda, que apenas exige frequência à escola, mas não contribui efetivamente para eliminar o trabalho infantil, como podemos observar nos trechos a seguir:

Para a educadora social Renata Santos, do Centro de Defesa da Criança e do Adolescente (Cedeca), os programas de transferência de renda são insuficientes para garantir que as crianças não voltem à situação de trabalho e que apenas controlar a freqüência escolar

13 Nesse ano, o valor do salário mínimo era de $\mathrm{R} \$ 380,00$. 
não significa garantir que a criança terá condições melhores. ‘[...] Acredito que só ir até a escola e pegar a frequência escolar não adianta. Desse jeito não se sabe que qualidade. É preciso incluir a família, trabalhar com ações educativas, dar oportunidade de geração de renda. Até porque o valor da bolsa é muito inferior ao que uma família precisa para viver'. (O LIBERAL, 07/08/2008)

Segundo a socióloga [Maria Luiza Lamarão], é preciso que a escola também ofereça maior infraestrutura para realizar atividades que vão além do ensino. 'É preciso ter ensino, mas também pesquisa e esporte, que leve a criança ou adolescente para a formação de um futuro melhor’. (DIÁRIO DO PARÁ, 13/06/2009)

Há, desse modo, uma crítica dos agentes sociais e especialistas em relação às condições concretas que as escolas possuem para manter crianças e adolescentes interessados e aprendendo com qualidade. Se num primeiro momento, o discurso em torno da educação relacionada ao TID era dos prejuízos que o último causa à primeira, nos últimos anos analisados esse discurso se complexifica por meio da atenção dos atores sociais à qualidade da educação oferecida. Nesse sentido, não haveria como retirar as crianças da situação de trabalho, ainda que com incentivo de programas de transferência de renda, se as escolas não estão preparadas para oferecer oportunidades de aprendizado que levem a um futuro profissional distinto. Assim, crianças e adolescentes envolvidas no TID não seriam apenas vítimas de maus-tratos ou da falta de oportunidades, mas também da ineficiência do Estado.

O posicionamento desses sujeitos como vítimas é reforçado ainda por descrições sobre o dia a dia de meninas trabalhadoras domésticas que tentam conciliar estudo e trabalho:

W.F. faz aniversário no próximo dia 10 de julho. Prestes a completar 15 anos, ela não vai ter baile, presentes, quiçá um bolo de aniversário. Para ela, este dia será apenas mais um de muito trabalho. A rotina é desgastante: ela acorda às $5 \mathrm{~h}$ em busca de um espaço no ônibus lotado que sai do distrito de Outeiro rumo ao centro da cidade, onde trabalha há um ano como doméstica. Ela lava, passa, limpa, cozinha e cuida de uma criança de três anos, para receber no final do mês 
$\mathrm{R} \$ 200,00 .{ }^{14}$ Uma renda que além de ajudá-la no sustento, é dividida com o restante da família, que inclui mais cinco irmãos, e mora no município de Irituia, no nordeste paraense.

Depois de quase 12 horas de trabalho, ela segue para escola, onde quase sempre chega depois do primeiro horário. Repetindo pela segunda vez a sexta-série do ensino fundamental, ela tenta levar adiante aquele sonho que sempre ouviu falar que seria seu passaporte para uma vida melhor: os estudos. 'Minha mãe sempre me disse que tinha que estudar para ser médica', disse. Mas o cansaço, na maioria das vezes, fala mais alto. 'Não sou boa aluna. Me dá sono, às vezes esqueço de fazer a lição. Acho que vou parar mesmo assim que terminar o ensino médio. Quero conseguir uma vaga no comércio. Quem sabe assim tenho mais tempo para estudar e dinheiro para pagar um cursinho para o vestibular?', acredita.

De corpo esmirrado, a jovem que deve ter no máximo $1,5 \mathrm{~m}$, já traz na aparência o desgaste de quem já está na lida há mais de sete anos, desde quando morava no interior. 'Desde que era criança sempre trabalhei. Primeiro eu ajudava minha mãe cozinhando e cuidando dos meus irmãos. Depois fui trabalhar de babá, doméstica em casas de família, é muito cansativo, mas acho que já acostumei', disse a garota, que da infância, a única lembrança de brinquedos que tem é os das crianças que ajudava a cuidar. (O LIBERAL, 02/07/2009, grifo nosso)

Rotina exaustiva, diversidade de tarefas, longa jornada de trabalho, grave atraso escolar, salário inferior à metade do salário mínimo na época ( $\mathrm{R} \$ 465,00)$, sonho de ser médica abandonado após a situação de fracasso na escola (exemplificada pela repetida repetência da sexta-série), corpo que sofre com marcas do TID, perda da infância e, por fim, a resignação: "é muito cansativo, mas acho que já acostumei”. Essa construção discursiva marca o posicionamento da adolescente como "vítima” porque faz referências explícitas à situação de sujeição da trabalhadora infantil doméstica ao mesmo tempo em que demonstra conformismo em relação à situação em que vive. Embora a adolescente demonstre imaginar outras possibilidades de ocupação no futuro, como trabalhar no comércio e prestar vestibular, o discurso do jornal demonstra certa descrença nessa pers-

14 Naquele ano, o salário mínimo era de $\mathrm{R} \$ 465,00$. 
pectiva quando afirma que ela "acredita" que isso pode ocorrer. Nos outros trechos em que ela foi ouvida, a referência no texto era por meio do verbo "dizer". No entanto, quando ela diz das suas expectativas de futuro, o verbo utilizado é o "acreditar".

Em outras matérias, a volta aos estudos, ainda que como plano, é considerada uma forma de superação da condição precária de agregada ou trabalhadora infantil doméstica, especialmente quando se trata de adolescentes beneficiadas pelo Petid. Na reportagem do Diário do Pará, de 23 de outubro de 2003, sobre história de uma adolescente que sofreu maus-tratos na casa de uma promotora de justiça, o retorno aos estudos é considerado um modo de resistência:

\begin{abstract}
Atualmente I.M. é atendida pelo Cedeca, onde recebe uma bolsa no valor de um salário mínimo, participa de ações educativas e recebe acompanhamento psicológico e de assistentes sociais. 'Estou retomando meus estudos porque parei na $4^{\mathrm{a}}$ série. Sei que perdi a minha infância trabalhando, mas agora estou tentando recuperar o tempo perdido', avalia. (DIÁRIO DO PARÁ, 23/10/2003)
\end{abstract}

Segundo a reportagem, I. M na época tinha 17 anos e havia começado a trabalhar desde os sete anos. A patroa, embora fosse promotora de justiça, havia sujeitado a menina a cárcere privado e feito restrições relacionadas à alimentação. Nesse caso, a referência à resistência não é em relação à situação que a adolescente vivia no TID, mas sim resistência em relação à condição geral de trabalhadora infantil doméstica. Dessa forma, vislumbrar, imaginar outra possibilidade como espaço de resistência, de fuga daquela realidade seria, em si, uma forma de resistir. No entanto, de maneira distinta da adolescente personagem na matéria anteriormente citada, nesse caso a resistência à condição de trabalhadora doméstica, a partir de indícios no texto, é considerada possível em razão de ela estar sendo beneficiada pelo Cedeca-Emaús e de ter acesso à bolsa e aos atendimentos social, educativo e psicológico. Portanto, a existência de um contexto de acompanhamento e assistência estimula o discurso de que a transformação naquelas condições de vida é possível.

Outro forte indício de resistência relacionado à tematização da educação pelos media foi identificado em um gesto de distanciamento que a adolescente personagem da matéria procurou fazer em relação ao discurso de vitimização 
adotado pelo jornal. Trata-se de uma das meninas atendidas pelo Cedeca-Emaús que foi ouvida, recorrentemente, ao longo dos 10 anos de cobertura analisada.

Por três meses, aos 13 anos, Aline Abrahão, hoje com 19, cuidou de um bebê, filha de uma vizinha, no bairro da Marambaia. Recebia o que a patroa quisesse lhe pagar, não pedia nada em troca do trabalho. Foi uma fase rápida, mas cuja experiência ela não esquece. Ela não sofreu maus-tratos, diferente de Marielma. Abandonou o trabalho antes porque a família teve força para lutar contra o desemprego. Estudante do curso de Letras, ela quer passar no vestibulinho da Universidade Federal do Pará para se tornar jornalista. 'Foi uma situação que aconteceu quando meu pai ficou desempregado, mas não parei de estudar, graças à Deus, ao contrário do que acontece com muitas meninas domésticas, que acabam perdendo o interesse pela escola ou ficam sem oportunidade', disse.

Os passos para seguir a carreira de Jornalismo ela começa a dar na produção do fanzine do Programa de Enfrentamento ao Trabalho Infantil Doméstico (PETID) [...] 'Aqui, são atendidas meninas que corriam risco de irem parar em casas de família ou que já são domésticas. Gosto de ministrar oficinas, mas não me vejo mais como integrante do programa, venho para contribuir porque tenho vontade de trabalhar num projeto social', comentou. (DIÁRIO DO PARÁ, 11/06/2006, grifo nosso)

A adolescente ouvida busca, em cada proferimento no texto, distanciar-se da visão de assujeitada pelo TID. Embora o discurso do jornal tente aproximá-la dessa condição ("aos 13 anos”, "recebia o que a patroa quisesse lhe pagar”, "cuja experiência ela não esquece”), ela procura reforçar a distância entre o que ocorre geralmente no TID e o que viveu. Por essa razão, Aline menciona que o trabalho como babá foi temporário e que não deixou de estudar por conta dele "ao contrário do que acontece com muitas meninas domésticas”. O mesmo movimento discursivo é feito pela jovem quando afirma que participa do Petid não como beneficiária, mas como pessoa interessada em realizar trabalhos sociais: "Gosto de ministrar oficinas, mas não me vejo mais como integrante do programa [...]”.

Por que ela resiste a esse posicionamento de vítima? De modo mais abrangente, a resistência é à identificação de si como trabalhadora doméstica, o que 
significaria certo rebaixamento moral por se tratar de uma atividade considerada pouco digna de valor. Ao resistir a esse enquadramento, ela recusa esse lugar inferiorizado socialmente e busca construir outro posicionamento de si, como ao destacar a atuação voluntária em um projeto social, ação de goza de certo prestígio na nossa sociedade. Ao mesmo tempo, o próprio jornal, que tenta reforçar a situação de vítima de Aline, é que, última instância, abre brechas no discurso jornalístico para que ela projete publicamente essa outra condição de si. Nesse sentido, quando o jornal informa que Aline é estudante do ensino superior, também provoca uma distância não tão evidente entre as possibilidades que ela teve de conseguir mudar de carreira e entrar na faculdade e as (im) possibilidades de tantas outras meninas empregadas domésticas que possuem a universidade como sonho distante.

PERCEPÇÕES SOBRE EDUCAÇÃO NOS GRUPOS FOCAIS

Por meio das discussões nos grupos focais e da observação do modo como meninas e mulheres ex-trabalhadoras infantis domésticas atribuíram lugares e posicionamentos a si e a outras naqueles contextos, identificamos três significações culturais mais recorrentes acerca da relação entre educação e TID: a) TID como oportunidade de estudar; b) TID como prejudicial à educação e c) estudo como oportunidade de crescer na vida.

Sobre o primeiro sentido, mobilizado, sobretudo, pelas mulheres mais velhas não sindicalizadas, o TID foi considerado uma forma de ter melhores condições de estudo, em comparação à época em que viviam com suas próprias famílias e tinham que trabalhar na roça. Outro agravante da situação anterior é que, nas áreas rurais, a distância entre a casa da criança e a escola era maior, e ir às aulas demandava muito esforço por parte delas.

No grupo das empregadas domésticas do condomínio de classe média alta, todas relataram terem começado a estudar com dificuldade e bastante atraso. Duas em especial destacaram que o trabalho doméstico é que propiciou melhores condições de estudo, seja por conta da proximidade com a escola, seja por conta da dedicação da patroa. 
Moderadora: E em relação à escola? Porque vocês reclamaram no inicio que não tiveram sucesso na escola porque não se empenharam e tal, mas vocês acham que foi a falta de empenho ou de condições? [...]

Karla: Era falta também de... No meu caso eu acho que era também devido a eu trabalhar, não é? Porque eu tinha que acordar cedo... Quando estudava à tarde, tinha que vim lá do sítio, não é? Vinha, tomava banho para trocar de roupa para ir pra aula e já era longe lá, não é? Lá do sitio, porque eu ajudava o pai e a mãe. Quando chegava, tinha que tomar banho, às vezes nem comia direito, não é? Aí, já ia pro colégio, aí já não tinha aquele aprendizado. [...] Muito longe, aí, às vezes o professor dava uma carona para gente, aí ia no carrinho dele, ele dava carona, quando não, a gente vinha no sol quente. Aí só fazia trocar de roupa e ia embora de novo, meio dia, uma hora, naquele sol quente. Aí desestimulava a pessoa de estudar. Eu acho que também pode ter sido isso, não é? Não dava aquele ânimo para estudar. Aí ia trabalhar e quando chegava já de noite, já cansada.

Wanderléia: Eu fui estudar mesmo, saber o que era sentar em uma sala de aula para estudar, estudar mesmo de cabeça, depois que eu comecei a trabalhar com treze anos na casa desse prefeito. Porque, aí, lá eu não fazia nada, tinha meu tempo para estudar, só era cuidar do menino. Mas quando eu morava com a mamãe que a gente trabalhava na roça, era que nem ela estava dizendo, a gente andava e não era pouco não, era só quatro, cinco quilômetros para chegar na escola.

Tamires: Eu comecei a estudar com quatorze anos, mas antes, no interior, eu estudava, mas do jeito que elas estão falando, aqueles quilômetros da escola. Quando eu comecei a estudar com quatorze anos, a primeira prova que eu fiz, eu tirei zero [risos]. Aí, a minha patroa, essa que eu fiquei até os dezoito, que foi a única que me colocou para estudar, ela disse assim: 'eu vou te colocar em uma aula de reforço'. Me colocou na aula de reforço. No outro ano eu repeti a mesma serie. Só tirava dez em tudo que era matéria. Aí ela chegava para os filhos, que eles estudavam em série igual a minha, quer dizer mais adiantado, não é? 'Vocês estão vendo? Ela trabalha e vocês estão tirando essas notas, não sei o quê....' Falava, não é? Foi no outro ano, passei, e no outro passei e passei dos meninos todinhos, mas quando cheguei em uma certa... Eu comecei a dar falha, não é? De interesse. Éfalta de interesse meu, como ela até hoje diz para mim: 'se tu tivesses continuado, hoje tu já era formada uma engenheira igual o meu filho'. [...]

Karla: Eu acho que vou voltar a estudar para pegar uma carteirinha.

Wanderléia: Não, porque todo ano chega... Já era para eu ter terminado o meu terceiro ano por falta de interesse mesmo, mas esse ano eu já botei na minha cabeça que eu vou voltar fazer o supletivo. 
Tamires: Ela [a ex-patroa] pergunta: 'tu não estás arrependida?' Se arrependimento matasse, eu estou muito arrependida, porque eu fui até a quinta serie, mas até a quinta série eu só tirava dez.

Karla: Estudou até a quinta foi?

Tamires: Até a quinta, mas era só dez que eu tirava em todas as minhas provas. [...] E eu trabalhava e estudava de manhã e o meu trabalho não era aquele trabalho escravo, era só ajudar ela ali, limpava o quarto dela e ia para o colégio. Não era aquele trabalho de cuidar da casa toda, não.

Wanderléia: Pois é. Eu já botei na minha cabeça que esse ano eu vou fazer o supletivo. [...]

Tamires: Em pensar que meus filhos já terminaram os estudos todinho. Já fizeram até. Tem um que está tentando entrar na faculdade e não consegue entrar, não é? E eu começar a estudar... Ah não, não tenho mais paciência. (CONDOMÍNIO, grifo nosso)

Na opinião delas, o trabalho que trazia prejuízos à educação era aquele realizado junto às famílias de origem. Nesse sentido, atribuir valor positivo às possibilidades de educação propiciadas pelo TID se torna um modo de fazer referência à superação de uma situação anterior ainda mais desfavorável, como as mencionadas por Tamires e Wanderléia, que começaram a estudar "mesmo", segundo elas, aos quatorze e aos treze respectivamente, após irem "para” casas de família.

Elas não associam o TID com as razões para o fracasso na escola. Pelo contrário, as entrevistadas informam que a partir do TID tiveram maior oportunidade de estudar. Duas nuances contidas nessas falas devem ser destacadas: a) o TID trouxe vantagens para a frequência à escola, por ser menos exaustivo que o trabalho na roça e por ser realizado na cidade, onde há condições de transporte mais favoráveis; b) o TID causou prejuízos significativos ao processo educacional dessas mulheres que abandonaram os estudos. A primeira assertiva articula-se com a realidade precária da educação nas zonas rurais dos municípios de origem. Nesse caso, o trabalho em casa de família ofereceu uma oportunidade real de inserção na escola em condições melhores do que nos lugares em que viviam. Em princípio, portanto, a oferta de melhor acesso à escola não significava uma promessa, mas uma conquista advinda com TID. Entretanto, além do acesso, era necessário que elas tivessem condições de aprender com qualidade, o que 
ia de encontro ao cansaço, a quantidade de atribuições e as longas jornadas do trabalho doméstico. Esse aspecto não foi trazido à discussão pelas participantes, que tenderam a justificar o fracasso na escola em razão da culpa pessoal ("Eu comecei a dar falha, não é?”).

Sobre esse assunto, Souza (2009) argumenta que o próprio sistema educacional brasileiro não estimula o desenvolvimento dos alunos que advém de classes não favorecidas. "Na realidade, a escola, pensada isoladamente e em abstrato, vai apenas legitimar, com o 'carimbo do Estado' e anuência de toda a sociedade, todo o processo social de produção de indivíduos para o sucesso, de um lado, e dos indivíduos 'nascidos para o fracasso' de outro". (SOUZA, 2009, p. 18) Segundo esse autor, como discutimos no capítulo três, existe um contexto social opaco que "legitima a dominação social", na medida em que os privilégios são considerados justos porque merecidos. A escola, sob a lógica meritocrática, acaba por punir e reforçar como mau aluno "crianças da ralé, para quem o aprendizado das disposições afetivas que serão exigidas pela escola [como capacidade de concentração] lhes é algo estranho e externo". (SOUZA, 2009, p. 413, grifo nosso) Soma-se a essa perspectiva o contexto desvantajoso do exercício do TID para os estudos e, desse modo, a percepção individual da culpa pelo insucesso na educação mostra-se como resultante de um processo ideológico de dominação a partir do qual a crença na igualdade de oportunidades faz com que as desigualdades sociais sejam consideradas justas. Essa lógica nos ajuda a compreender porque, por vezes, as meninas e mulheres entrevistadas têm dificuldade de trazer para linha de frente de seus discursos condições mais estruturais que fizeram com que a elas fossem negadas certas oportunidades.

No caso de Tamires, ela ressalta que a patroa cumpriu a promessa de matriculá-la na escola. De certa forma, quando são crianças ou adolescentes exercendo serviços domésticos, é esperado pela menina e pela família de origem que os patrões providenciem para que ela frequente a escola. No entanto, essa decisão, em geral, cabe aos patrões que, por vezes, não cumprem essa promessa. (MOTTA-MAUÉS, 2008) Assim, Tamires mostra-se grata à patroa que se preocupou com seus estudos e até providenciou aulas de reforço em certo momento. A participante demonstra ainda o orgulho por ter conseguido melhorar as notas e que, apesar de não ter concluído a educação básica, "até a quinta série só tirava dez", a ponto de a patroa a utilizar como exemplo para cobrar melhor desempe- 
nho dos filhos. Esse fato é tratado como uma conquista que estimula uma autorrelação positiva.

Alguns elementos apresentados pela participante corroboram essa ideia da "boa patroa", como o serviço que exercia não ser "aquele trabalho escravo, era só ajudar ela ali, limpava o quarto dela e ia para o colégio. Não era aquele trabalho de cuidar da casa toda não" e o fato de tê-la "colocado para estudar", ainda que fosse em escola pública, enquanto que os filhos da patroa iam a escolas particulares. Nesse sentido, insistir na ideia de que a ex-trabalhadora doméstica poderia estar formada tal como o filho da patroa reforça a vitimização, destacando a culpa individualizada, algo como "te dei condições, você não aproveitou”. Assim, a exigência de resultados iguais nesse contexto de forte desigualdade revitimiza a ex-trabalhadora doméstica que precisa lidar com a culpa por não ter seguido adiante nos estudos e exime a patroa por qualquer responsabilidade sobre isso. A nosso ver, aquele tipo de cobrança configura-se numa forma de desrespeito, que age sobre a compreensão que a ex-trabalhadora infantil doméstica tem de si.

Para outra participante, Karla, estar na escola atualmente teria uma única vantagem, que seria pagar apenas metade do valor das passagens de ônibus. Isso porque em Belém, todos os estudantes têm direito à meia-passagem no transporte público. Sobre esse ponto especificamente, concordamos com a formulação de Souza (2009), segundo a qual o que está em evidência é a preocupação com as necessidades imediatas, e não uma preocupação com um planejamento do futuro ou em, por exemplo, voltar a estudar para buscar melhores condições de vida.

No grupo da "cidade de Emaús”, o fracasso escolar também é apontado com resultado de uma falta de esforço individual:

Lulu: Aí, quando chegava, essa família que tomava conta de mim, quando eu chegava, eu ia tomar banho, aí vinha e jantava e eles me botaram para estudar não é? Aí iam me ensinar na carta do $\mathrm{ABC}$ tudinho botava... Tanto que hoje em dia eu tenho a segunda série, mas eu sei coisa que o pessoal da quinta série do primário não sabem. Eu ensino, porque no meu tempo a professora fazia, assim, uma roda no papel, botava em cima da letra para a gente acertar. Se não acertasse era palmatória na mão. Aí, tinha o dia da sabatina, que era o dia da tabuada. A gente tinha que estudar, estudar [...]

Moderadora: Me digam uma coisa [...] 
Lulu: Por isso que hoje em dia eu sou boa em matemática, porque eu queria sempre ser a primeira da classe.

Acácia: Eu sou ruim em matemática, eu sou ruim em português [...]

Lulu: Ah! Não. Eu não queria apanhar dia de sabatina [...]

Acácia: Por isso que eu não tenho cabeça boa para aprender a ler, sabe? Mas para trabalhar, eu trabalhei muito, trabalhei que nem uma condenada.

Lulu: Eu trabalhei até hoje. (CIDADE DE EMAÚS, grifo nosso)

O contexto social e afetivo, ao qual se refere Souza (2009), não é apresentado ou levantado como possibilidade para o fracasso na escola de uma das entrevistadas (Acácia). Ao contrário, ela é bastante enfática ao dizer que “é ruim” em Matemática e em Português. A responsabilidade, segundo a participante, é dela, que não tem “cabeça boa”. No entanto, orgulha-se de dizer que serve para trabalhar. Como diria Souza (2009), a opacidade do contexto social e afetivo da ralé estimula a ilusão da ausência de dominação. Nesse sentido, Souza argumentaria que é forte a presença nos grupos de um discurso autolegitimador para justificar a vida que cada um leva e também dar elementos que atribuam valor a sua existência, "algo para continuar vivendo" (SOUZA, 2009), nem que seja ter parado de estudar na segunda série do ensino fundamental e saber mais de matemática do que alguém da quinta série, como afirma Lulu.

No entanto, não consideramos que o fato de Lulu, por exemplo, orgulhar-se por ser boa aluna em matemática é apenas um subterfúgio para lidar com um “desvalor social objetivo” (CARNEIRO; ROCHA, 2009; SOUZA, 2009) do qual seria vítima. Inspiradas por Brites (2000, 2003) e Biroli (2012), poderíamos entender o exemplo de outro modo: como uma forma de ressaltar alguma capacidade de agência ainda que num contexto em que predominam fortes desigualdades sociais, exploração no trabalho e ineficiência no sistema educacional. Assim, orgulhar-se de ser "boa” em matemática, uma disciplina temida por muitos alunos, mostra como ela é capaz de realizar feitos dignos de valor.

As participantes sindicalizadas apresentaram o TID como prejudicial à educação:

Moderadora: E me digam uma coisa, como foi essa saída de vocês de casa para trabalharem em casa de família? Vocês lembram?

Nete: Necessidade. 
Fofa: Falou certo. Necessidade. Eu morava no interior, em Quatipuru [PA], e como a mamãe não tinha condições e papai de sustentar a gente lá. Aí um colega do meu pai que trabalhava com ele na terra nessa época, ele foi lá em casa e viu a gente toda mocinha e ele pediu, que uma senhora aqui em Belém estava precisando de uma pessoa para trabalhar, para tomar conta dos filhos dela. Aí mamãe já me mandou para cá. Aí já começou por aí. A mamãe já me mandou para tomar conta dessas crianças aqui em Belém. Que foi quando eu vim e já não voltei mais e fiquei trabalhando até hoje aqui em Belém. Não voltei mais para Quatipuru.

Moderadora: E com vocês?

Lenyta: Comigo foi para estudar. Meus pais separaram e ficou só a minha mãe, minha mãe cuidando da família. Então, a minha mãe me botou em casa de família para ajudar nas despesas, para eu poder estudar. E eu fiquei até hoje.

Ericka: $\mathrm{E}$ a gente não tem direito de estudar também, não é?

Rose: [...] Eu não quero me orgulhar, não quero que Deus me castigue, mas jamais também, é uma coisa que eu não quero mais, sabe? Já tenho oito anos da minha carteira assinada, não pretendo trabalhar mais em casa de família, porque, como ela falou, é um serviço que não é reconhecido. Por mais que a gente faça tudo certinho, mas nunca é reconhecido e os nossos direitos também, porque a gente sai com uma mão na frente e a outra atrás. Não tem direito a seguro, não tem direito a décimo, não tem direito a nada. Aqueles que ainda pagam, é ótimo, e os que não pagam? Que tem uns que dizem que não têm direito e é um serviço muito humilhante. Então, eu passei dos meus oito até os meus vinte e três anos trabalhando em casa de família e eu não quero isso mais para mim, tanto é que eu não tive oportunidade para estudar, vim estudar depois que eu já tive meu filho. Meu filho já estava com dez anos quando eu comecei a estudar, só que aí vêm os problemas e veio um atrás do outro também, não é? E esse ano eu ia recomeçar, aí já não deu, aí chegou a neta [...]. E o meu sonho é me formar em enfermagem, que eu já fiz só o básico, não é? E eu quero terminar meus estudos para mim concluir o resto.

Moderadora: E a tua história, Nete?

Nete: A minha história o meu pai abandonou a minha mãe eu tinha sete anos de idade. Eu fui obrigada a passar uns dias na casa da minha avó e depois da casa da minha avó eu fui trabalhar em casa de família tomando conta de dois idosos. Lavava, cozinhava com uma senhora lá me auxiliando. Não saia para nada. Ficava só por ali mesmo. Tinha que dar o remédio no horário certo.

Moderadora: Até que idade?

Nete: Até uns quatorze anos. E aí eu terminei, tanto é que eu terminei o ensino médio agora em 2009. E com a idade que eu estou agora de cinquenta e um 
anos, a situação é precária para arrumar emprego em algum lugar por aí. Só mesmo em casa de família que ainda aceita, mas assim mesmo é o maior obstáculo. (SINDICATO I)

Embora elas relatem que um dos principais motivos para a inserção delas no trabalho doméstico fosse o acesso à educação, o que as participantes desse grupo focal apresentaram principalmente foram as dificuldades que sofreram para conseguir terminar os estudos e que, em geral, fizeram-no (ou, pelo menos, retornaram às aulas) quando adultas porque o trabalho que realizavam em casas de família e a necessidade de estar sempre disponível ("Não saía para nada, ficava só por ali mesmo, tinha que dar o remédio no horário certo") não lhes permitiu antes. De modo distinto da discussão que ocorreu no grupo "condomínio", apresentada anteriormente, na do grupo do "sindicato", os prejuízos do TID para a educação são tematizados.

As participantes Rose e Nete demonstram ressentimento por terem se prejudicado nos estudos, o que restringiu significativamente o caminho profissional que poderiam seguir. Nete conseguiu concluir o ensino médio com 49 anos e lamenta ter como única opção de trabalho as casas de família. No entanto, mesmo para esse tipo de atividade, o caminho é tortuoso, já que empregadas domésticas com mais de 50 não são bem aceitas porque se acredita que elas não têm condições de dar conta satisfatoriamente do serviço.

Apesar de criticarem o trabalho doméstico e suas condições, essas mulheres entrevistadas haviam procurado o Sindicato porque estavam desempregadas, e lá eram oferecidos cursos que aprimoravam as habilidades domésticas, dentre outras. Ainda assim, a maior parte dessas participantes estava desempregada. Portanto, se por um lado havia um discurso crítico a respeito do TID e do trabalho doméstico em geral, por outro, viam nele praticamente a única forma de serem contratadas e de receberem salário.

Das seis entrevistadas sindicalizadas, uma se declarou dona de casa, outra diarista e quatro desempregadas. O discurso sobre os prejuízos ocasionados em razão dos empecilhos que o trabalho gerou para a formação escolar dessas mulheres é respaldado pela situação concreta delas quando adultas. Sem escolaridade adequada e com idade "avançada”, a única esperança que a maioria tinha de voltar ao trabalho era em casas de família, mesmo com todas as críticas e ponderações que elas eram capazes de fazer. 
No grupo das adolescentes atendidas pelo projeto social, elas comentaram conversas com colegas de sala bem mais velhas que estavam tentando estudar após uma vida inteira de trabalho:

Moderadora: E o estudo? Vocês estão conseguindo estudar?

Alicinha: Eu estou!

Erizinha: Eu estou muito bem.

Michelle: Antigamente, quando eu trabalhava, eu não conseguia vir para a aula, não. Cansava muito. Eu ficava muito cansada. Quando eu era menor, sétima e oitava eu fiquei muito atrasada, porque eu ficava mudando de colégio, e eu parava de estudar, agora não...

Alicinha: Batia aquela preguiça e tudo mais, mas lá vai.

Lecka: Olha, eu vou falar uma coisa, a gente estuda, a gente brinca depois que passa o tempo. Depois que passa o tempo é que a gente vai refletir o tempo que a gente perdeu. Tempo não, anos. Porque é um ano inteiro estudando. Depois que a gente reflete...

Michelle: Tem muitas senhoras estudando à noite, sabe? Aí elas falam: 'Ah! Porque quando eu era menor não tinha tempo e agora não terminei os meus estudos e eu estou aqui na escola'.

Lecka: Tem uma senhora que sempre diz assim para mim, a Dona Olinda: 'olha, estuda porque se eu estou hoje aqui não é porque eu quero, é porque eu trabalhei muito e não tive tempo para estudo, mas, estuda enquanto você está nova, estuda'.

Moderadora: Vocês acreditam nisso mesmo?

Alicinha: Acredito.

Erizinha: Com certeza. (PROJETO SOCIAL)

Apesar de considerarem o estudo importante, as adolescentes relatam dificuldades como o cansaço por conta do trabalho e a preguiça. Essa situação, como dissemos anteriormente, é comum no caso do TID que, normalmente, exige da criança e do adolescente uma longa jornada de trabalho e, com isso, por mais que frequentem a escola, é grande a dificuldade de atenção e de aprendizado. Elas se referem de modo crítico aos prejuízos do trabalho infantil e recorrem a exemplos de colegas de classe já adultas para embasar a reflexão sobre a importância da educação.

Uma das adolescentes destaca que, às vezes, a pessoa só se dá conta das oportunidades depois que elas passam. Ainda que as adolescentes recorram, 
de certa forma, ao problema do ponto de vista individual (sensação de cansaço e preguiça), elas extrapolam essa discussão e estimulam uma reflexão sobre o futuro implicado no hoje, o que vai além do foco nas necessidades primárias e desafia a perspectiva de Souza (2009), segundo a qual os sujeitos da ralé preocupam-se com satisfação das demandas imediatas, enquanto os de classe média atuam a partir de planos em médio e longo prazo. Nesse sentido, a referência à capacidade de criticar a situação em que vivem e/ou viviam revela um lampejo de expressão de poder como power to, entendido como "poder de agir apesar da sua subordinação”. (ALLEN, 1998, p. 35, tradução nossa)

Em relação a exemplos de resistência a situações de exploração no TID que repercutiam na educação, observamos que, de modo geral, as mulheres adultas entrevistadas pouco puderam fazer enquanto eram adolescentes para garantir a continuidade dos estudos. Carol, do grupo das jovens adultas entrevistadas na casa de uma patroa, relata que a primeira patroa exigia que ela fizesse de tudo na casa e a obrigou a cursar supletivo do ensino fundamental, mesmo a adolescente já tendo feito a oitava série, porque era no período noturno e, assim, a menina poderiam trabalhar durante todo o dia para estudar à noite, atendendo aos interesses da patroa. A explicação sobre esse caso emergiu durante a discussão sobre o que elas pensavam acerca do TID:

Moderadora: O que vocês pensam sobre isso [trabalho infantil doméstico]?

Carol: Para criança não é muito bom, não é? [...] No meu caso, a pessoa pediu se eu, a minha mãe, tinha alguém para vir [a Belém]. Então, às vezes os pais confiam na pessoa e acredita na palavra da pessoa que ela vai tratar bem o seu filho e às vezes não acontece. No meu caso não aconteceu isso, não é? No primeiro ano foi tudo bem, mas depois ela realmente explorou para eu fazer tudo na casa e coisas que eu nem sabia fazer.

Moderadora: Que coisas?

Carol: Ah! Ela mandava eu fazer tudo em casa. No caso, na casa, morava eu e o marido dela e ela tinha escola. Eu tinha de lavar, passar, cozinhar sem saber e ainda ajudar na escola. Limpar toda a casa. A casa era uma escola, tinha de limpar toda a escola quando todo mundo saía, ainda ajudava na escola. Então ela me explorava e depois o que aconteceu? Ela... Estudava... Depois, no outro ano, eu não conhecia nada de Belém, não conhecia nada mesmo, me mandou me matricular sozinha. Eu fui. Ela me mandou estudar à noite, fazer supletivo, eu já tinha concluído a oitava serie, eu tive de refazer de novo, porque não tinha a série que 
eu tinha de fazer, a oitava serie não tinha à noite, só tinha à tarde. O que eu tive de fazer. Eu tive de matricular e correr atrás, porque ela não, não deixou eu estudar, porque ela falou: 'não, você tem de ficar aqui para me ajudar' e eu não queria parar de estudar e não tinha pra quem eu correr, porque eu não conhecia nada em Belém, eu não tinha o telefone de ninguém. Eu tive de estar submissa a ela, ao que ela queria, você entendeu? Tudo o que tinha... Aí eu passei uma luta até eu conseguir encontrar um telefone do meu irmão, que ele morava aqui. Foi ele que foi me buscar lá, porque eu praticamente, eu quase, eu só... Eu quase assim... O marido dela quase me agredia. Nessa época eu tinha 16 anos, só que ela não acreditou, foi uma confusão na casa lá. É difícil! Tem casas que é muito difícil, porque, assim, eles querem explorar a pessoa, entendeu? [...]

Carol: Isso que eles... eles chamam a pessoa, não é? Quando chega, no primeiro momento está tudo bem, não é? Tudo legal, mas depois que eles mudam, começam a mostrar quem realmente eles são e vão tratar a pessoa totalmente diferente, maltratar, escravizar a pessoa.

Moderadora: E vocês concordam com essa ideia de relacionar o com o trabalho escravo?

Nanã: Eu concordo, porque muitas meninas que poderiam estar estudando, não é? Estão ali fazendo um serviço que uma pessoa maior poderia fazer. No tipo que... Quando eu tinha treze anos, eu pegava bacias e mais bacias de roupas e ia para o tanque lavar na mão. Às vezes, quando eu terminava de lavar roupa, as minhas costas estavam doendo horrores e assim as minhas mãos ficavam todas feridas de tanto esfregar calça jeans na mão e depois colocava no sol. Aí, quando era à noite, eu ficava até onze, meia noite passando roupa. Depois, de manhã, eu tinha muito cedo eu tinha que estar de pé para fazer o café, para levar a criança na escola, fazer aquilo e fazer aquilo outro. Na verdade, se os meus pais tivessem condições, eu poderia estar em uma sala de aula estudando para eu ser alguém mais lá na frente, talvez, é... Eu parei na oitava serie. Não tenho ensino médio completo. Também foi descuido meu, mas também devido a isso, porque muitas casas que eu arrumei emprego não aceitavam para eu estudar. Então parei muito cedo de estudar, mas eu ainda pretendo um dia voltar a estudar, e quem sabe fazer uns cursos e sair da casa de família. (CASA DA PATROA, grifo nosso)

Ainda que em uma situação extremante adversa, sem apoio da patroa e com uma cansativa rotina de trabalho, a então adolescente "correu atrás" e se matriculou na escola. Mesmo tendo que repetir a oitava série, já que precisou entrar 
na turma do Supletivo do Ensino Fundamental para estudar no horário negociável pela patroa. $O$ fato de se manter na escola em meio a uma situação tão desfavorável para que isso ocorresse demonstra, a nosso ver, uma forma de resistência à subordinação imposta pela patroa.

O relato de Nanã, ao contrário, reforça a sujeição da trabalhadora infantil doméstica às exigências dos patrões que não concordavam que ela estudasse. Ela compartilha a culpa com eles ao mencionar que também foi "descuido" dela, porém reconhece que as atividades que exercia eram árduas e cansativas e, por essa razão, considera que há certa incompatibilidade entre educação e TID. Assim, a participante apresenta os prejuízos do TID como concernentes a uma coletividade (“muitas meninas que poderiam estar estudando, não é?").

No grupo das adolescentes que não são ligadas a projetos sociais, houve divergência sobre se o TID poderia ser um “bom trabalho”. Algumas meninas haviam dito que a idade mínima para inserção em empregos deveria variar entre 14 a 17 anos.

Moderadora: Pra quem acha que pode começar a trabalhar com 14, 16, 17, vocês acham que pode ser qualquer trabalho?

Participantes falam juntas: Não.

Moderadora: Não? E qual é o trabalho?

Nati: Um trabalho digno e honesto;

Moderadora: E o quê que é um trabalho digno e honesto?

Nati: Um trabalho com carteira assinada.

Tatá: É.

Nati: Amparado por lei.

Lorrane: Mas [...] A gente tá querendo benefícios também.

Moderadora: Me dêem exemplos.

Nati: Um trabalho que sirva pro nosso futuro, que vá ajudar a gente, que vá fazer com que a gente tenha uma experiência profissional. [...] Um adolescente pode trabalhar também, só que não vai ser aquele trabalho pesado, que ele vai ficar cansado, que não vai dar conta de estudar, que não vai prejudicar as notas dele na escola. Isso que é um bom trabalho.

Moderadora: E vocês, o que vocês acham? Vocês acham que o trabalho infantil doméstico pode ser? O trabalho doméstico?

Nati: Não.

Tatá: Pô... Não. 
Ana: Não.

Moderadora: [...] Mudou de ideia? Por que não?

Tatá: Porque eu acho que é muito [...].

Nati: E é um trabalho que expõe o adolescente. Todo mundo sabe que essas meninas que vão trabalhar em casas de família, algumas são, podem, são abusadas [...], então se expõe o adolescente. Porque nunca se sabe quando tem um patrão bom. [...]

Ana: Tanto a menina quanto a mulher também.

Moderadora: O que tu ias falar sobre o trabalho doméstico? Tu achas que é um trabalho viável para o adolescente assim?

Drika: Viável não é. Mas, assim, sei lá. Deixa eu ver. Porque, assim, eu, eu tô, desde que eu to fazendo [...] eu tô tentando arranjar um [...]. E até agora eu não consegui. Se alguém quiser oferecer uma oportunidade de eu vim trabalhar em casa doméstica, eu toparia.

Moderadora: $\mathrm{Tu}$ terias alguma condição, assim?

Drika: Como assim?

Moderadora: Condição, assim, tu toparias, mas a pessoa teria que fazer alguma coisa, teria que ter alguma garantia, assim, o quê que tu ias pedir, assim, em troca?

Drika: Ia. Dinheiro. Assim, dinheiro.

Moderadora: Mas como é que tua ias saber se é um bom patrão ou não?

Drika: Ah, sim, se eu conhecesse já ele, porque eu não ia. Se aparecer qualquer um assim, um estranho, [...], eu dizia não. Eu tenho que conhecer essa pessoa. (CENTRO DE FORMAÇÃO, grifo nosso)

A concepção de "bom trabalho" apresentada pela Nati procura se distanciar de duas formas de trabalho infantil bastante comuns na realidade em que vive: o TID e a prostituição. Assim, o primeiro é visto como pouco digno na medida em que não "é amparado por lei” nos termos da adolescente. Por mais que exista legislação específica sobre o emprego doméstico, a experiência que elas têm indica que esse tipo de trabalho não respeita dos direitos das empregadas. O segundo é considerado desonesto porque a inserção na prostituição é entendida do ponto de vista individual: meninas que buscaram esse caminho abstiveram-se do "trabalho pesado" para investir em outras formas buscar sustento. Uma forma condenável segundo elas. Essa percepção acerca da "escolha” pela prostituição é compartilhada pelas entrevistadas dos outros grupos (ver, por exemplo, a p. 209 deste livro). 
Embora haja essa discussão do grupo do "centro de formação" acerca da necessidade de adolescentes estarem envolvidos com trabalhos vistos como "dignos e honestos" para que possam continuar estudando, o que propiciará formação profissional, e do TID ser entendido como uma maneira de deixar a menina exposta à violência sexual, uma das adolescentes do grupo se manifestou dizendo que estava desempregada e disponível para uma vaga de doméstica, caso surgisse uma oportunidade.

A partir dessa discussão, percebemos uma intricada e peculiar relação entre o poder como dominação e como empoderamento. Ao mesmo tempo em que algumas adolescentes ressaltam os prejuízos que o trabalho doméstico gera para a educação e formação profissional, dessa maneira, questionando concepções naturalizadas segundo as quais o TID é uma forma de ter acesso à educação, outra adolescente afirma a disponibilidade para se sujeitar a esse tipo de situação.

Enquanto, para as adolescentes, a temática TID e educação se volta para o futuro, o foco das mulheres mais velhas se volta para o sentimento de perdas no passado. Pelo que já viveram, é consensual no grupo do Sindicato, por exemplo, o discurso do estudo como oportunidade de vencer na vida. Apesar de vislumbrarem, de certa forma, um futuro, como fazer o Exame Nacional do Ensino Médio (ENEM) ou voltar a estudar, ou mesmo concluir o ensino fundamental, as condições atuais em que vivem as distanciam dessas possibilidades, de tal modo que as expectativas em relação à educação são transferidas para os filhos, que as decepcionam quando não aproveitam as chances que tiveram. Ana, do grupo "sindicato", conseguiu concluir o ensino médio e estava feliz por poder realizar o ENEM no ano da entrevista, porém estava desempregada e, apesar da idade (57 anos), não tinha renda e morava sozinha. Ao ser questionada sobre como estava conseguindo dar conta de suas despesas, ela informou que fazia alguns poucos serviços como diarista.

Embora tenham muitas críticas ao TID, as mulheres ligadas ao Sindicato não concordam que haja um ciclo de pobreza alimentado pela inserção precoce de meninas nos serviços domésticos e reafirmam a ideia de que é possível vencer na vida por meio da educação e que é possível sair da condição de trabalhadora infantil doméstica:

Rose: [...] Até os meus dezessete anos, eu não sabia nada, mal eu aprendi a assinar meu nome, não é? Às vezes eu pegava o jornal eu queria ler, eu ficava aborrecida 
comigo mesma. Eu chorava porque eu pegava o jornal, eu via aquelas letras ali, mas eu não sabia o que estava escrito. Aquilo para mim era revoltante, humilhante. Aí eu dizia para ela [patroa]: 'dona Maria, a senhora que é professora, dá para a senhora me ensinar?', quer dizer... ela dizia: 'tá, no domingo eu te ensino'. Quer dizer, quando chegava no domingo, pelo fato dela sair de segunda a sexta, às vezes no sábado ela ia dar aula particular, ela não tinha tempo, não é? Como que eu ia aprender alguma coisa? Como eu falei naquele dia, não é? Eu já vim para o colégio depois que eu tive o meu primeiro filho. É depois que eu deixava ele com o pai dele que eu vim para o colégio. Hoje em dia eu não terminei, porque aí veio os problemas também, mas, para o ano, se Deus quiser eu pretendo terminar, não é? E foi quando eu tirei o meu primeiro ano, foi quando eu comecei a trabalhar em firma, quer dizer que aquilo ali para mim foi uma gratificação muito grande, por eu ter conseguido me livrar da casa de família. Hoje em dia eu não quero! Eu digo para essa daqui [nora, que estava presente com a filha na mesma sala], se for para eu ir só por causa de um salário, não ter direito a nada, eu prefiro comer ovo com feijão que tem dentro de casa.

Moderadora: Quem é doméstica faz isso toda vida?

Rose: Não. Só se ela quiser, porque se ela botar na cabeça, hoje em dia tem muitas casas que você já não fica diretamente, vai e volta. Então aí eu acho que é um meio de você se ingressar no estudo, não é? Olha, a sobrinha do meu marido, ela mora com uma senhora há muito tempo. Hoje em dia ela faz faculdade. Hoje em dia o serviço doméstico é humilhante? É, mas só se você não se impor, entendeu? Eu quero estudar, eu só fico se der para estudar. Hoje em dia ela já fez dois vestibulares, passou, ela está fazendo agora a faculdade dela. Vai se formar agora no final do ano. Então a pessoa não deve se prender só ao serviço doméstico. Se ela botar na mente que é aquilo que ela quer ela consegue.

Ericka: Verdade.

Zezé: [...] Que nem a Rose falou, você só fica naquilo se você quiser. Por exemplo: não vai longe. A doutora Lucineide (presidente do Sindicato). Ela era trabalhadora doméstica. Hoje ela está fazendo mestrado. É uma advogada. E muitas outras nós podemos voltar a estudar e se formar e mostrar que nós temos capacidade. Não é só porque você é trabalhadora doméstica que você não tem condição, basta você querer e lutar.

Erika: É a professora Antônia ela também foi empregada doméstica, não é?

Zezé: Exatamente.

[Silêncio]

Ericka: Basta querer. 
Zezé: Não e fácil. Mas você consegue.

Ericka: Consegue. (SINDICATO II, grifo nosso)

Embora trabalhasse na casa de uma professora e solicitasse recorrentemente que ela a ajudasse a aprender a ler, Rose afirmou só ter frequentado a escola depois do nascimento do seu primeiro filho, já no final da adolescência. A então menina se sentia humilhada por não conseguir ler "as letras do jornal”. Sua antiga patroa afirmou que poderia ensiná-la, no entanto, não abriu nenhum espaço na rotina para se dedicar ao aprendizado de Rose. Aquilo que era uma necessidade imediata para a adolescente foi considerado adiável pela patroa.

Rose sujeitou-se a essa condição colocada pela patroa até se casar. Depois, o marido pode ficar com a criança para que ela começasse a estudar. Após cursar o primeiro ano do ensino médio, Rose conseguiu trabalho em uma empresa, o que foi comemorado como uma grande vitória, pois assim ela pode "se livrar da casa de família”. A função na empresa era de limpeza, de serviços gerais. A principal distinção, portanto, não era pelo tipo de serviço que ela realizava, mas sim pelo tipo de relação que é estabelecida quando se trabalha "na casa dos outros" ou em uma empresa, porque essa última garante mais direitos do que a primeira e também há uma distinção clara dessa relação como um emprego, como uma relação trabalhista, e não como ajuda mútua baseada na ambiguidade entre ser cuidada por uma família e ser a menina doméstica, como ocorreu com Rose, que começou no serviço doméstico ao ficar órfã.

As entrevistadas concordam que, se a adolescente quiser, ela pode conseguir sair do TID e entrar em outro ramo profissional por meio da inserção nos estudos, já que, segundo elas, boa parte dos trabalhos de doméstica hoje são para passar o dia. Elas avaliam também que a menina precisa colocar suas condições claramente aos patrões: "Hoje em dia o serviço doméstico é humilhante? É, mas só se você não se impor, entendeu? Eu quero estudar eu só fico se der para estudar”, disse Rose. Exemplos de pessoas que conseguiram entrar na faculdade após trabalharem como domésticas alimentam ainda a esperança e a fé na possibilidade de transformação por meio do aprendizado escolar. Nesse sentido, há uma articulação entre os planos individual e coletivo: "E muitas outras nós podemos voltar a estudar e se formar e mostrar que nós temos capacidade. Não é só porque você é trabalhadora doméstica que você não tem condição. Basta você querer e lutar”. Pela primeira vez, o discurso acerca do TID é apresentado nos 
termos de algo concernente a um grupo ("nós”). Embora o problema seja colocado dessa forma, o modo de ação considerado é ainda individualizado: "basta você querer e lutar”.

Entretanto, a expressão "basta querer" torna apagada toda a dimensão mais estrutural que envolve o TID e as reais condições que meninas e adolescentes afetadas têm de transformar suas próprias vidas, porque restringe as possibilidades de mudança de vida à vontade individual. De acordo com Souza (2009), a percepção da "culpa" pelo sucesso ou pelo fracasso como individual desvia a atenção da discussão sobre as graves desigualdades sociais vividas em nosso país, ou, de modo mais perverso, faz com que elas sejam consideradas justas "porque decorrentes do esforço e desempenho diferencial do indivíduo”. (SOUZA, 2009, p. 43) Nesse caso, todavia, a aposta na capacidade do grupo ("nós podemos”) significa também o depósito de confiança na possibilidade de conseguirem, por si próprias, mudar de vida, apesar das grandes desigualdades nas quais estão envoltas. Nesse sentido, inspiradas por Biroli (2012), consideramos adequado fazer referência aos modos de agência dessas meninas e mulheres como uma agência tentativa, no sentido de que advém das experiências delas próprias em tensionar (e reagir a) estruturas opressivas.

Tensões entre as perspectivas dos media e das afetadas sobre violência e educação

Essa temática "violência" foi abordada de modo aleatório e fragmentado nos jornais analisados. Meninas envolvidas com atividades domésticas foram trazidas a público de modo pontual, porém poucas foram as matérias que discutiram analiticamente elementos do TID. As dimensões de dominação presentes no TID tiveram atenção privilegiada, o que, por sua vez, repercutiu no posicionamento habitual das meninas domésticas como vítimas por excelência, sujeitos frágeis e resignados, suscetíveis aos atos violentos em razão da sujeição aos patrões.

Em uma das matérias, uma promotora de justiça afirmou até admitir o TID para poder fiscalizá-lo e evitar violência sexual. Ainda que as meninas envolvidas no TID tenham tido preponderantemente um lugar de fala como vítimas, houve ainda, na cobertura dos jornais analisados, um exemplo de posicionamento resistente, em que, apesar de a menina ter sofrido severas punições impostas pelo método "educativo" da patroa, ela conseguiu construir um plano para o futuro e 
apresentou o desejo de se tornar delegada, informação essa tratada com importância pelo jornal, que a colocou no título da matéria.

Nos grupos focais, a temática da violência pôs em destaque relações de power over que puderam ser percebidas a partir de constatações como as das adolescentes do Centro de Formação, que entendiam serem limitadas as possibilidades de ação e de resistência das meninas domésticas ("a adolescente não pode fazer nada"). As adolescentes do "projeto social" e as senhoras da "cidade de Emaús”, por sua vez, reforçaram a vitimização da menina doméstica em razão da dificuldade de sua fala ser considerada tanto pela família empregadora quanto pela família de origem, o que não somente estimula a violência - porque são vistas como "sujeitos sem voz" - como também alimenta a impunidade. O que essas meninas dizem não é levando em conta, ou então é enquadrado como mentira. A inferioridade da trabalhadora infantil doméstica é marcada também pela impossibilidade de ser admitida como objeto de desejo do filho do patrão, por ser negra e por ser a empregada, o que faz com que o estupro seja negado, já que não havia como um filho do patrão se interessar por aquela. ${ }^{15}$

Mesmo sob ameaças ou medo de punições mais severas, algumas das mulheres entrevistadas marcaram um espaço de resistência a situações de violência no TID com gestos como, por exemplo, decidir não voltar para a família empregadora embora tivessem que enfrentar em casa um pai opressor, ou sair da casa de família mesmo com pedidos de perdão do patrão e sem ter para onde ir, ou ainda dizer não ao pedido de casamento feito pelo ex-patrão estuprador. E algumas partem dessas experiências para demonstrar injustiças relacionadas ao TID e a indignação frente à ideia de que a menina deve se sujeitar a todo tipo de ordem dos patrões, e outras, como é o caso de Zezé e Lenyta, as transformam em motivação para luta coletiva.

15 Essa mesma lógica perversa estimula discursos como o de que não se deveria confiar na qualidade profissional das médicas cubanas por terem "cara de empregada doméstica". O contexto desse discurso é a chegada de médicos cubanos no Brasil por meio do Programa Mais Médicos, do Governo Federal. Entre discussões acirradas acerca da capacidade técnica deles em atender bem os brasileiros, uma jornalista publicou em uma rede social online o seguinte comentário: "Me perdoem se for preconceito, mas essas médicas cubanas tem uma Cara de empregada doméstica. Será que São médicas Mesmo? Afe que terrível. Médico, geralmente, tem postura, tem cara de médico, se impõe a partir da aparência... Coitada da nossa população. Será que eles entendem de dengue? Febre amarela? Deus proteja O nosso povo!" (Comentário em perfil do facebook, postado em 27/08/2013 e bastante repercutido nas redes sociais online e nos media). 
Em síntese, a temática da educação foi abordada pelos jornais destacando violações desse direito que o TID provoca. Haveria, então, uma incompatibilidade entre a educação regular e esse tipo de trabalho infantil em razão do cansaço provocado pelas longas jornadas e serviços exaustivos. Nesse sentido, as vozes das afetadas foram posicionadas, sobretudo, como vítimas em razão do déficit escolar e também por se sujeitarem a impedimentos impostos pelos patrões para que elas não estudassem.

Por meio da recorrência a especialistas e atores sociais, o discurso dos media adensa esse processo de vitimização para englobar também o Estado como opressor, na medida em que ressalta as deficiências do sistema educacional brasileiro, já que as escolas não possuem condições concretas de manter crianças e adolescentes interessados e aprendendo com qualidade. Mesmo os programas assistenciais de transferência de renda são apontados por atores sociais como ineficazes no combate ao trabalho infantil por acompanharem apenas a frequência à unidade de ensino, e não o processo educativo. Assim, as relações de dominação implicadas no TID em interface com a educação dadas a ver pelos jornais posicionam as trabalhadoras infantis domésticas como vítimas tanto desse tipo de trabalho infantil quanto da ineficiência do Estado.

Entretanto, há uma distinção crucial estabelecida pelo discurso dos jornais entre o modo com foram tematizadas a história de personagens ligadas e não ligadas ao Petid. Por um lado, embora a educação seja apontada como um caminho para buscar melhores de vida pelas adolescentes ouvidas, as falas indicavam que, quando adolescentes sem vínculo com projetos sociais afirmavam o desejo de retomar aos estudos e mudar de condição, esse projeto era considerado com certa descrença. Por outro lado, quando a adolescente que expressava esse desejo estava vinculada ao Petid, o discurso era de mudança e de transformação em razão das ações de retaguarda e proteção. Assim, essas eram posicionadas de maneira resistente à condição de trabalhadoras infantis domésticas.

Merece destaque também a resistência ao enquadramento oferecido pelo jornal expressa na fala de uma jovem que havia sido beneficiada pelo Petid no início do projeto, mas já se encontrava em outra situação. Ela fez questão de evidenciar que não se deixou sujeitar pelo TID, que não era mais integrante do Programa e que ministrava oficinas por vontade de atuar em um projeto social. A jovem também marca constantemente no seu discurso a distância entre ela e elas (as meninas atendidas pelo Programa). 
Nos grupos focais, a temática da educação desvelou diferentes matizes de relações de power over. Frente a situações extremamente desfavoráveis do aprendizado escolar nos municípios de origem, as mulheres que vieram do interior do Pará e do Maranhão apontaram como uma das justificativas para ingresso no TID a esperança de usufruir de condições educacionais melhores. Mesmo apresentando problemas relacionados ao TID ao longo de outras temáticas, no caso da educação, para as mulheres do condomínio, por exemplo, foi o trabalho que propiciou o estudo de fato, seja pela atenção dispensa pela patroa, seja porque no TID as atividades eram vistas como menos penosas do que na roça. No entanto, as entrevistadas se consideram, em geral, culpadas pelo fracasso escolar porque não teriam se dedicado o suficiente. O discurso da igualdade de oportunidades atribuído a uma das patroas reforça essa percepção.

Ao mesmo tempo, ainda no grupo "condomínio", uma das participantes deixa claro que, se voltasse a estudar, seria apenas para conseguir desconto no transporte público. Nesse sentido, é preciso reconsiderar as observações de Souza sobre o modo como os sujeitos “da ralé" priorizam as necessidades primárias - portanto, pagar mais barato pelo ônibus significaria embolsar metade do valor mensal dado pela patroa para deslocamento da empregada - ao invés de se dedicar a planos de longo prazo. O retorno da educação para melhorias de condições de vida é lento, demorado e pode não ocorrer, considerando a situação das escolas e das políticas desenvolvidas.

Contudo, essa perspectiva não é majoritária entre as meninas e mulheres ouvidas. Elas também ressaltaram, principalmente as adolescentes, as jovens adultas e as sindicalizadas, os prejuízos que o TID pode provocar à educação formal e apontam o estudo como uma promessa que não é concretizada quando as meninas começam realmente a trabalhar em casa de família. As mulheres do Sindicato reafirmaram a possibilidade de romper com o círculo de pobreza estimulado pelo TID por meio da educação e do reforço à capacidade das trabalhadoras domésticas conseguirem esse objetivo.

\section{PROJEÇÕES DE FUTURO E RESPONSABILIDADES}

Nesta última grande seção de análise, lançamos luz a respeito das relações de poder e a tematização das perspectivas de futuro de meninas e mulheres afetadas 
pelo trabalho infantil nos media e nos grupos focais. Consideramos essa temática pertinente para nosso problema de pesquisa porque possibilita apreendermos o que está em jogo quando se projeta um futuro para elas e a partir delas. De modo correlato, discutir como são atribuídas responsabilidades pelo TID nos permitirá completar o quadro analítico por meio do qual examinaremos como relações de poder participam da configuração política desse tipo de trabalho infantil.

\section{Perspectivas de futuro}

A temática "perspectivas de futuro" foi abordada em apenas 14 matérias nos media estudados. Trata-se, portanto, de um assunto pouco tratado na cena pública. Ainda assim, houve dois modos principais pelos quais o futuro foi relacionado ao TID: a) TID como prática que traz prejuízos ao futuro de crianças e adolescentes e b) o Petid proporcionando um futuro a meninas que não o teriam antes dele. O primeiro foi apresentado, sobretudo, a partir da fala de especialistas e atores sociais, representantes do Cedeca-Emaús, do Unicef e da OIT. O segundo decorreu da forma como os media analisados se apropriaram de relatos de meninas ex-trabalhadoras domésticas utilizadas como personagens e os enquadraram na tessitura narrativa dos jornais.

Por meio da tematização do TID como uma violação de direitos da criança, o futuro, apresentado como um desses direitos, também poderia ser prejudicado. Frente a discursos compartilhados socialmente de que poderia ser uma saída para crianças pobres - o qual ganhou contornos específicos, quando discutidos nos grupos focais -, especialistas e representantes de organizações sociais, quando ouvidos, enfatizaram a impossibilidade de que a criança ou adolescente tivesse um futuro profissional promissor a partir da entrada no TID.

'A única oportunidade de futuro que essas meninas que trabalham como domésticas têm, se não tiverem educação e profissionalização, é continuar trabalhando como domésticas', diz Jaques Schwarzstein, coordenador do Unicef para a Amazônia. (O LIBERAL, 16/10/2003)

Assim, a prática do TID é considerada opressiva porque constrange as alternativas de futuro e restringe as conquistas possíveis das crianças e adolescentes que o exercem. Essa perspectiva estava em perfeita consonância com o material 
da primeira campanha de publicidade elaborado pelo Petid (ver capítulo dois), que trazia como principal referência a ideia de que o futuro se constrói em casa, mas com carinho e proteção dos pais, e não com trabalho infantil. Nesse sentido, as falas de atores sociais e especialistas reforçaram no âmbito dos media a incompatibilidade entre a construção de um futuro digno para meninos e meninas e a inserção no TID.

Portanto, combater o TID significava permitir a perseguição de um futuro distinto, em que sonhos pudessem ser realizados. Na retranca "Meninas recuperam direito de sonhar", da mesma matéria citada anteriormente, são contadas as histórias de duas personagens que foram trabalhadoras infantis domésticas e estavam sendo atendidas pelo Petid.

\begin{abstract}
Moradoras do Benguí e colegas de escola, DBB, 15 anos, e LSS, 13, começaram a trabalhar como babás para ajudar as mães, desempregadas e sem ajuda dos pais das meninas. Ambas entraram no Aquarela dos Sonhos [Petid] em maio deste ano, quando uma assistente social visitou a escola. Agora, recebem bolsa-escola, fazem cursos no Cedeca e estão descobrindo no teatro uma forma de ampliar as relações com o outro e alimentar o sonho. DBB está na $7^{\mathrm{a}}$ série e quer ser modelo ou atriz. LSS está na $6^{\mathrm{a}}$ série, adora geografia e estudos amazônicos, odeia matemática e sonha tornar-se advogada: 'A filha da patroa da minha mãe era advogada. Eu achava ela muito bonita. Depois que comecei a fazer os cursos do Cedeca também fiquei pensando em ser advogada para defender os direitos das crianças'. (O LIBERAL, 16/10/2003, grifo nosso)
\end{abstract}

Carneiro e Rocha (2009) discutem a história de vida de Leninha, uma mulher que, desde o início da adolescência, vivia como agregada na casa de uma família burguesa. Eles detalham o quanto que Leninha ressaltava o desejo de ser igual às filhas do casal, frequentar os mesmos lugares, namorar o mesmo tipo de rapaz, gozar do mesmo conforto e das mesmas expectativas acerca da vida. Contudo, os anos vão passando, e ela vai percebendo que a distância entre os possíveis para ela e os para as filhas do casal era intransponível. No caso da adolescente ouvida na matéria, a inserção no Petid contribuiu para que ela se sentisse empoderada e recuperasse a possibilidade de se imaginar como a filha da patroa. Enquanto 
convivia na casa da patroa da mãe, admirava a filha dela, que era advogada, mas havia um fosso muito grande entre as possibilidades concretas da menina e a profissional do direito. A atuação, então, do Cedeca-Emaús permitiu que a adolescente considerasse esse obstáculo passível de ser superado.

Assim, o lugar de fala da adolescente é de alguém que está construindo sonhos, pensando em alternativas de futuro, as quais foram possíveis a partir da ajuda do Cedeca-Emaús. Encontramos vários os exemplos dessa natureza ao longo da cobertura, nos quais são apresentadas como personagens, meninas que saíram do trabalho doméstico por meio do Petid e construíram expectativas sobre mudança das condições de vida.

Soraia, de 17 anos, é uma delas. Na primeira parte da matéria, são relatadas diversas humilhações que a adolescente sofreu desde que começou, aos 11 anos, a trabalhar em casas de família, até entrar para o Petid:

Hoje, consciente e inserida no programa de combate ao TID, Soraia critica as famílias que a empregaram com promessas de ajuda não cumpridas, mais a exploração, mas não culpa a mãe por tê-la entregue ao trabalho. Quer recuperar o tempo perdido e tornar-se [sic] assistente social, profissão que ela já experimenta um pouco no trabalho de organizar outras meninas para discutir os problemas e avançar nas soluções. Também participa de cursos de qualificação, enquanto faz a $8^{\mathrm{a}}$ série do ensino fundamental. (O LIBERAL, 12/02/2004)

Assim, o modo com a ações do Cedeca-Emaús são apresentadas, em comparação à situação anterior de vida das meninas atendidas, posicionam a organização como incentivadora do empoderamento dessas adolescentes, sem capacidade e condições de procurá-lo por si mesmas. Por outro lado, Romano (2002, p. 14) ressalta, como vimos no terceiro capítulo, que o "empoderamento não é algo que pode ser feito a alguém por uma outra pessoa" e que as instituições podem criar um ambiente favorável, mas que esse processo pressupõe uma conquista particular. Assim, ser atendida pelo Petid alimenta a percepção sobre a possibilidade de mudar de vida.

A cobertura dos jornais sobre a temática do futuro posicionou as adolescentes afetadas pelo TID como resistentes à condição de trabalhadora doméstica e, ainda, como sujeitos políticos que participam de ações em prol do enfrenta- 
mento dessa prática. As meninas ouvidas nessas condições eram atendidas pelo Cedeca-Emaús. No limite, podemos dizer que, na arena discursiva dos media, a existência de futuro para meninas envolvidas com o TID estava condicionada à participação no Petid. E que futuro seria esse? Quais as possibilidades concretas de transformação de vida dessas meninas, ainda que inseridas em projetos sociais? Segundo o discurso construído pelos jornais acerca do futuro dessas meninas, a entrada no Petid é a própria garantia de poder tê-lo. Todavia, a tematização desse assunto nos jornais não avança para além do Programa, ou mesmo para problematizar suas ações e a eficácia delas em tornar essa (nova) promessa concreta.

Apesar de toda a crítica que os media endereçam à prática do TID, não há nenhum espaço, nos 10 anos de cobertura analisados, para a discussão sobre as ações do Petid e sobre as consequências na vida de crianças e adolescentes atendidos. ${ }^{16}$ Permanece, assim, uma questão em aberto: mesmo partindo do pressuposto de que a atuação do Petid era a melhor possível para estimular a garantia dos direitos de meninos e meninas beneficiados, a promessa bastante crível de mudança nas condições de vida desses, alimentada pela inserção no Programa, não poderia dar margem para um novo reconhecimento igualmente ideológico? Qual a distância entre as promessas envoltas na condição de beneficiário do Programa e as suas efetivas realizações materiais?

\section{PERSPECTIVAS DE FUTURO A PARTIR DOS GRUPOS FOCAIS}

Investigar o que meninas e mulheres ex-trabalhadoras domésticas vislumbram como futuro nos permite analisar como esses planos são construídos e como elas se posicionam nessa cena projetada. Além de falarem sobre sonhos e perspectivas individuais, a visão de futuro que as entrevistadas desenham inclui vontades relacionadas à prática do TID e das condições de meninas que o realizam. De modo geral, nos grupos com adolescentes e mulheres jovens, a principal expectativa de futuro é a entrada no ensino superior. Elas acreditam que se conseguirem cursar um curso universitário terão melhores oportunidades profissionais,

16 Durante todo o período investigado, apenas quatro ex-beneficiadas pelo Petid foram entrevistadas pelos jornais. Ainda assim, foram meninas que atuaram diretamente como bolsistas do Cedeca e, portanto, tiveram atenção privilegiada. Não há informações na cobertura jornalística sobre a transformação na vida de outras crianças e adolescentes que haviam sido atendidos pelo Programa. 
o que lhes permitirá dar uma vida mais digna aos seus filhos e fazer com que não precisem passar pelo que viveram no TID.

No grupo "centro de formação", uma das meninas afirmou conhecer uma adolescente que havia sido trabalhadora infantil doméstica e que conseguiu fazer faculdade:

Moderadora: E vocês, me digam, assim, o que vocês querem pra vida de vocês?

Tatá: Ou quero ser veterinária ou cientista.

Nati: Eu quero ser ou quero fazer medicina ou psicologia.

Moderadora: E vocês?

Lorrane: Eu quero ser cantora. Eu também quero ser atriz.

Moderadora: $\mathrm{E}$ tu, o quê que tu queres ser?

Drika: Policial.

Moderadora: E tu, Diana, o quê que tu queres ser?

Ana: Não faço ideia.

Moderadora: Nunca pensaste nisso? Sério, tu nunca pensaste nisso? [...] E vocês acham que o trabalho infantil doméstico dá futuro?

Ana: Acho que não.

Moderadora: E vocês, o quê que vocês acham?

Nati: Pra mim, não dá futuro.

Lorrane: Assim, eu conheço uma colega minha que pra ela deu futuro ser trabalhadora doméstica. Porque ela deu muita sorte de ter encontrado um patrão bom. Porque ela trabalha e aí eles deixavam ela estudar, eles pagaram uma faculdade pra ela. Eu sei que ela tá se dando bem. Parece até que ela já viajou para a Europa, parece. [...]

Moderadora: Mas vocês acham que isso acontece muito?

Não.

Nati: É raro. (CENTRO DE FORMAÇÃO, grifo nosso)

Ao serem questionadas sobre o que queriam para a vida, a maioria das meninas entrevistadas prontamente citou profissões aos quais gostariam de ter, porém uma das meninas afirmou que não sabia o que queria e, portanto, não tinha uma resposta. Nesse caso, percebemos na nossa própria fala como moderadora, um juízo de valor sobre o assunto, por mais que nos esforçássemos para não emiti-los durante os grupos, esse momento de interação não é controlável no todo. O fato de indagarmos "Sério, tu nunca pensaste nisso?” marca, de certo 
modo, nosso lugar de fala, de quem cresceu pensando que o futuro estava ligado à definiç̧ão de carreiras universitárias, as quais, desde a escola perseguíamos, embora em vários momentos com dúvidas sobre quais seguir, porém sempre com opções.

Quando a adolescente afirmou nem sequer ter vislumbrado uma carreira, aquilo nos provocou estranheza, pois o entendimento que temos de infância e de adolescência é que são sujeitos em formação e que participam da construção de planos em longo prazo. (FONSECA, 1995) Essa é a nossa perspectiva sobre o futuro. E a delas? Em certa medida, algumas delas compartilham desse imaginário quando apontam carreiras que gostariam de ter. Mesmo quando uma delas afirma que conhece uma menina que "teve futuro" a partir do TID, o que é ressaltado como indício disso é o fato de ela ter cursado o ensino superior. Portanto, ainda nessa perspectiva, o futuro que advém a partir também de acesso a recursos educacionais.

Apesar de indicar um caso bem sucedido de TID, elas apresentam-se cientes de que trata de uma situação bastante incomum. Não percebemos, nesse grupo, nenhum vislumbre com a ideia de que o TID poderia ser o caminho de uma vida melhor, pelo contrário. Quando citado, como no caso da adolescente que estava buscando um trabalho, era para suprir uma necessidade imediata de ter seu próprio dinheiro, mas, ainda assim, não demonstraram se tratar de uma forma de crescer na vida.

Essa mesma percepção foi compartilhada entre as adolescentes do "projeto social":

Moderadora: E quando a patroa é boa, vocês acham que o trabalho doméstico dá futuro?

Michelle: Mesmo assim, não dá futuro. Porque não é isso que a gente quer pra gente. Nós queremos algo mais.

Moderadora: O quê?

Lecka: Queremos um trabalho que seja digno de nós mesmo. Não é isso que vai dar futuro [...]

Erizinha: No caso, correr atrás de nossos sonhos. Que nem a mamãe diz: corre atrás dos teus sonhos.

Michelle: Aí, no caso a pessoa quer ser doutor... Não pensa em ficar ali na cozinha lavando as panelas dos outros. [risos] 
Moderadora: E vocês querem ser o quê?

Erizinha: Quando eu crescer, eu quero ser pediatra.

Entrevistador: $\mathrm{E}$ vocês?

Michelle: Eu quero ser professora de matemática. [risos]

Entrevistador: E vocês?

Lecka: Ah! Eu queria ser uma promotora de justiça.

Alicinha: Eu quero ser juíza, ganha mais! [risos] Melhor do que ser professora... [risos]

Lecka: E tu, Cris?

Michelle: Eu quero ser Cientista.

Erizinha: Eu quero ser pediatra ou veterinária, cuidar de animais

$[\ldots]$

Alicinha: E tu, Cris?

Moderadora: Ainda não pensaram sobre isso, não é Cris? Quando tu te vês daqui a dez anos... tu te imaginas como?

Cris: Não tem que falar antes do tempo, se não pode acontecer errado. Falta muito tempo.

Michelle: Não! Nada a ver.

Erizinha: Pode ser por isso que a gente fala, a gente sonha em ser isso, um dia a gente pode alcançar este sonho e ser isso que a gente quer. (PROJETO SOCIAL)

Para as adolescentes ouvidas, a construção de um futuro melhor se baseia na inserção em um tipo de trabalho considerado mais digno do que o doméstico. Assim como as adolescentes do "centro de formação", a maioria apontou profissões e carreiras que gostariam se seguir por afinidade ou pela remuneração que propiciam. Uma delas, porém, preferiu não falar sobre isso porque o futuro estava distante. $\mathrm{O}$ modo como as outras participantes se posicionaram sobre isso destacou a percepção de que o futuro está implicado no hoje. Portanto, construir sonhos e fazer planos já seriam uma forma de irem construindo esse futuro.

No "projeto social" também não houve nenhuma referência à ideia de que o TID seja uma forma de alcançar esse futuro que elas buscam. Sobre esse assunto, Michelle foi taxativa: "Aí no caso a pessoa quer ser doutor... Não pensa em ficar ali na cozinha lavando as panelas dos outros”. Portanto, há uma dimensão crítica forte no grupo em relação às possibilidades propiciadas pelo TID. Para diminuir a distância entre seus sonhos e a situação na qual vivem hoje, as adolescentes acreditam na importância de estudar e se interessar pela escola para isso. 
De acordo com os dois grupos de adolescentes, pensar no futuro significa afastar-se do TID. A forma como elas discutem o futuro desvela resistência à condição de trabalhadora infantil doméstica porque elas analisam como falsas as promessas de melhorar de vida (embutidas no ideário do TID) e se referem a modos de superação desse lugar, que consideram pouco digno e sujeito a humilhações.

Entre as adultas jovens do grupo "casa da patroa”, houve manifestações de que esse tipo de trabalho infantil poderia "dar futuro", dependendo dos patrões e da adolescente. Essa posição é baseada, sobretudo, na história delas, que vieram da zona rural de municípios do interior com pouca infraestrutura educacional e poucas opções de emprego. Naquela condição, como já discutimos anteriormente, o TID se apresentava como uma alternativa viável para as adolescentes. Contudo, quando imaginam hoje um futuro, elas pensam em ter um curso superior, ter uma casa e uma família:

Moderadora: E para o futuro de vocês, o que vocês imaginam daqui uns cinco anos ou dez anos? [Risos]

Maria: Eu imagino muita coisa.

Moderadora: Como é que vocês vão estar?

Nanã: Eu daqui uns cinco anos eu queria pelo menos ter voltado a estudar, ter uma casa que eu não tenho, não é? E ter a minha família.

Maria: Daqui uns cinco anos eu penso e peço para Deus que me ajude eu estar terminando a minha faculdade para eu ter um emprego melhor e ter a minha família e seguir a vida... [Risos]

Moderadora: E tu Carol?

Carol: Creio que daqui... Em nome de Jesus, não é? Que daqui uns cinco anos eu estarei com a minha família, estarei em um bom emprego... Eu creio não é? Nós temos que profetizar sobre a nossa vida tudo de bom, não é? E poder já voltar para lá ate com filhos, não é? Não sei, mas assim eu quero poder dar tudo para o meu filho aquilo que eu não tive oportunidade

Maria: Nós temos que ter um emprego bom para poder dar...

Moderadora: E o que é um emprego bom?

Maria: Olha, emprego bom, assim sem ter que estar na casa de família e ganhar pelo menos assim um salário a mais de quinhentos e pouco, mil e pouco para poder ter, para eu ajudar meu filho, comprar aquela roupa que eu não tive... 
Moderadora: Ah, entendi então, pode ser então trabalho na casa de família desde que seja um salário maior.

Maria: É, mas assim mesmo daqui uns cinco anos, eu te garanto que se Deus quiser eu já estarei em uma faculdade tentando arrumar um emprego melhor para mim.

Moderadora: Que faculdade?

Maria: Eu pretendo fazer pedagogia.

Nanã: Ô meu Deus... [Risos]

Maria: Para ensinar crianças, eu me identifico muito com criança, eu já trabalhei muito de babá, então... Porque assim eu vejo lá no meu lugar, pessoas assim que não estudaram e que tem essa oportunidade de ensinar crianças... Vão ensinar o quê que se não sabem? [Risos]

Moderadora: E tu Carol, que profissão pretende ter?

Carol: Assim, em um escritório trabalhar com pessoas... eu gosto de pessoas, falar com público...

Moderadora: Mas quer fazer faculdade?

Carol: Pretendo, mas para isso eu preciso conseguir um emprego que eu possa ganhar mais de um salário para poder pagar, não é? Porque com um salário não tem como eu pagar a faculdade se eu conseguir um emprego melhor... (CASA DA PATROA)

Elas reconhecem a dificuldade de conseguirem conquistar os seus sonhos e fazem votos de fé para que eles se concretizem. No entanto, não se trata apenas do que Souza chama de "saídas mágicas", que se referem à crença em mudanças rápidas, "decretos que mudam o mundo com uma penada”. (SOUZA, 2009, p. 431) A nosso ver, as participantes dos grupos focais não se apresentam como sujeitos que estão à espera de saídas mágicas, simplesmente como "presentes caídos do céu”, apesar do forte componente religioso em suas falas. Isso porque sabem do caminho que precisam percorrer para buscar seus sonhos. Carol, por exemplo, afirma precisar de um salário maior para poder pagar a faculdade. Naquele momento da entrevista, ela era a única participante que, além de trabalhar como babá, fazia cursos profissionalizantes na área de informática, o que sinaliza que esse desejo de ter um emprego melhor estava sendo perseguido. O gesto de Carol demonstra o engajamento na consecução dos planos de futuro e desvela uma ação de resistência à condição de trabalhadora doméstica. Predomina, nesse caso, power to como habilidade para questionar e subverter lógicas opressivas. (ALLEN, 1998, 2000) 
Entre as mulheres do Sindicato, a educação também é destacada como principal perspectiva de futuro, sobretudo, quando, após os 50 anos, há poucas oportunidades de trabalho. Para as senhoras do grupo "cidade de Emaús", o olhar que lançam acerca do futuro envolve principalmente os netos, a vontade de que tenham uma vida honesta, melhores condições de trabalho e que não passem as mesmas dificuldades que as avós na infância e na adolescência, vivendo em casas de família.

As entrevistadas que trabalham em condomínio se disseram satisfeitas com a condição atual. Afirmaram que se sentem respeitadas nos seus empregos porque recebem todos os direitos trabalhistas e outros benefícios ainda não regulamentados com o Fundo de Garantia do Tempo de Serviço (FGTS). Trabalham oito horas por dia e ganham hora-extra se precisarem gastar mais tempo no serviço: ${ }^{17}$

Moderadora: E vocês tinham vontade de ter outras profissões quando vocês eram adolescentes?

Tamires: Quando eu era, eu tinha muita vontade de ser uma professora, eu tenho maior vontade de ser professora, mas... [risos].

Wanderléa: Na minha infância eu brincava muito de... O tempinho que eu tinha, a gente brincava... Minha mãe fazia aquelas bonecas de milho, de pau, do que fosse. O pouquinho que a gente brincava eu só gostava de ser médica [risos]. Eu só gostava de ser medica. Tanto que, uma vez, na minha adolescência, essa minha irmã que mora no Rio, eu cavei um buraco no quintal, enterrei ela, deixei passar uns minutinhos e depois descavei para salvar ela, aí eu salvei ela [risos]. Eu me lembro disso até hoje, olha?

Tamires: [risos] Meu Deus que loucura!

Wanderléa: Eu me lembro disso até hoje, olha? Eu cavei um buraco fundo, acho que um buraco assim quase dá uns cinco palmos por aí assim, aonde coubesse ela toda, que fosse cobrir ela toda de areia. Aí coloquei um negócio quase igual esse assim no rosto dela para não cair terra e tacando terra em cima. Aí depois fiquei uns minutinhos. Não era hora. Acho que foi questão de uns três minutos. Aí depois cavei, cavei e salvei ela [risos]. Aí minha mãe foi chegando, aí eu peguei uma surra, não é? [risos]. Peguei uma surra que eu me lembro ate hoje. [...]

Moderadora: Irmão mais novo sofre, não é?

Wanderléa: E ela era caçula. Até hoje ela se lembra, coitada.

17 Como já havíamos informado, na época das entrevistas a PEC 66/2012, conhecida como PEC das Domésticas, ainda não havia sido aprovada. 
Moderadora: E tu Karla? Tu tinhas vontade de ter outra profissão?

Karla: Eu tinha vontade de ser professora, porque eu achava muito bonito naquela época. Professor era muito respeitado na época que agente era pequeno, eu achava uma profissão bonita. Hoje em dia não é mais como era antes, os professores eram praticamente o segundo pais da gente na escola, agora hoje em dia os professores vivem, coitados, vivem ameaçados pelos próprios alunos. [...]

Wanderléa: Pois é. Quer dizer que do meu sonho eu realizei só um pouquinho, aplicar injeção, cuidar de idosos, fazer curativo, fazer isso, fazer aquilo, tirar uma pressão, um pouquinho

Tamires: Mas agora tu não pega o idoso, tu não corta ele [risos].

Wanderléa: Eu não realizei o sonho completo, mas deu para o gasto. (CONDOMÍNIO, grifo nosso)

Apesar de relatarem sonhos de infância, como o de ser professora ou enfermeira, por exemplo, consideram que eles foram parcialmente contemplados, como no caso de Wanderléia, ou deixados de lado, como Karla, que pensava em ser professora, mas não gostaria mais de sê-lo por diagnosticar que esses profissionais não são respeitados pelos alunos. Tamires, contudo, refere-se à vontade de ser professora no tempo verbal presente, porém o uso da expressão adversativa "mas" implica uma contrariedade. Em outro momento do grupo focal, ela informou que "não tinha mais paciência de estudar" (p. 260 deste livro), ou seja, não está mais disposta a correr atrás daquele sonho.

As entrevistadas desse grupo relataram que já estão acostumadas com seus serviços e atribuem a si a responsabilidade por não terem seguido outros caminhos: "nós já nos acomodamos, já nos acostumamos, não fomos atrás de procurar estudar, não é? Para arranjar um serviço, um outro tipo de serviço [...]”, afirmou Rose.

Outro desejo apontado por todas as participantes da totalidade de grupos ouvidos foi de que o trabalho doméstico fosse mais respeitado e que a trabalhadora infantil doméstica fosse protegida da exploração. Apesar de não haver concordância a partir de qual idade a pessoa já pode trabalhar nesse tipo de serviço, todas afirmaram que deve haver condições para que a adolescente doméstica se desenvolva, sobretudo por meio dos estudos, e tenha possibilidade de traçar um caminho profissional distinto. 


\section{Responsabilidade pelo TID}

Problematizar o futuro de crianças e adolescentes que trabalham como domésticas, traz à tona a indagação sobre as responsabilidades pelo TID e também sobre as perspectivas para solucioná-lo. Na cobertura dos media analisados, a temática da responsabilidade pelo TID correspondeu a 14,5\% das ocorrências. Em geral, os textos discutiram principalmente quatro aspectos ligados a esse assunto: a) cultura como instância responsável pelo TID; b) necessidade de união da sociedade e dos empresários contra o TID; c) responsabilidade governamental acerca do problema e, especificamente, d) a necessidade de rever a lógica de programas assistenciais, que "responsabilizam as crianças e não os pais pela sustentabilidade da família” [Pesquisadora Lúcia Garcia]. (DIÁRIO DO PARÁ, 26/07/2002)

Embora os jornais também tenham utilizado como recurso narrativo o reforço ao posicionamento de adolescentes como vítimas, é nessa temática que o potencial desse público como sujeito político é mais evidenciado, ainda que pontualmente, por meio de cobranças ao Estado para a erradicação desse tipo de trabalho infantil.

É também acerca desse tema que os jornais assumem uma postura de maior protagonismo em relação ao enfrentamento do TID, especialmente O Liberal, que possuía uma parceria institucional com o Cedeca-Emaús..$^{18}$ De acordo com a diretora administrativa das ORM, Rosângela Maiorana, em entrevista à Andi, o objetivo era "mobilizar o setor privado, incentivando a criação de vagas de primeiro emprego para as meninas maiores de 16 anos, e conscientizar a sociedade de que esse tipo de trabalho não pode ser tolerado". (VIVARTA, 2003, p. 123) Corroborando esse posicionamento, encontramos dois editoriais em $O$ Liberal sobre o TID. O primeiro é uma nota editorial que acompanha a matéria "Cedeca lança campanha de conscientização e denúncia”, publicada em 18 de março de 2004, e comenta os novos desafios a serem enfrentados:

18 Essa parceria foi ressaltada como um bom exemplo de engajamento da mídia no enfrentamento ao TID na pesquisa "Crianças Invisíveis: o enfoque da imprensa sobre trabalho infantil doméstico e outras formas de exploração", realizada pela Andi (VIVARTA, 2003, p. 123): "Um dos bons exemplos de enfrentamento do setor privado em relação ao problema vem justamente de uma organização de comunicação, a Rômulo Maiorana, que compreende os jornais O Liberal e Amazônia Jornal, a Rádio Liberal e a TV Liberal, afiliada da Rede Globo no Pará". 
É um passo ainda tímido, mas foi alcançado com muitas dificuldades, parcerias e voluntariado, como provam os dentistas que ajudam meninas a sorrir. Na segunda fase, a campanha coloca o dedo na ferida da sociedade, ao pedir que ela, de uma vez por todas, não considere mais natural esse tipo de exploração e mais, denuncie o explorador.

O grande desafio será, então, a mudança cultural, um processo difícil de se levar a cabo com a urgência que essas crianças precisam. Somente a mobilização e o envolvimento de quem repudia essa situação poderão ajudar a concretizar os sonhos dessas meninas. (O LIBERAL, 18/03/2004, grifo nosso)

O discurso do jornal dá a ver a necessidade de construção de solidariedade, como uso particular de power with. Nesse contexto, devemos compreender solidariedade como a habilidade de um grupo em agir em conjunto sob um terreno compartilhado de ação com o propósito de combater estruturas e/ou relações de dominação. (ALLEN, 1998, 2000) Assim, o editorial convoca os cidadãos que repudiam o TID a participarem da movimentação política para tornar concretos os sonhos de meninas envolvidas com essa prática e para que a cultura que alimenta o TID seja enfrentada. No entanto, o modo pelo qual o jornal faz essa convocação alija as afetadas como sujeitos políticos desse processo porque são posicionadas apenas como beneficiárias da ação em vista, não como pessoas que tomam parte na luta.

No outro editorial, publicado em 18 de junho de 2004, o foco do discurso do jornal é denunciar as condições nas quais o TID acontece e ressaltar a criminalização da omissão da sociedade em relação ao problema:

Sem que seja possível uma fiscalização oficial, o trabalho infantil, silenciosamente praticado no recesso de muitos lares, é o lado perverso da própria família ou do que restou do grupo familiar, que, para evitar mortes prematuras, distribui crianças e adolescentes por outras famílias para trabalharem domesticamente.

Nas atuais condições por que passa a sociedade, difícil é acabar com o trabalho infantil, porque depende da consciência moral de um adulto que, pela indiferença ao problema, torna-se omisso. O que já é outro crime. (O LIBERAL, 18/06/2004) 
São apontadas pelo discurso do jornal, diferentes causas que contribuem para a manutenção do TID: a inexistência de fiscalização por conta da inviolabilidade dos lares; a aceitação moral dessa prática, que faz com ela seja encarada com normalidade (ou indiferença) pela sociedade; e a situação de grave pobreza dos pais que, segundo o jornal, para manter a sobrevivência da família, distribuem os filhos e os encaminham ao TID. Ao produzir uma equivalência entre a indiferença ou a falta de ação a um crime, o texto apela à consciência do adulto para que seja possível combater essa prática. Novamente, quando o jornal ressalta a necessidade de construção de solidariedade e ações de contra o TID, às meninas e mulheres afetadas, é atribuído um lugar de passividade.

O componente cultural do TID também é apresentado pelos jornais como uma das principais causas de sua manutenção. Uma das fontes que ressalta o caráter cultural do TID é o então governador do Estado, Simão Jatene. Durante uma visita da Caravana Nacional Contra o Trabalho Infantil, que percorreu, em 2004, todos os estados brasileiros, com apoio do Unicef e da OIT, dois adolescentes entregaram uma carta sobre a realidade do trabalho infantil no Estado e um termo de compromisso que deveria ser assinado pelo chefe do executivo estadual. No Pará, uma das adolescentes que levou a carta havia sido trabalhadora doméstica e estava sendo atendida pelo Petid. O título da retranca que comenta o discurso do governador é "Questão cultural precisa ser eliminada, diz Jatene”:

[O governador] Disse que o problema do trabalho infantil é da competência de todas as esferas governamentais e da sociedade em geral, mas que o problema surge mais grave ainda porque trata-se [sic] de uma questão cultural. 'Chegamos ao ponto em que muitas vezes o trabalho infantil assume o caráter da naturalidade e é aí que as coisas de fato se complicam. A conotação cultural dessa tragédia precisa ser eliminada'. (DIÁRIO DO PARÁ, 01/10/2004)

Apesar de ressaltar a necessidade de uma política conjunta entre todas as instâncias de governo para enfrentar o TID, o destaque dado pelo governador é para a conotação cultural dessa prática. Essa foi a única vez, nos dez anos de cobertura, que um governador ${ }^{19}$ foi diretamente questionado sobre o TID. Ainda

19 Um vice-governador também foi chamado a se pronunciar sobre o TID em uma matéria de O Liberal, publicada em 13/06/2007, sobre a situação do trabalho infantil no estado. Ele foi ouvido durante uma 
assim, a fala dele reforça a responsabilização difusa por esse problema, na medida em que culpa a cultura (de um modo genérico) pela reprodução do TID.

Quase dez anos após aquela Caravana, Janete atualmente governa o Pará e pouco poderia dizer sobre o que foi feito para cumprir a promessa que fez naquele momento: "A gente sempre faz menos do que pode fazer. Estou honrado com a presença de vocês [adolescentes] e prometo que o Jatene fará tudo que puder para cumprir o compromisso que me trouxeram hoje", disse [o governador]. (DIÁRIO DO PARÁ, 01/10/2004) Não há, nem por parte das organizações sociais que lutam contra o TID nem por parte da cobertura jornalística, um questionamento sobre essas ações e o incentivo para que o governador mantenha-se responsável (accountable) em relação ao combate ao TID no estado.

Na mesma matéria, merece destaque, ainda, o modo como o lugar de fala da menina trabalhadora doméstica foi construído como um sujeito político que, além de não ficar restrita à vitimização, não se intimida frente ao governador do Estado para lutar em prol de uma causa que considera justa:

Letiane [14] leu um discurso bem elaborado onde [sic] apresentou dados sobre o trabalho infantil no Pará e pediu para fossem incrementadas mais políticas públicas para o setor . [...] Após o seu discurso, $e$ num improviso que surpreendeu, lembrou os tempos em que, como empregada doméstica, cuidava 'dos filhos dos outros sofrendo humilhações'. 'As crianças precisam estudar e brincar para crescerem felizes e sadias. Só assim elas terão condições de enfrentar a vida', disse a adolescente Letiane. (DIÁRIO DO PARÁ, 01/10/2004, grifo nosso)

Seguindo o encadeamento narrativo da reportagem, era esperado que a adolescente, que falaria ao governador durante a visita da Caravana, fizesse um discurso bem elaborado e bem informado sobre o trabalho infantil no Pará, já que estavam por trás dela, organizações sociais como o Cedeca-Emaús e Unicef. No entanto, a adolescente quebra aquele roteiro do que era esperado dela e resolve fazer uso da palavra durante o encontro para falar de si e do que considera necessário para que meninos e meninas tenham condições de crescer na vida.

audiência pública, convocada pela Assembleia Legislativa, para a repactuação do PETI no Estado, realizada no Dia Mundial de Combate ao Trabalho Infantil (12/06). 
Assim, estimula a construção de solidariedade e participa da construção de um terreno comum de atuação contra o TID.

Também de modo pontual na cobertura, é dado espaço de fala à presidente da Federação Nacional das Trabalhadoras Domésticas (Fenatrad), Creuza Oliveira, na notícia "Domésticas se unem contra o trabalho infantil doméstico no Brasil”, publicada em O Liberal, no dia 27 de abril de 2009, definido como dia da empregada doméstica:

\footnotetext{
'Nossa luta vai além dos direitos trabalhistas. É algo mais amplo que faz parte da luta contra a discriminação de mulheres, contra o preconceito racial, contra a violência doméstica e contra a exploração das crianças e dos adolescentes', destaca a presidente da Federação Nacional das Trabalhadoras Domésticas (Fenatrad), Creuza Maria de Oliveira, no Dia Nacional de Combate à Exploração do Trabalho Infantil Doméstico.

A Fenatrad estima que mais de 470 mil adolescentes e até crianças brasileiras estão trabalhando em serviços domésticos. 'É um tipo de serviço que acaba sendo alvo de exploração, porque impede essas crianças de estarem na escola. Além disso, elas têm uma remuneração menor que a prevista em lei'. (O LIBERAL, 27/04/09)
}

Trata-se da única matéria dentre os textos analisados que atribui a luta contra o TID às próprias empregadas domésticas, embora representadas por uma entidade de classe. Ainda assim, os detalhes dessa luta e os modos como ela se realiza não são apresentados. Apenas há referência à estimativa da quantidade de crianças trabalhando e a inclusão do TID entre outras demandas trabalhadas pela Fenatrad. De modo geral, representantes do Sindicato das Trabalhadoras Domesticas de Belém e Ananindeua e da Fenatrad só foram ouvidas em três momentos, o que correspondeu a 3,1\% do total de fontes, sendo que duas matérias eram alusivas ao Dia da Empregada Doméstica, como a que apresentamos, e uma discutia especificamente o TID. Nessa última, a participação do Sindicato se restringiu ao comentário sobre denúncias que vinha recebendo dessa prática. Mesmo se tratando de associações institucionalizadas e com potencial de transformar assuntos enraizados na sociedade em questões políticas (HABERMAS, 2003; WARREN, 2001), não tiveram um papel ativo na discussão pública sobre o 
TID. A nosso ver, esse é mais um elemento que contribui para confirmar nossa avaliação de que, em geral, considerando todas as temáticas, meninas e mulheres trabalhadoras e ex-trabalhadoras infantis domésticas foram posicionadas, sobretudo, como vítimas na cena pública. E o conteúdo e os lugares políticos de fala nesse espaço foram mobilizados e ocupados, majoritariamente, por agentes de advocacy autoautorizados e especialistas.

PERCEPÇÕES SOBRE RESPONSABILIDADE PELO TID NOS GRUPOS FOCAIS

Considerando os sete grupos focais examinados, foram apontados como principais responsáveis pela existência e manutenção do TID os pais e as próprias meninas trabalhadoras, seguidos pelo Governo, pela "necessidade" e pela sociedade de modo geral. As entrevistadas mais jovens tenderam a atribuir responsabilidade a si próprias pela inserção no TID, enquanto que as mais velhas atribuíram responsabilidade principalmente aos pais e ao governo.

No grupo das adolescentes do Projeto Social, a culpa pelo TID é individualizada. Segundo as entrevistadas, a menina procura emprego porque quer ter condições de comprar "suas próprias coisas", de modo a não ficar completamente dependente dos pais, que interferem diretamente sobre em que a adolescente pode ou não pode gastar dinheiro:

Moderadora: E me digam uma coisa, por que esse tipo de trabalho acontece? Por que meninas têm que fazer trabalho de casa, tem que trabalhar como babá? Por quê?

Michelle: Ah, porque na maioria das vezes ela quer ter as suas próprias coisas. Na maioria das vezes nossa mãe dá um dinheiro, assim... Mas não é aquilo que a gente quer. Eu quero passear, não tem dinheiro. Ah, vou trabalhar porque, eu trabalhando, eu vou ter o meu dinheiro ali e vou fazer o que eu quiser com meu dinheiro. Na maioria das vezes, elas [as mães] falam: 'Ah, vai trabalhar para você ter o seu dinheiro, não sei o quê....'

Alicinha: E tem gente que ainda joga na cara: 'Ah! você não trabalha, está dependendo de mim, vai fazer o que eu quero a hora que eu quiser'. Aí, a gente tendo nosso dinheiro para comprar nossas coisas, o que puder também ajudar a nossa mãe, pra gente poder dar também, para não ter ninguém jogando na nossa cara que a gente não faz nada, que é tudo vagabunda e vadia. 
Michelle: E na maioria das vezes, assim, eu tinha uma amiga, ela morava em um interior, assim. Aí ela veio para cá. Na maioria das vezes, as pessoas de interior pensam muito na família: 'Ah, vou trabalhar para Belém por que lá eu vou ganhar dinheiro, vou poder dar dinheiro para a minha mãe', e na maioria das vezes não é assim. Eu conversava muito com ela e ela me falava que a mulher explorava muito ela, porque ela queria tudo na hora certa... Sabe quem é?

Alicinha: É aquela que estudou com a gente.

Cris: É aquela loira.

Michelle: Aí ela falava: 'Ah! Porque eu quero ir embora, que eu me arrependo de ter saído da minha família'. Falava que passava necessidade. Na verdade, eles enganam de fato: 'Ah! Vou te dar tal, tal vou te dar isso e mais alguma coisas'. Por exemplo, ele te dá um tamanco ele vai te dar $\mathrm{R} \$ 100,00$ (cem reais) mais as coisa. Ele comprou o tamanco, mas o dinheiro de $\mathrm{R} \$ 100,00$ (cem reais) está descontado no tamanco. Então, na maioria das vezes você nem vê a cor do dinheiro!

Moderadora: E vocês, o que vocês acham que levam meninas para o trabalho doméstico?

Lecka: Depende da situação da família, da necessidade que estão passando. [...] Michelle: Nossa família. A própria família da menina, mesmo: mãe, pai. É porque, assim, leva muito pela cara. Por aquele lado do que quer... quer tudo, quer que seja tudo na hora. Vai procurar um trabalho, arrumar um emprego. Na maioria das vezes os familiares... [...]

Alicinha: É isso que leva às vezes a adolescente arranjar um trabalho e até sair de casa mesmo.

Michelle: E entrar até no mundo do crime, roubar que é a maneira mais fácil de conseguir as coisas

Lecka: De conseguir dinheiro é a maneira mais fácil. Pode ser a maneira mais fácil, mas também uma hora é pego. (PROJETO SOCIAL, grifo nosso)

Apesar de, num primeiro momento, as adolescentes chamarem para si a responsabilidade pela inserção no trabalho doméstico, ao longo do processo de interação do grupo, elas revelam matizes das relações de poder envolvidas nessa decisão e, de certo modo, compartilham essa responsabilidade com os pais. A partir desse contexto, elas destacam que, por meio do trabalho, podem alcançar certa autonomia, que permitirá escolher onde e como gastar o dinheiro conquistado. Sob outro viés, a entrada no trabalho doméstico é vista ainda como uma forma de se livrar do peso da dominação patriarcal. Em ambas as perspectivas, 
predominam relações de power to propiciadas, segundo elas, pela inserção no trabalho doméstico, porém, fortemente atrelada a essa vontade de ter as próprias coisas, está o desejo de não ser humilhada e não ter suas ações restringidas pelos pais, o que revela um forte componente de power over, que participa da decisão entre trabalhar ou não como doméstica.

É messe sentido que a responsabilidade também é jogada para a família. Relevante observar que, ao longo dos grupos focais, percebemos referências distintas aos pais e às mães das meninas domésticas. Em geral, elas se referem preponderantemente à mãe: a mãe que cuida, que é rígida, que exige compromisso com o trabalho na roça, de quem sentem saudades, que dá dinheiro, a quem pensam em ajudar com o retorno financeiro do TID. O pai, na maior parte das discussões, não é citado, provavelmente por ser ausente na vida de boa parte das entrevistadas. Quando aparece, assume a função de reprodutor de lógicas opressivas de gênero, ao exigir que só a filha cuide dos afazeres domésticos na própria casa, por exemplo, ou ainda como sujeito a quem a menina deve absoluta obediência.

Apesar de considerarem, em alguma medida, que, à primeira vista, o TID pode estimular o empoderamento, Michelle ressalta que nem sempre as promessas relativas ao valor a ser recebido pelo trabalho doméstico são cumpridas. Mesmo assim, as adolescentes, em geral, indicaram que o TID seria uma alternativa possível de conseguir algum dinheiro em contraposição a ações criminosas (“pode ser a maneira mais fácil, mas também uma hora é pego”, afirmou Lecka), por mais que concordem, como vimos anteriormente, que o TID não é um bom caminho profissional a ser seguido.

Embora o foco da atribuição de responsabilidade seja individual ou familiar, quando perguntadas sobre o que pode ser feito para evitar que crianças e/ ou adolescentes trabalhem como domésticas, elas ampliam a perspectiva para englobar governos e organizações sociais:

Moderadora: E me digam mais uma coisa, já que vocês pensam em exercer outras profissões e não o trabalho doméstico. Como é que vocês acham que a gente pode mudar esta situação? Tirar as meninas do trabalho doméstico.

Erizinha: Colocar mais projeto.

Michelle: Colocar mais projetos, mais recursos para ganhar bolsas, um dinheirinho assim... 
Lecka: Que não seja muito, mas que pelo menos dá para ajudar. (PROJETO SOCIAL)

A maneira que elas encontram de solucionar o TID é a existência de projetos sociais que ofereçam bolsas para que as meninas possam ter alguma renda e, se necessário, ajudar à família. A proposta que apresentam é bem próxima da realidade vivenciada por elas. Em razão de serem beneficiadas por um projeto social, elas acreditam que esse pode ser um bom caminho para combater o TID, desde que esteja vinculado ao recebimento de uma bolsa, um "dinheirinho" para poderem gozar de relativa autonomia em relação aos pais e mesmo ajudá-los no pagamento de despesas. Essa política seria uma forma de empoderar as adolescentes de modo que não precisassem realizar serviço doméstico em casas de família. Percebemos, contudo, que há um déficit informacional grande sobre as políticas públicas voltadas ao público jovem. Ou seja, elas apresentam uma ideia intuitiva sobre como acabar com o TID, mas demonstram também certa acomodação por não procurarem saber quais os programas já existentes e como participar deles.

No grupo "casa da patroa”, a responsabilidade pela entrada no TID também foi apontada como sendo individual:

Moderadora: E quem vocês acham que são os responsáveis? Pelo fato de meninas trabalharem desde cedo ao invés de brincar ou de fazer outras coisas?

Nanã: Quem são os responsáveis?

Moderadora: É. Tem algum responsável por isso assim?

Maria: Olha, no meu caso eu até digo que a responsabilidade é minha, porque pela minha mãe eu não estava aqui, eu estaria lá do lado dela. Mas eu via, assim, que muita das meninas que estão lá [em Curupu - MA] hoje, o que elas fazem lá é só ter filho e estão na farra, entendeu? E eu preferi vir trabalhar na casa dos outros para eu ter as minhas coisas, ter os meus estudos, entendeu? Com dificuldade. Eu preferi vir para cá do que ficar lá, mas a responsabilidade é minha porque por ela eu não estava mais aqui, eu estaria lá junto dela. Só que uma aposentadoria não dá para me manter, porque eu quero comprar isso, eu quero comprar roupa, eu quero ajeitar o meu cabelo e esse dinheiro não dá. Então eu preferi vim para cá, para ganhar o meu dinheiro e comprar as minhas coisas. [...]

Carol: Essa pergunta é meio... É assim para ter um responsável, não é? 
Moderadora: É assim, tem? Eu estou perguntando para vocês: tem algum responsável? Se tiver, quem é? De quem é a responsabilidade por meninas começarem a trabalhar?

Nanã: Eu acho que assim... Para as meninas, hoje em dia, como muitas coisas mudaram, eu acho que a culpa também é do governo, porque se o governo investisse em projetos, em estudo e assim para criar emprego e renda para as famílias, talvez muitas crianças que hoje são escravizadas no Brasil não seriam. Se o governo federal criasse um projeto, criasse alguma coisa para que todas as crianças fossem para a escola, e porque no futuro seriam adultos bem formados que tinham estudo e tinham emprego para que não deixassem que os seus filhos saíssem desde cedo para trabalhar na casa dos outros.

Maria: É. Também tem isso, mas assim... Se lá tivesse todas essas coisas que a gente está falando, nenhuma da gente estaria aqui, coisa que não tem. Não tem, nem os estudos de lá [Cururupu - MA] não prestam, porque quando eu vim de lá pra cá, eu sai de lá eu estava fazendo a quinta série. Quando eu cheguei aqui, quando eu comecei a estudar aqui, eu não tinha noção de nada, porque tudo era diferente. Porque se tivesse um estudo, se tivesse computação, umas coisas que a gente pudesse estar lá, ao invés de estar em farra, em negócio de estar arrumando namorado, eu acho que a gente não saia de perto da nossa família para vim para perto das pessoas que a gente nem conhece, que a gente nunca nem tinha visto na vida. [...]

Carol: É [risos]. Mas têm pessoas que optam, no meu caso, eu que quis vim para cá, minha mãe não me obrigou 'vai', não, eu quis para eu conseguir algo melhor, em busca de algo melhor. Mas tem alguns pais que eles obrigam os teus filhos a irem trabalhar mesmo. Tem uns que largam as pessoas na rua, não é? Tem pais que mandam os teus filhos para a rua trabalhar. É muito difícil, sim. (CASA DA PATROA)

Enquanto Maria e Carol atribuem a si a responsabilidade pela inserção no TID, Nanã culpa a ineficácia das ações do Estado em garantir condições adequadas para o fortalecimento da família. Desse modo, a participante contribui para a construção de um cenário mais abrangente a partir do qual o horizonte de expectativas de adolescentes pobres em municípios do interior é bastante reduzido. Há, portanto, um contexto opressivo mais geral, que não se refere à relação de power over entre sujeitos, porém age sobremaneira para constranger e limitar as escolhas possíveis para as meninas envolvidas no TID. Frente a esse proble- 
ma mais estrutural, o Estado deve formular políticas que visem à garantia de direitos sociais e à redução das graves desigualdades em que vivemos no Brasil. (CASTANHA, 2002; LAVINAS, 2012; RICHTER; SILVEIRA, 2012)

Em uma direção argumentativa bastante distinta, Carol reafirma que a entrada no TID foi resultado de uma decisão individual em busca de realizações. A própria pergunta que faz à moderadora - "Essa pergunta é meio... É assim para ter um responsável, não é?” - demonstra que, para essa participante, o correto não seria pensar em culpa ou responsabilidade, mas sim entender o TID como uma opção da adolescente.

Por um lado, podemos entender a autorresponsabilização pela inserção no TID como o indício de uma percepção estreita da realidade, incapaz de reconhecer as operações de poder que agem de modo tácito. Assim, culpa individualizada seria resultado de um processo de dominação que manteria a ilusão da igualdade de oportunidades e justificaria a desigualdade por meio da meritocracia. (SOUZA, 2009)

Por outro lado, desconsiderar a capacidade de agência e de decisão dessas meninas e mulheres que afirmam terem ido para as casas de família porque queriam buscar um futuro distinto do que era esperado delas em seus municípios pode obscurecer tentativas power to, que se relacionam à superação de situações ou contextos opressivos ou à perseguição de projetos de vida. (ALLEN, 1998; 2000) No entanto, não podemos supervalorizar essa perspectiva, na medida em que as condições estruturais que limitam o desenvolvimento de crianças e adolescentes nos seus municípios participam ativamente da percepção sobre as possibilidades de escolha que possuem de tal forma que se Carol tive seus direitos garantidos no lugar em que vivia, poderia não ter escolhido, como opção para "conseguir algo melhor", o TID.

No grupo das mulheres mais velhas, a discussão acerca da responsabilidade restringiu-se aos pais e, principalmente, às mães:

Moderadora: E me digam uma coisa, por que vocês acham que acontece de meninas trabalharem em casa de família? Por que isso acontece?

Tati: Da mãe, não é? Porque a mãe manda as filhas para a casa dos outros, porque eu, sendo mãe, já sei como é, a base como é. Eu não vou mandar as minhas filhas para a casa dos outros, vou não... [...] 
Duda: Assim, a minha opinião a respeito dessas meninas irem para casa de família muitas das vezes é por culpa da mãe, por quê? Porque ela tem muitos filhos, não é? Aí, chega um momento que ela não dá conta de sustentar muitos filhos, aí ela começa a distribuir as crianças para irem morar com as famílias trabalhar, não é? E, às vezes, é para ganhar dinheiro, às vezes é só por roupa, calçados, estudo, não é? Eu acho que a maioria das vezes é culpa dos pais mesmo. (CIDADE DE EMAÚS)

De acordo com as participantes desse grupo focal, o encaminhamento de crianças e adolescentes para realização de serviços domésticos na casa de terceiros ocorre por culpa dos pais, que não têm recursos para sustentar todos os filhos, e permitem que eles se empreguem em casas de família, ainda que sem pagamento de salário. Trata-se de uma percepção que atribui maior parte da responsabilidade aos pais e acaba por desconsiderar o contexto social mais amplo que limita as oportunidades que teriam de sustentar suas famílias. Como afirmam Gomes e Pereira (2005, p. 360), “A pobreza, a miséria, a falta de perspectiva de um projeto existencial que vislumbre a melhoria da qualidade de vida, impõe a toda a família uma luta desigual e desumana pela sobrevivência”. Nesse sentido, em relação ao tema da responsabilidade, percebemos nesse grupo a dificuldade em perceber o pano de fundo social e desigual que motiva a concordância dos pais com a saída das filhas para trabalharem em casas de família.

As mulheres ligadas ao Sindicato procuraram explicar um pouco mais essa escolha de alguns pais:

Moderadora: E, dona Erika, me diga uma coisa, de quem a senhora e vocês acham que é a culpa? Quem é o responsável por vocês passarem por isso?

Erika: É o governo.

Fofa: $\mathrm{Eu}$ acho que é falta de conhecimento.

Erika: É. A falta de conhecimento e o governo.

Fofa: Até porque mesmo os nossos pais eram pobres e não tinham conhecimento, não tinha estudo.

Erika: Era tudo analfabeto. E ele não procurava estudar.

Zezé: E muitas vezes mamãe tirava a gente do colégio para ir trabalhar na roça. (SINDICATO I) 
Essas entrevistadas apresentam uma percepção mais ampla sobre as responsabilidades em torno do TID porque a falta de conhecimento que, segundo elas, leva os pais a encaminharem suas filhas para esse tipo de serviço é resultante de lacunas anteriores provocadas pela ausência de políticas assistenciais e educacionais para essas famílias, de tal forma que os pais consideravam, por vezes, mais vantajoso a criança e ou o adolescente aprenderem um ofício, uma profissão que pudessem seguir, do que frequentar a escola. Como afirma Fonseca (1995), nas classes mais baixas a criança é predominantemente vista como "adulto incompetente", o que faz com que os pais preocupem-se prioritariamente com suprir necessidades objetivas. Assim, a perspectiva é que o retorno esperado por meio da formação formal era pouco tangível e sua utilidade para a vida prática daquelas crianças, por vezes, era difícil de ser percebida pelos pais.

De maneira genérica, as adolescentes do "centro de formação" consideraram que a "necessidade" é a principal causa pela inserção de adolescentes no TID, somada à falta de oportunidades e às dificuldades enfrentadas pelas famílias.

Moderadora: E olha, eu queria saber o que vocês acham que leva a menina para o trabalho infantil doméstico em casa de família?

Lorrane: Necessidade.

Tatá: É dificuldade, necessidade.

Nati: Muitas vezes é a falta de curso profissionalizante e de um emprego, assim, né? (CENTRO DE FORMAÇÃO)

Num momento posterior do mesmo grupo focal, elas desenvolvem mais a resposta e enfocam, principalmente, a importância de o governo criar projetos e cursos profissionalizantes para as adolescentes, para que elas recebam um salário, mas trabalhem em uma atividade vista por elas como mais digna e promissora do que o serviço doméstico. De modo semelhante ao grupo "projeto social", as entrevistadas buscam exemplos próximos à realidade em que vivem ao enfocar a importância da profissionalização de adolescentes como estratégia para o enfrentamento ao TID. Durante a realização desse grupo, percebemos a atribuição de um posicionamento destacado, hierarquicamente valorizado, no contexto daquela comunidade, a adolescentes que fizeram cursos dessa natureza e atuam como aprendizes em empresas. 
No grupo "condomínio", o governo também é responsabilizado pelo TID, porém de modo distinto: seja por não dar condições para que a lei (ECA) seja cumprida, seja porque está acostumando mal os pais a partir de programas de transferência de renda, como o Bolsa-família:

Karla: E hoje em dia, em parte o governo tem muita culpa sobre isso. Os politicos porque eles fizeram uma lei que protege o adolescente, a criança de trabalho escravo, mas eles não dão suporte, não é? Para as famílias carentes, para manter as crianças no colégio. Às vezes tem mãe, família que tem esse negócio da bolsa família, tem pessoas que só dependem disso, não procura outra coisa.

Wanderléa: Até a mãe se torna a virar uma vagabunda. Com licença da palavra. Por que ela se pega a pegar só a aquele dinheiro. Aí ela não quer sair mais pra cá para trabalhar, ela só espera aquele dinheiro. Aquela data para receber aquele dinheiro e haja a fazer filho. Aqueles filhos vão crescendo e com o tempo vão virando tudo marginal, porque a mãe quer, a mãe esta ensinando, porque se ela deixou de trabalhar para comer só a custas do governo. Pera aí. Borá trabalhar, que ninguém vai morrer. É isso que eu acho errado.

Tamires: Porque é para ajudar os filhos e os pais se tornam vagabundos porque ficam esperando.

Karla: Eu acho que o governo tem muita culpa nesse caso sim, muito mesmo sobre esse negocio da lei proteger muito a criança, de não trabalhar. Porque na nossa época não tinha tanto ladrão como tem hoje, não é? Aí, a lei protege a criança de não trabalhar.

Participante: Na nossa época nem tinha.

Karla: Aí, não dá suporte para a criança, aí você vai no colégio, o colégio não presta. É cadeira caindo aos pedaços. Você hoje em dia no jornal...

Wanderléa: Os próprios alunos já se tornam vândalos, porque eles mesmo já destroem.

Karla: Aí, não tem um... Aí só vai para a aula. Às vezes não tem uma merenda. Às vezes a criança não tem o que comer em casa, vai para o colégio, às vezes até naquela ansiedade de comer alguma coisa no colégio. Tem criança que só se alimenta praticamente no colégio, não é? Aí, às vezes, vai vendo aquela situação, aí o que acaba acontecendo, vai roubar, não é? O governo não dá uma assistência para as famílias muito carentes, não é? E tem pessoas que já nem procuram trabalhar. (CONDOMÍNIO, grifo nosso) 
O cerne do argumento expresso pela discussão entre as participantes reside na ideia de que foi criada uma lei para proteger meninos e meninas do "trabalho escravo", mas não são oferecidas, pelo Estado, condições adequadas para que eles e suas famílias busquem alternativas. Sobre esse assunto, ao analisar as políticas sociais e a relação com o trabalho infantil, Castanha afirma: "Não basta ter uma legislação protetora. É preciso construir o estado protetor, a sociedade protetora e a família protetora, de forma suficiente para assegurar direitos e cidadania”. (CASTANHA, 2002, p. 115)

Desse modo, o ECA é considerado uma legislação avançada, em termos de proteção dos direitos da infância e da adolescência, porque considera meninos e meninas sujeitos de direitos em condição peculiar de desenvolvimento e determina que eles devem ser protegidos de toda a forma de exploração. (BRASIL, 1990) Contudo, como percebem as entrevistadas do condomínio, a abstração da norma quando se encontra com as situações concretas da vida de crianças e adolescentes mostra o quão sérias são as dificuldades para implementação. No caso em tela, as mulheres ouvidas ponderam sobre a eficácia de termos uma legislação que protege crianças e adolescentes do trabalho, já que na ausência de políticas de retaguarda, esses meninos ou meninas poderão entrar para marginalidade.

Segundo elas, políticas como o Bolsa-Família não cumprem esse papel de retaguarda porque criam dependência ("Até a mãe se torna a virar uma vagabunda") e fazem com os pais não busquem trabalho e esperem aquela renda para sustentar os filhos. Esse questionamento representa uma das principais objeções que políticas dessa natureza têm sofrido. A origem, segundo Lavinas e Versano (1997), remonta ao exemplo americano no qual políticas de bem-estar social que existiam desde os anos 1950 e 1960 (como vale-refeição e auxílios para mães solteiras) foram questionadas e acusadas no final da década de 1990 de criar uma espécie de "parasitismo social”. Segundo aqueles autores, "A conclusão - apressada - seria a de que o auxílio social alimenta o parasitismo, senão já teria levado os pobres a saírem da pobreza; se não saem é porque não querem”. (LAVINAS; VERSANO, 1997, p. 9) De modo complementar, Marques (2007, p. 242) afirma que "a imagem da mãe como preguiçosa reforça a ideia de que elas são responsáveis pelas próprias mazelas que as atingem”. Frente a esses discursos, mulheres beneficiadas pelo Bolsa-Família entrevistadas por Marques (2007) afirmam que o recurso repassado pelo Programa está muito distante de proporcionar "àquela vida boa". 
Outro ponto do argumento discutido no grupo focal é a incoerência entre proibir o trabalho e manter a escola sem condições de estimular o aprendizado das crianças aprendendo porque isso seria um caminho para marginalidade. Por essa razão, elas culpam o Estado por não fazer leis e não realizar políticas eficazes para ajudar as famílias de modo não dependente. Nesse sentido, a crítica se aproxima do que foi exposto pelos jornais sobre as responsabilidades que, por meio das falas de especialistas, questionam o foco desses programas na responsabilização de meninos e meninas, e não dos adultos, pelo sustento da família, na medida em que toda a lógica assistencial é construída com base na criança a partir dos condicionalidades exigidas para participação no Programa (matrícula e frequência escolar, calendário de vacinação atualizado, acompanhamento do desenvolvimento das crianças em postos de saúde, entre outros).

Essa crítica ganha importante formulação no estudo "Políticas sociais e oferta institucional frente ao trabalho infantil doméstico no Brasil”, de Castanha (2002) publicado pela OIT. Segundo a autora, frequentemente a escola é considerada um espaço de socialização, propício para a intervenção social, porém não foram criadas estratégias e práticas concretas e suficientes para que ela cumpra esse potencial. (CASTANHA, 2002) A respeito da avaliação dos impactos do Programa Bolsa-Família na redução do trabalho infantil, vários especialistas defendem que esse programa tem influência positiva na escolaridade das crianças e adolescentes, mas não faz com que as famílias abram mão do trabalho do delas. (FERRO, KASSOUF, 2005; KASSOUF, 2007)

Por fim, as participantes do grupo "condomínio", ao discutirem as responsabilidades pelo TID, apresentaram suas percepções sobre ambiguidades na construção de leis e políticas (por exemplo, proibir o trabalho infantil sem dar alternativas concretas a meninos e meninas) e ampliaram o escopo da discussão para lançar luz sobre o terreno complexo de desigualdades no qual a prática do TID está inserida.

Tensões nas perspectivas dos media e das afetadas sobre projeções de futuro e responsabilidades

Em síntese, os jornais trabalharam com dois discursos principais acerca do futuro relacionado ao TID. O primeiro focava nos prejuízos que esse tipo de trabalho ocasionava a crianças e adolescentes, principalmente na área da educação e 
das possibilidades de formação profissional. O segundo referia-se ao Petid como aquele que afiançava um futuro para adolescentes envolvidas no TID. Assim, as personagens das matérias pareciam só ter futuro se estivessem sendo atendidas por programas e projetos sociais. Contudo, não há matérias com questionamentos sobre a eficácia do Petid em lhes garantir isso. Nesse sentido, o fato de os media analisados terem abordado o TID prioritariamente do ponto de vista de organizações e atores sociais, inclusive como parceiro formal, no caso de o Liberal, não estimulou uma postura crítica em relação ao modo como o Petid estava sendo desenvolvido e sobre o impacto concreto na vida das atendidas. De modo geral, algumas poucas meninas foram entrevistadas diversas vezes em diferentes momentos da cobertura, o que limita mais ainda a percepção sobre o futuro transformado da maioria das meninas atendidas.

Quando se falava de futuro para essas adolescentes, assim como nas falas das mulheres dos grupos focais, o caminho era a educação. Entretanto, as poucas meninas beneficiadas pelo Petid noticiadas recebiam bolsa e participavam de momentos formativos (com foco em direitos, cultura, autoestima, para citar alguns) e, nesse sentido, teriam melhores condições de percorrê-lo do que as meninas e mulheres entrevistadas nos grupos. Ainda assim, quando se referiam ao futuro, a maioria das entrevistadas nos grupos focais mostrava-se crítica acerca das limitações do TID nesse aspecto e consciente que deveria buscar uma formação melhor (principalmente as adolescentes, as adultas jovens e as mulheres do Sindicato).

As mulheres do "condomínio" se mostraram parcialmente realizadas. Wanderléia, por exemplo, disse que alcançou "um pouquinho" de seu sonho de ser enfermeira ao trabalhar cuidando de idosos, e as outras demonstraram acomodação com o emprego que têm porque se sentem respeitadas. Já as senhoras do grupo "cidade de Emaús" pensaram, sobretudo, no futuro que desejam para as netas, bem distante das casas de família e bem próximo delas.

A partir do que observamos em todos os sete grupos, os sentidos que atribuem a "dar futuro" são baseados nas ideias de dignidade, legalidade e melhor remuneração pelo serviço que realizam, apresentando, de modo geral, assim como nos jornais, a incompatibilidade entre o serviço doméstico (considerado pouco digno) e o futuro que desejam, sendo que algumas reconheceram o TID como um "mal necessário" para chegar mais perto do que querem. A questão decisiva aqui é "como" elas pensam o futuro. Encontramos dois modos principais: 
como algo realizável, mas que está lá adiante; ou como algo que estamos sempre realizando. De um lado, o futuro é projetado, como porvir distante e aberto. De outro, há um futuro pragmático, desejado e perseguido no dia a dia. Isso, a nosso ver, compõe a dinâmica das relações de poder que ora cerceiam, ora abrem possíveis. A menina que insiste em estudar e a menina que não pensou nisso porque considera cedo demais lidam de modo muito diferente com a questão do futuro. Essas posturas geram implicações distintas para a configuração política do problema. Nesse sentido, agir no hoje vislumbrando mudanças futuras pode significar atuar para transformar práticas opressivas.

Sobre a repercussão da temática "responsabilidade" nos media, ganha destaque o envolvimento de O Liberal no combate o TID. Por meio de matérias jornalísticas e editoriais, o jornal apontou como responsáveis pela ocorrência de TID: a sociedade e a cultura, em razão da "naturalização" dessa pratica; e a consciência do adulto que alimenta o TID ou ignora o problema e não age para que mudanças aconteçam. As meninas foram posicionadas como vítimas e, assim, caberia à sociedade se engajar para mudar essa realidade, criando condições para que elas pudessem realizar os próprios sonhos. O engajamento para combater o TID, portanto, não passaria pelas afetadas, que apenas seriam contempladas ao final de uma cadeia de ações de enfrentamento e mudança da realidade do TID.

Quanto às autoridades ouvidas pelos media, um governador e um vice, de gestões distintas, pronunciaram-se uma única vez cada. E os contextos dessas falas eram, no primeiro caso, uma Caravana contra o Trabalho Infantil, financiada por organizações sociais e internacionais, e, no segundo, a assinatura de um termo de repactuação do PETI no Pará durante uma audiência pública na Assembleia Legislativa no Dia Mundial de Combate ao Trabalho Infantil. Percebe-se, assim, que essas autoridades de alto escalão somente apareceram nos media quando foram criados eventos construídos e chancelados por importantes organizações.

Durante o encontro da Caravana, o governador responsabilizou, em parte, o Estado pelo TID, mas também destacou como maior vilã a dimensão "cultural" dessa atividade. Ao se responsabilizar a cultura por práticas como essa, provocase uma distância significativa entre as possibilidades de resolução do problema e aquilo que efetivamente pode ser feito, nesse caso, por instâncias governamentais. Nessa perspectiva, dizer que um problema é "cultural”, já traz em si uma justificativa pela dificuldade de sua solução e ameniza a responsabilidade do 
Estado na sua efetiva consecução. Nesse sentido, a crítica social pode ganhar contornos de um "gesto ritual” (SOUZA, 2009), mas que não se concretiza em políticas e ações.

Na cobertura desse mesmo evento, percebe-se o posicionamento como sujeito político da adolescente, que não apenas leu uma carta sobre a situação do trabalho infantil ao governador, mas usou aquela oportunidade para tomar a palavra e pedir melhores condições para que crianças e adolescentes possam enfrentar a vida. Embora seja extremamente pontual na cobertura, esse gesto é relevante porque desloca a adolescente do encaixe no lugar de vítima do TID, como ocorreu de modo recorrente em outras temáticas analisadas, e provoca fissuras nesse quadro de inscrição dos sujeitos afetados na problemática do TID.

Nos grupos focais, as responsabilidades pelo trabalho infantil são abordadas principalmente de um ponto de vista individual. Ainda que Souza (2009) defenda que a individualização da culpa seja reveladora de relações de dominação, o modo como as entrevistadas discutem esse assunto e atribuem lugar a si próprias reforça, em certa medida, sua capacidade de agência, especialmente a de tomar decisões que afetem significativamente as suas vidas. (ALLEN, 1998, 2000; BIROLI, 2012) Embora não considerem o TID o emprego ideal, elas enxergam nele a possibilidade de resistir a pais opressores - ou mesmo ao simples controle dos pais - ou ainda de adquirir alguma autonomia que lhes permita poder comprar o que desejam e buscar outras formas de vida.

As mulheres mais velhas, contudo, restringiram a responsabilidade pelo TID aos pais, sem problematizar aspectos estruturais que alimentam essa prática. Já as entrevistadas do Sindicato colocaram essa situação de modo mais complexo ao explicar que faltava aos pais, conhecimento, e que isso seria resultado de conjunturas das quais eles não tinham controle.

O Estado também foi responsabilizado por parte das entrevistadas pela ocorrência do TID. O único grupo em que essa discussão não apareceu foi justamente o das mulheres mais velhas. Para as adolescentes, tanto do "projeto social" quanto do "centro de formação", entre as causas desse tipo de trabalho infantil está a ausência de projetos sociais e cursos profissionalizantes voltados para meninos e meninas. As jovens adultas do grupo "casa da patroa" destacaram a necessidade da criação de políticas de emprego e renda para as famílias. Já as empregadas do "condomínio" questionaram como o Estado determina a proibição do trabalho infantil sem oferecer retaguarda para tanto. Segundo elas, a partir desse 
contexto, o fato de não trabalhar e de não ter escola atrativa poderia encaminhar os adolescentes para a marginalidade. É pertinente observar que não se trata, simplesmente, do discurso segundo o qual o adolescente precisa trabalhar para não cair no mundo do crime. É mais do que isso, na medida em que, a partir de suas experiências concretas, elas verificam o paradoxo da ação do Estado entre a promulgação de leis de proteção e a falta de condições para que as crianças e adolescentes sejam, de fato, protegidos ou incentivados a construírem dignamente o caminho profissional.

No próximo capítulo, que é o de conclusão do livro, realizamos análises transversais dessas temáticas com objetivo de apreender como o jogo entre relações de poder atua na configuração política do TID tanto na perspectiva dos media quanto das afetadas. 